\title{
ECOLOGICAL RESTORATION OF THE WAIRIO WETLAND, LAKE WAIRARAPA: WATER TABLE RELATIONSHIPS AND COST-BENEFIT ANALYSIS OF RESTORATION STRATEGIES
}

\author{
BY \\ BRIDGET ANNE JOHNSON
}

A thesis submitted for the partial fulfilment for the degree of

Master of Science in Ecological Restoration

Victoria University of Wellington

2012 


\section{Abstract}

The world's wetlands are known for being highly productive environments and supporting significant numbers of fauna and flora species that rely on the wetland's primary productions for survival. However, they were historically used by humans for hunting and fishing, wetlands were considered wastelands, best used when drained and filled for agricultural, industrial and residential development. Despite now having a greater understanding of wetlands and their ecological importance, degradation of wetlands continues, mainly due to anthropogenic activities. Wetland restoration involves reconstructing natural sites that have been degraded or completely lost and re-establishing their functions and values as vital ecosystems. Important restoration components include control of invasive weeds, emphasis on the presence of locally native species and restoration of the hydrological component.

The Wairio wetland is part of the largest wetland complex in the southern North Island and supports a number of native flora and fauna, of national and international importance. Wairio wetland has been destroyed by the effects of partial draining, unnatural hydrological control, clearing of native forest, construction of Parera Road separating once joined wetlands and the establishment of invasive willow trees and agricultural grasses. The co-management by the Department of Conservation and Ducks Unlimited, commenced in 2005, has begun a positive shift for the wetland. However, issues still remain due to the majority of the wetland still being used for farming, so there is no continuity between the three fenced restoration stages; artificial hydrological flow and water storage; and established willow trees along the wetland boundary.

Most ephemeral wetland vegetation displays a strong pattern of zonation, through a sequence from open water to dry land, which is correlated in some way with the duration and periodicity of water inundation. This hydrosere reflects differences in the degree of adaptation to aquatic life of different plant species. Two studies are reported here, conducted in two areas at the Wairio wetland over two desiccation periods. The first study conducted during 2010/2011 at stage one, focused on determining the environmental conditions of peak abundance and limits to distribution of key native and exotic plant species along an environmental (hydrological) gradient. The second study, conducted in 2012 at stage three, further investigated the effect of topsoil removal on the plant community and was a comparison study with the initial study at stage one. Results indicated that the Wairio wetland plant communities display strong zonation patterns progressing from aquatic species, to turf communities, to exotic grass species. Over the two desiccation periods 
studied it was found that the introduced species most abundant in low soil moisture were common pasture grasses, especially yorkshire fog (Holcus lanatus), brown top (Agrostis capillaris) and tall fescue (Schedonorus arundinaceus) as well as purple clover (Trifolium pratense) and the high soil moisture invasive competitor was water plantain (Alisma spp.). We also found that topsoil excavation impacts the plant community; topsoil scraping in the high soil moisture areas leads to a more native dominated plant community, with the dominant species being water plantain (Alisma spp.) and Isolepis prolifera, but scraping in relatively low soil moisture areas encourages the exotic grass weed species to grow.

Wairio wetland on the Eastern shore of Lake Wairarapa has been adversely affected by anthropogenic activities since the 1960s. In 2005, Ducks Unlimited and the Department of Conservation signed a Land Management Agreement where Ducks Unlimited would commence the restoration of the wetland. Survival of trees planted during the first few years was variable. Here, I report on the design and monitoring of a large scale field experiment involving the planting of around 2,500 trees of eight native wetland tree species Dacrycarpus dacrydioides, Podocarpus totara, Cordyline australis, Olearia virgata, Pittosporum tenuifolium, Coprosma robusta, Coprosma propinqua and Leptospermum scoparium. The trees were subjected to different methods of site preparation and aftercare to determine the best combination of treatments for successful establishment of tree saplings. Treatments included the use or non-use of topsoil excavation, release spraying, weedmats, nurse trees (with two combinations of species) and different spacing between the nurse species. Survival and growth over the first six months was monitored. Preliminarily results showed survival of $O$. virgata and $P$. totara was influenced by surface water, but few immediate effects of treatments upon growth rates. Olearia virgata, however, grew best in wet areas that had been scraped free of topsoil or drier areas that had not been scraped. Monitoring over the next 18 months will give us a better understanding of which is the most costeffective combination of treatments. Early indications suggest high level survival under all treatments. 


\section{Acknowledgements}

I am extremely grateful to my supervisor, $\mathrm{Dr}$ Stephen Hartley, whose guidance, encouragement and support from start to finish has enabled me to develop a greater understanding of wetland restoration and statistical data analysis, thank you. It was an honour to work alongside the Wairio Wetland Restoration Committee; this study would never have been possible without their support. In particular, I would like to thank Jim Law, Tony Silbury (Department of Conservation Wairarapa), Don Bell (Greater Wellington Regional Council), Tony Faulkner (Greater Wellington Regional Council), Ross Cottle and Trevor Thompson. I am indebted to my family, friends, many of my colleagues and the volunteers who graciously assisted with field work, in particular my husband, Nathan Johnson; my parents, Bruce and Sue Read; Rose Bird; and Jeff Benson. I would like to thank those who have financially supported my studies Jim and Marilyn Law, the Wellington Botanical Society, the National Wetland Trust and, of course, Nathan. Lastly, I would like to thank the technical, administration and academic staff at Victoria University of Wellington for their assistance throughout my thesis year. 


\section{Table of Contents}

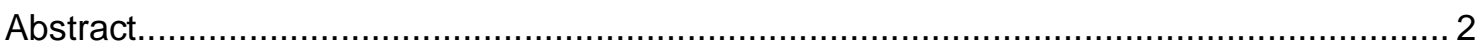

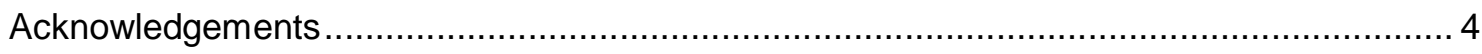

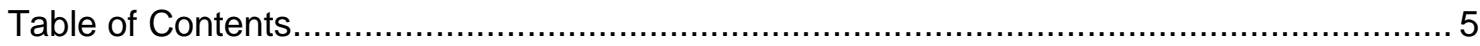

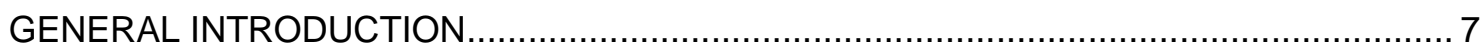

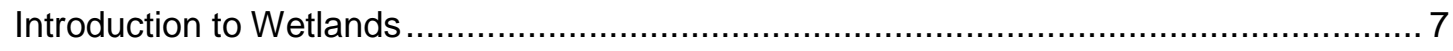

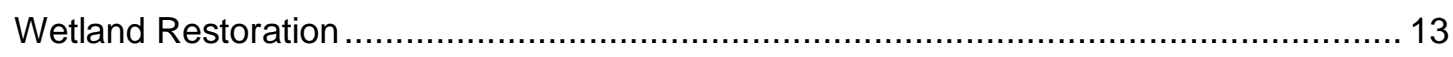

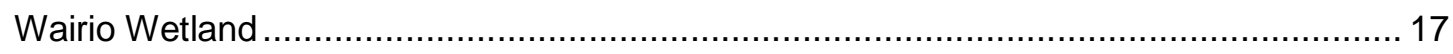

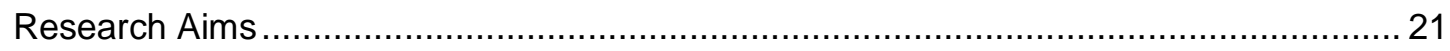

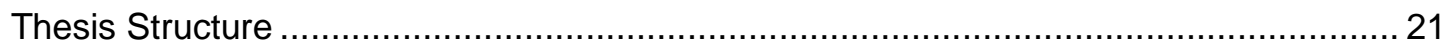

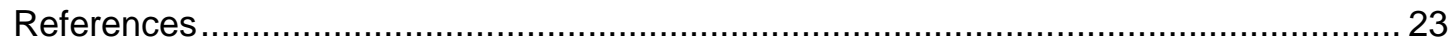

SPATIAL AND TEMPORAL PATTERNS OF PLANT COMMUNITIES DURING SUMMER DESICCATION AT A SEASONAL WETLANDS, SOUTHERN WAIRARAPA ..................... 27

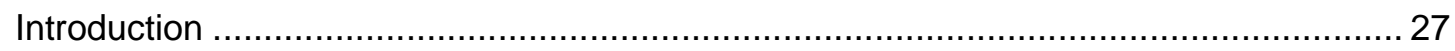

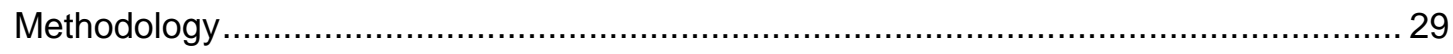

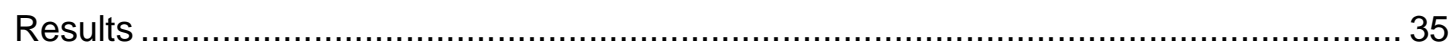

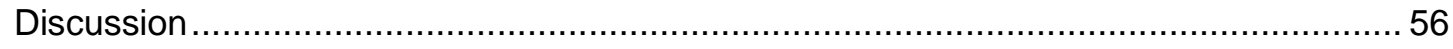

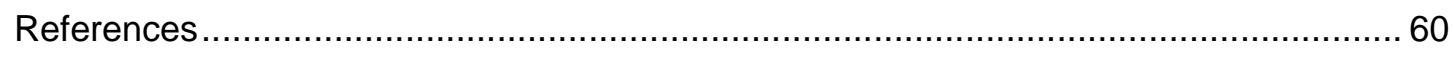

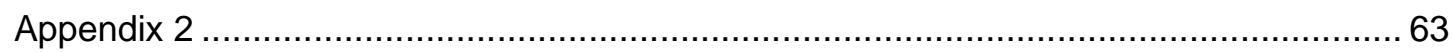

INVESTIGATION INTO THE PROCESSES INFLUENCING THE ESTABLISHMENT AND SURVIVAL OF NATIVE WOODY VEGETATION AT WAIRIO WETLAND ....................... 71

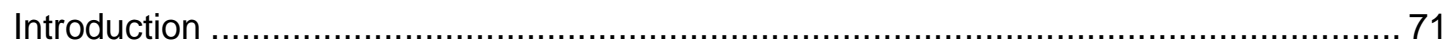

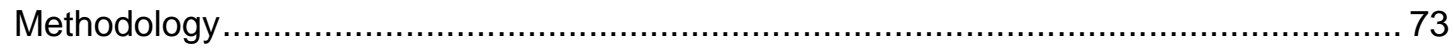

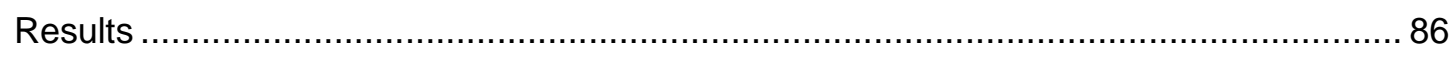

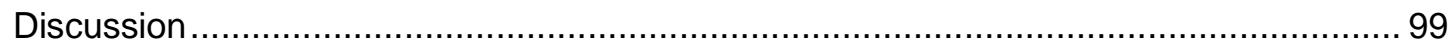

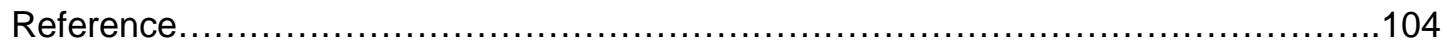

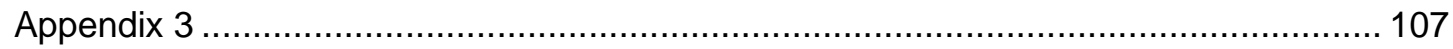




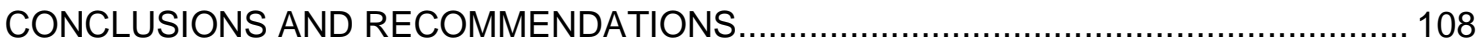

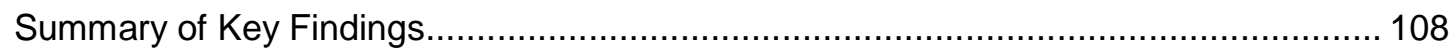

Restoration Recommendations for Wairio Wetland................................................. 110

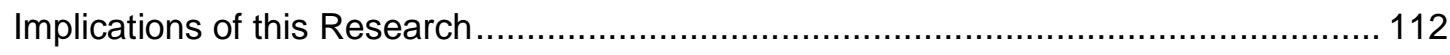

Summary of Recommendations for Current Practice ............................................. 113

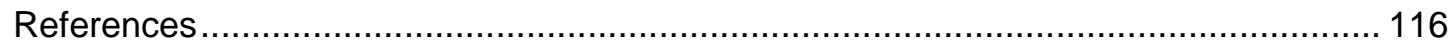

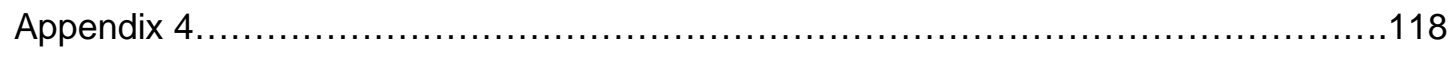




\section{GENERAL INTRODUCTION}

\section{Introduction to Wetlands}

\section{What are Wetlands?}

Wetlands are not truly aquatic, as they often have soil, but neither are they truly terrestrial, as they have standing water (Keddy, 2006). They form at the edge of terrestrial and aquatic environments, having characteristics of both (Gibbs, 1993). Wetlands are found where there is water, including saline coastlines; however, most are associated with fresh water systems. While they can be highly variable in appearance and species composition, inundation of water is their shared characteristic and the primary factor in controlling their environment and associated plant and animal life. They come in many different guises, including streams, swamps, bogs, lakes, lagoons, estuaries, mudflats and flood plains (Johnson and Gerbeaux, 2004).

\section{The Importance of Wetlands}

Wetlands are among the world's most productive environments (Navid, 1989). They support high concentrations of birds, mammals, reptiles, amphibians, fish and invertebrates (Knight, 1997), all which are dependent on the water and primary production for survival. Although 
historically used by people for hunting, trapping and fishing, recently wetlands were largely considered wastelands whose best use could only be attained through "reclamation projects" such as drainage for agriculture and filling for industrial, residential or agricultural development (Tiner, 1984). Much to the contrary, wetlands in their natural state provide a range of values and ecosystem services to society and with sustainable management they can fulfil an array of functions, such as ground water buffering and holding large quantities of biodiversity (Greeson, 1979; Gibbs, 1993; Gren et al., 1994). Our increased knowledge of these ecosystem services has facilitated adjustment of our anthropogenic dislike of wetlands. Attempts have been made at estimating the economic values of wetlands worldwide and it is in the order of \$US 70 billion each year (Schuyt and Brander, 2004).

Gren et al. (1994), presented primary and secondary values of wetland ecosystems in an attempt to improve the understanding of the importance of wetlands. Primary value refers to the development and maintenance of the ecosystem, where secondary values are defined as the outputs such as the functions and services generated by the wetlands. Case studies show that estimating wetland values can be improved by understanding the ecosystem functioning and only part of the value can be measured financially. Wetland benefits can be divided into three basic categories1) fish and wildlife values, 2) environmental quality values and 3) socio-economic values (Table 1) (Greeson, 1979). These wetland benefits are examples of secondary values. The plant cover of any wetland influences many of these values and, therefore, holds major value itself. 
Table 1 Major Wetland Values (modified from Greeson (1979) and DOC (2011)).

\begin{tabular}{lll}
\hline Fish and wildlife values & $\begin{array}{l}\text { Environmental quality } \\
\text { values }\end{array}$ & Socio-economic values \\
\hline $\begin{array}{l}\text { Exceptional habitats } \\
\text { supporting rich wildlife }\end{array}$ & $\begin{array}{l}\text { Chemical and nutrient } \\
\text { absorption }\end{array}$ & $\begin{array}{l}\text { Ground water recharge and } \\
\text { water supply }\end{array}$ \\
$\begin{array}{l}\text { Wabitat } \\
\text { Fish and shellfish habitat }\end{array}$ & Oxygen production & $\begin{array}{l}\text { Education and scientific } \\
\text { research }\end{array}$ \\
$\begin{array}{l}\text { Other wildlife habitat } \\
\text { Nutrient recycling }\end{array}$ & $\begin{array}{l}\text { Flood and erosion control } \\
\text { Pollution filter }\end{array}$ & $\begin{array}{l}\text { Hunting and fishing } \\
\text { Energy source (peat) }\end{array}$ \\
& Microclimate regulator & Aesthetics \\
& Aquatic productivity & Recreation and tourism \\
& & Agriculture and farming \\
& & Historical importance \\
\hline
\end{tabular}

\section{International and National Wetland Loss}

It has been estimated that since $1900,50 \%$ of the world's inland wetlands have been lost. The majority of this loss has occurred in the northern temperate zone, during the early 1900s. Though, since the 1950s swamp forests and mangroves have been increasingly destroyed. The primary cause of wetland loss worldwide is considered to be agricultural development (Gallant et al., 2007). It was estimated that $56-65 \%$ of existing wetlands had been drained for agriculture by 1985 in Europe and North America, 27\% in Asia, 6\% in South America and $2 \%$ in Africa (Zedler and Kercher, 2005). An international intergovernmental treaty, the 1971 Ramsar Convention, has assisted 160 countries to protect the most significant remaining wetlands (Zedler and Kercher, 2005; The Ramsar Convention on Wetlands, 2011). There are 1,952 wetlands on the Ramsar Convention International Importance list, which cover a total surface area of 1.9 million $\mathrm{km}^{2}$ (The Ramsar Convention on Wetlands, 2011).

A 2008 study estimated that wetlands historically covered 2.4 million hectares over New Zealand, almost $10 \%$ of the country (Hansford, 2011). Less than 250,000 ha have survived. 
Only $4.9 \%$ of the North Island wetlands remain, with $16 \%$ remaining in the South Island (Ausseil et al., 2007). The remaining wetlands continue to be threatened by agricultural practices and the presence of invasive plant species (Ausseil et al., 2007). However, the New Zealand public has an increasing respect for wetlands and the ecological value they hold, resulting in growing demand for restoration efforts (Campbell and Jackson, 2004). Historically, the majority of the research on New Zealand wetlands has focused on their role in the energy cycle and the fauna communities within the ecosystem (Sorrell and Gerbeaux, 2004). Currently, New Zealand has six wetland sites designated as wetlands of International Importance by the Ramsar Convention (Awarua wetland, Farewell Spit, Firth of Thames, Kopuatai Peat Dome, the Manawatu Estuary and the Whangamarino wetlands), covering a total surface area of 55,512 ha (The Ramsar Convention on Wetlands, 2011).

\section{Wetland Hydrology}

In wetlands, the field of hydrology examines the movement and storage of water and describes the hydrological inputs and outputs of a wetland and how it affects the soils and local flora and fauna (Campbell, 2010). A wetland's composition depends on hydrology, as it controls the transportation of nutrients in and out of the system, which affects the biodiversity structure (Rokosch et al., 2001). Small changes in the physical and chemical properties of a wetland's hydrology can significantly shift the ecosystem's productivity and plant composition (Mitsch and Gosselink, 1993). Human intervention has seen an increase in artificial control of water, resulting in extreme water tables, which either allows dry-land weeds to invade or creates prolonged flooding (Campbell, 2010).

\section{Wetland Flora}

Wetland plants can be characterised by vertical and lateral gradients (Van Coller et al., 2000), reflecting succession from open water to dry land. This hydrosere reflects differences in the degree of adaptation to aquatic life of different plant species. Factors such as substrate type, soil moisture and nutrient status vary along the gradients. The alternating wet and dry periods in wetlands naturally affect plant establishment from the seed banks by stimulating or inhibiting germination (Brock and Britton, 1995). Prolonged flooding or desiccation of the wetland ecosystem eliminates some species while favouring others (van der Valk, 1981). This has a significant effect on species composition of establishing plants (Casanova and Brock, 2000). The decline of wetland abundance and health has increased the magnitude of plant invasions (Davis and Pelsor, 2001). Once established, many invasive 
plant species can further exploit opportunities provided by anthropogenic disturbances and natural flood events (Davis and Pelsor, 2001; Richardson et al., 2007).

Among the various wetland types in New Zealand there are three typical wetland forests in New Zealand:

1) Swamp forests, which are seasonally flooded, are commonly dominated by Kahikatea (Dacrycarpus dacrydioides), New Zealand's tallest native tree.

2) Peatland forests, which develop in poorly drained regions experiencing low temperatures and high rainfall, allowing thick beds of undecomposed vegetation matter (peat) to build up. Silver pine (Manoao colensol) is the most common peatland forest tree.

3) Intertidal forests, which are dominated by the mangrove, Avicennia marina subsp. australasica and are formed in the sub-tropical north of New Zealand's North Island.

The majority of the peatlands are in national reserves, but swamp forests are scattered around private lands. (DOC, 2011).

\section{Wetland Fauna}

All wetland types provide unique habitats for a variety of fauna, both aquatic and terrestrial. Wetland birds and mammals are attracted to wetlands by the abundance of amphibians, fish, water-associated reptiles, invertebrates and plants (seed sources). Many of New Zealand's wetland fauna are native species, for example, fern bird (Bowdleria punctata), brown teal (Anas aucklandica), New Zealand dabchicks (Poliocephalus rufopectus), scaup (Aythya novaeseelandiae), paradise shelducks (Tadorna variegata), kokopu (Galaxias spp.), mudfish (Neochanna spp.), freshwater crayfish (Paranephrops spp.) and the green skink (Oligosoma chloronoton). New Zealand wetlands accommodate $30 \%$ of our total diversity of native freshwater fish and $22 \%$ of our total diversity of bird species. The New Zealand Wildlife Management Act 1993 protects the majority of the country's native wetland birds (Watts et al. 2010).

\section{Processes Damaging Wetlands}

The vital role wetlands play in maintaining the overall health of our ecosystem has become clearer over the past three decades (Thompson and Luthin, 2004). Human alterations have, either directly or indirectly, significantly influenced natural wetland processes (Richardson et al., 2007). Human activities have and continue to cause wetland degradation and loss in 
three main ways. Firstly, hydrological alterations, as any changes in hydrology can alter the soil chemistry and animal and plant communities. Secondly, pollution inputs, as although wetlands are adept at absorbing pollutants from surface water, there is a limit in their capacity to do so. Thirdly, native wetland plants become particularly vulnerable when subjected to grazing animals and invasive plants (United States Environmental Protection Agency, 2001) (Table 2).

Table 2 Major human activities causing wetland degradation (United States Environmental Protection Agency, 2001).

\begin{tabular}{lll}
\hline \multicolumn{1}{c}{ Hydrological Alterations } & \multicolumn{1}{c}{ Pollution Inputs } & \multicolumn{1}{c}{ Plant Damage } \\
\hline $\begin{array}{l}\text { Drainage for development, } \\
\text { farming and mosquito control }\end{array}$ & $\begin{array}{l}\text { Runoff from urban, } \\
\text { agricultural and mining areas }\end{array}$ & $\begin{array}{l}\text { Introduction of exotic plants } \\
\text { that compete with natives }\end{array}$ \\
$\begin{array}{l}\text { Deposition of fill material for } \\
\text { development }\end{array}$ & $\begin{array}{l}\text { Air pollution from cars, } \\
\text { factories and power plants }\end{array}$ & Grazing by domestic animals \\
$\begin{array}{l}\text { Dredging and channelling } \\
\text { streams for urban } \\
\text { development and flood } \\
\text { control }\end{array}$ & $\begin{array}{l}\text { Marinas, where boats } \\
\text { increase turbidity and } \\
\text { release pollutants }\end{array}$ & $\begin{array}{l}\text { Removal of vegetation for } \\
\text { peat mining }\end{array}$ \\
$\begin{array}{l}\text { Creation of dams to form } \\
\text { ponds and lakes }\end{array}$ & $\begin{array}{l}\text { Old landfills and dumps that } \\
\text { leak toxic substances }\end{array}$ & \\
$\begin{array}{l}\text { Diversion of flow to or from } \\
\text { wetlands }\end{array}$ & & \\
\hline
\end{tabular}




\section{Wetland Restoration}

Ecological restoration aims to repair human-mediated changes to the diversity and processes of ecosystems (Jackson, 1995). It generally involves reconstructing an ecosystem and returning it to a previous condition and commonly includes re-establishing species, structure and ecological functions that prevailed previously in the system (Van Diggelen, 2001). Complete ecological restoration is usually impossible at the landscape scale because of land use (and water use) conflicts and costs (Van Diggelen, 2001). Considering that human-mediated changes have interrupted multiple factors at a range of scales in wetland environments, innovative and realistic approaches are required in their restoration (Richardson et al., 2007). For optimal environmental outcomes, it has been argued that restoration ecology needs to be based on science (Clewall and Rieger, 1997; Winterhalder et al., 2004; Clewell and Aronson, 2006). Restoration ecology is becoming more sophisticated (Clewall and Rieger, 1997), turning the technique of restoration into a science integrating a broad spectrum of disciplines (Halle and Fattorini, 2004).

Restoration of any ecosystem can be expensive, thus making it important to design and implement all projects as effectively as possible to avoid wasting money. Many restoration projects, however, fail outright or fail to completely achieve the project's goals. Wetland restoration is no exception. A study completed by the United States Office of Energy Projects (2004) reported that the success of wetland restoration projects in the US ranged from $89 \%$ in the humid eastern areas to $32 \%$ in the dry western areas. The overall US national wetland restoration success was 65\% (313 wetlands). Failure was generally associated with improper hydrological conditions in the new wetlands (Mitsch and Wilson, 1996) and having less than $80 \%$ native plant cover (Office of Energy Projects, 2004). However, this number could be inaccurate, as many failed projects are never documented. Quality wetland restoration needs to involve careful planning, the setting of sequential, multistep goals and management of cost controllers (Palmer et al., 1997; Lewis, 2004). Lewis (2004) states the key to successful wetland restoration is to first determine the natural hydrology and plant populations in the given area. The restoration of these ecosystem features and the replication of a site's natural function stand more of a chance of success than artificially engineered systems. 


\section{Restoring the Hydrology}

Where water is the dominating force in structuring an ecosystem, as in wetlands (PlantyTabacchi. A.M., 1996; Shafroth, 2002), manipulating the abiotic components must be central to ecosystem repair (Ehrenfeld, 2000). The primary variables driving the distribution and abundance of biota in flood-prone wetlands are usually abiotic (Stanford, 1996). Restoring these areas typically requires the hydrological dynamics of the wetlands to be restored first (Vaselaar, 1997; Patten, 2001; Rood, 2003), as reinstating water can directly affect the relative performance of native and alien species (Levine and Stromberg, 2001; Sher and Chesson, 2002). Hydrological dynamics includes properties such as the seasonal timing, intensity and frequency of inundation.

Establishing natural hydrological flow is a key factor in all wetland restoration projects (Bedford, 1996; Rokosch et al., 2001). However, a significant issue with wetland restoration projects is the absence of knowledge surrounding the hydrological regime of wetlands (Rokosch et al., 2001; Campbell, 2010). Any intended hydrological changes made to the water flow should aim to reinstate natural flow rather than adding artificial damming structures (Campbell, 2010). Goals for restoring natural hydrological function can include improving the upstream water quality by removing stock, planting riparian areas, raising the water level to stop weed invasion or creating suitable habitat for native fish (Campbell, 2010). Where hydrological functioning can support the intended assemblage of species, biotic components, for instance vegetation structure and composition, can then become the focus of repair (Hobbs and Harris, 2001). There are some cases where a small number of highly influential, exotic plant species are the main environmental stressors (Richardson et al., 2007). Concentrated efforts to remove these species (or reduce their density), prevent their reinvasion and re-establish appropriate species constitute a plausible restoration project. This study does not focus directly on the effects of hydrological restoration, but there is need for follow up studies in the near future.

\section{Invasive Plants}

One of the most visual signs of human alteration to a wetland is invasive weeds. The invasion of wetlands by weeds is a major threat to its habitat values, as they can modify the structure or function of the wetland (Rea and Storrs, 1999), disrupt the natural flood regime (Government, 2011), out-compete native plants, alter fauna habitat and negatively affect positive restoration activities (Clarkson and Peters, 2010). Many wetland weeds have been deliberately introduced for agricultural or domestic gardens and then have escaped 
cultivation, infesting local waterways and wetlands (Government, 2011). Any wetland restoration project requires deliberate weed control (Clarkson and Peters, 2010). The type of control management used is dependent of the overall restoration goals. These generally fall into three categories containment, to restrict further spread; control, to reduce the weed population; and eradication, to eliminate the whole local population. Effective weed control will not only advance the survival of native plant species, but also provide wider benefits to the wetlands, for example, conservation of rare species, retention of ecosystem process and increased habitat for native fauna (Clarkson and Peters, 2010). The most troublesome wetland weeds in New Zealand are the crack (Salix fragilis) and grey willows (S. cinerea); they were introduced for bank stability, but they also block stream flow and outcompete many native plant species.

Revegetation is the most common type of wetland restoration project (Clarkson and Peters, 2010), as degraded wetlands require the re-establishment of a native wetland plant community (Brown and Bedford, 1997). Generally, this involves removing introduced weeds and replacing them with native plants. The goals of wetland revegetation projects typically focus on increasing biodiversity, functional or scenic values of the wetland site (Clarkson and Peters, 2010). Regardless of the revegetation goals, key steps have been developed by many local councils, private organisations and community groups worldwide, giving advice on how wetland projects can have a greater chance of success. However, most of this guidance is anecdotal and not in the formal science arena. The majority of the detail has been passed down through years of field experience, rather than tested proof.

\section{Social and Management Processes}

The United States Environmental Protection Agency has established realistic principles to guide wetland restoration (Table 3 ) that have been critical to the success of a wide range of wetland restoration projects worldwide. These principles apply to different stages in the life of a restoration project, from early planning to post-implementation monitoring. The principles focus on scientific and technical issues, but as with all environmental management projects, the local community and its perspectives should be valued. 
Table 3 Principles for the Ecological Restoration of Aquatic Resources, ordered along the life cycle of a project (United States Environmental Protection Agency, 2000).

\section{Principles for Ecological Restoration}

Establish site-selection criteria

Develop clear, achievable and measureable goals

Focus of feasibility

Design for self-sustainability

Work within the water/landscape context

Involve a multi-disciplinary team

Restore ecological integrity

Restore natural structure and function

Restore native species and avoid invasive species

Understand the hydrology of the site

Preserve and protect aquatic resources

Use reference sites

Address on-going causes of degradation

Monitor and adapt where changes are necessary

Anticipate future changes

Develop a long-term management plan

Coordination with the local community is important in building support for restoration projects and to ensure long-term protection of the restored area. Partnership with the community can add useful resources, financially and with volunteers for implementation, monitoring and technical expertise (United States Environmental Protection Agency, 2000; Parks et al., 2011). Without the partnership support, restoration projects may be delayed or even abandoned. Commitment to restoration projects needs to be long-term and requires serious attention to follow-up and monitoring. Short-term projects lacking social or political assistance are unlikely to succeed (Richardson et al., 2007). The long-term success of any restoration project will be largely tied to the community and financial support it receives. Community backing and volunteer participation can aid in the permanence and success of a project. In order to encourage public support, opportunities for community involvement need to be carefully considered prior to embarking on the project. Community involvement provides opportunities to educate the public and gain support for biodiversity recovery and 
ecological restoration. This participation will promote a sense of ownership and investment by the community that will bode well for the continuation of the project (Parks et al., 2011).

Wetland restoration can be complex and decision making needs to integrate a broad range of disciplines. It is essential that (to the extent that resources will allow) planning, implementation and monitoring of a project involves people with experience in the disciplines required, for example, integrating disciplines such as landscape, aquatic, wildlife and plant ecology, hydrology and even the social sciences (United States Environmental Protection Agency, 2000). National and local government agencies, universities and private organisations can provide expertise to ensure that restoration projects are based on educated information. A governing committee needs to negotiate, linking different agendas together to form a functional team, improving the overall effectiveness of the project.

\section{Wairio Wetland}

\section{Background}

The Wairio wetland is located on the eastern side of Lake Wairarapa, Wairarapa, New Zealand (Figure 1) and is part of the largest wetland system in the lower North Island. The wetland area is considered to be of international importance for flora and fauna as it supports rare birds and native fish and nationally threatened plant species (Airey et al., 2000). As earlier mentioned, wetlands were once considered wastelands best drained for agriculture, or industrial and residential development (Tiner, 1984). The Wairio wetland is an example of this mentality and practice. The Lower Wairarapa Valley Development Scheme (LWVDS) was successfully launched in 1960 and provided comprehensive flood control methods for the whole district (Robertson, 1991). Various schemes had been previously proposed since 1886, but had never come to fruition. However, many of these earlier initiatives were integrated into the LWVDS (Airey et al., 2000). The Wairio wetland was negatively affected by the activities of the 1960s' scheme, as it consequently saw Lake Wairarapa being partially drained, the shore regions being cleared of forest and sedges and willow trees planted for erosion control, resulting in an infestation in the wetland and the construction of Parera Road which separated Wairio from the adjacent Boggy Pond wetland (Airey et al., 2000). 


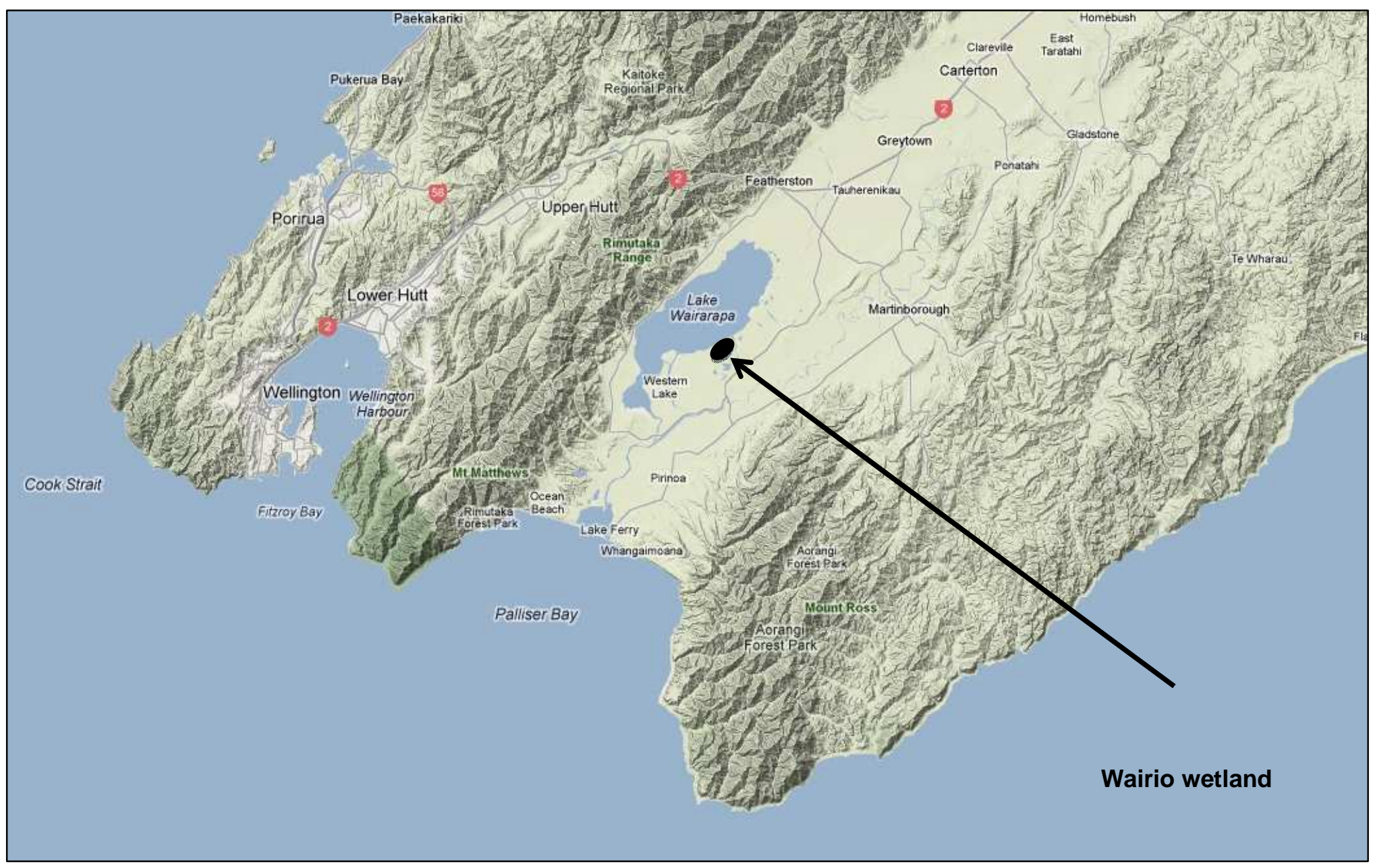

Figure 1 Map of Lower North Island, New Zealand, indicating the location of Wairio wetland (wetland not to scale). Map from google maps. 
A positive turnaround began during the 1980 s as awareness of the environmental effects of land development began to grow. The Conservation Act of 1987 gave 'stewardship' of the Wairio wetland area to the Department of Conservation (hereafter regarded as $\mathrm{DOC}$ ), with the objective to hold the land for conservation purposes. Currently, the Wairio wetland is managed by DOC and Ducks Unlimited (hereafter referred to as DU). In 2005 they signed a Land Management Agreement whereby DU would commence, in partnership with DOC, the restoration of the Wairio wetland. DU and DOC have partnered before, in the late 1980s, when they unsuccessfully attempted to re-flood the Wairio wetland (Ducks Unlimited, 2010).

\section{Hydrology}

Little is known specifically about the hydrology of the Wairio wetland. The eastern side of Lake Wairarapa slopes gradually from open water through zones of wetland plants to farmland (Airey et al., 2000). Water levels naturally fluctuate through rainfall and wind effects. However, they can be artificially controlled by the Barrage Gates which were constructed between 1971 and 1973 at the Ruamahanga River mouth into Lake Wairarapa (Airey et al., 2000). The issue of hydrology and its function in the wetlands will need to be addressed if the Wairio wetland restoration project is to succeed in the long term. Issues requiring solutions are the effects of artificial ponds, temporal sequences of water depths, magnitude and frequency of high water levels, restoration of natural hydrological regime across the whole catchment and how the water fluctuations affect native local flora and fauna.

\section{Flora}

At the Wairio wetland the remnant native trees are kahikatea (Dacrycarpus dacrydioides), cabbage trees (Cordyline australis), totara (Podocarpus totara), kowhai (Sophora sp.), pokaka (Elaeocarpus hookerianus), titoki (Alectryon excelsus) and matai (Prumnopitys taxifolia). The Wairio wetland region is a key habitat for native turf plant species. There are a number of these turf species along the natural and man-made lake and ponds that are nationally threatened and rare species, including Leptinella maniototo, Crassula ruamahanga, Carex cirrhosa, Pilularia novaezelandiae, Hypsela rivalis and Amphibromus fluitans (Common names in Appendix 2.1). Due to the surrounding agricultural land, the wetland is inundated with invasive weeds such as tall fescue (Schedonorus arundinaceus), yorkshire fog (Holcus lanatus), browntop (Agrostis capillaris), Glyceria maxima and water plantain (Alisma spp.). 


\section{Fauna}

The greater Lake Wairarapa wetland area is home to a number of birds, fish, insects and amphibians, both native and exotic. Robertson (1991) found that 96 bird species had visited the Lake Wairarapa wetland region in the 15 years previous to his study; species included Australasian bittern (Botaurus poiciloptilus), New Zealand shoveler (Anas rhynchotis variegata), NZ dabchick (Poliocephalus rufopectus), bar-tailed godwit (Limosa lapponica), golden plover (Pluvialis fulva), pied stilt (Himantopus himantopus) and grey duck (Anas superciliosa) (Airey et al., 2000). Lake Wairarapa wetlands are well known as an area for game bird hunting; approximately $10 \%$ of the Wellington Fish and Game Councils hunters hunt there every year. Target species include invasive duck species, Canadian geese (Branta canadensis), black swans (Cygnus atratus) and paradise shelducks (Tadorna variegate) (Airey et al., 2000). Two nationally threatened fish species have been found in Lake Wairarapa: the brown mudfish (Neochanna apoda) and the giant kokopu (Galaxias argenteus), although their recent distribution and abundance is unknown (Airey et al., 2000). Pest species also inhabit the wetland; fish species such as brown trout (Salmo trutta), perch (Perca sp.) and rudd (Scardinius erythrophthalmus), as well as common mammalian pests: mustelids, feral cats, rats and rabbits. The wider lower Wairarapa area is a farming community, with ample grazing areas for primarily cattle and some sheep. No animal pest control has currently been implemented in the Wairio wetland, as little is known about potential ramifications to the current ecosystem.

\section{Restoration Project}

The current Wairio wetland restoration project is consistent with the Lake Wairarapa District Plan, Lake Wairarapa Coordinating Committee (LWCC) and DOCs Lake Wairarapa Wetlands Action Plan 2000 - 2010 and the more recent intentions of DOC, South Wairarapa District Council and Greater Wellington Regional Council (GWRC) for a regional park around the shores of Lake Wairarapa. The restoration objectives for the wetland have the full support of the diverse membership of the LWCC which includes representatives from DOC, DU, GWRC, Forest \& Bird, Fish \& Game, local Iwi (Ngāti Kahungunu) and neighbouring farmers. The project is also supported by the local community, with current involvement from Taratahi Agricultural Training Centre, Rotary members and the Pirinoa, Kahutara and Martinborough Primary Schools.

DU heads the Wairio Wetland Restoration Committee, comprising of members from LWCC as well as the Manager of Land Corp's Wairio Farm which leases the surrounding area. This Committee, which has been functioning since 2005, plans, coordinates and 
participates in work at the wetland (Ducks Unlimited, 2010). They hope this will be achieved through four mechanisms water supply and retention, re-vegetation, earth works and pest-control (Ducks Unlimited, 2010).

Three stages (5-8 ha each) within the 132-ha wetland area have been fenced off (cowproof), with restoration being initially concentrated in these areas. Within the last five years the three stages have been managed to varying degrees. Due to financial and volunteer constraints the majority of effort has been put into Stage 1 and 2 with the creation of dams, areas of seasonally open water and planting clusters of native tree species. Recently planted (in 2005, 2007 and 2009) native trees have had variable success. It was estimated that between $50 \%$ and $75 \%$ of the planted trees have survived (Silbery, 2011). The main reason for failure is assumed to be competition with Schedonorus arundinaceus (tall fescue grass). As of March 2011, Stage 3 (5.6 ha) had undergone little earth work and no replanting had taken place.

\section{Research Aims}

This thesis aims to conduct scientific research to advise the management and ecological restoration objectives of Wairio wetland, Lake Wairarapa. The two areas of focus are:

1. Determining the environmental conditions of peak abundance and limits to distribution of key native and exotic plant species in response to an environmental (hydrological) gradient and soil disturbance.

2. Investigating the interplay and cost-effectiveness of management processes that influence the establishment and survival of native woody plants typical of historic swamp forest.

This thesis has been completed in conjunction with the Wairio Wetland Restoration Committee, which holds representatives from: DU, DOC and the Greater Wellington Regional Council. It is hoped that the information gained through this research will prove invaluable to all authorities involved with wetland restoration at Lake Wairarapa and in the wider New Zealand wetland community.

\section{Thesis Structure}

There are three remaining chapters to this thesis. Chapter two explores the environmental factors that limit plant species distribution on a temporal and spatial scale. Chapter three determines the best and most cost-effective combination of treatments for successful establishment of native tree saplings. Chapters two and three have been 
arranged in part as manuscripts for journal submission and, therefore, contain some repetition and vary somewhat in style. Chapter four is a summary of the forgoing chapters and proposes recommendations for future wetland restoration projects and research opportunities at the Wairio wetland. 


\section{References}

Airey, S., Puentener, R., and Rebergen, A., 2000. Lake Wairarapa wetlands action plan, $2000-2010$. Wellington, Department of Conservation.

Ausseil, A.E., Chadderton, L.W., Gerbeaux, P., Stephens, T.R., and Leathwick, J.R., 2007. Applying systematic conservation planning principles to palustrine and inland saline wetlands of New Zealand. Freshwater Biology 56, 142-161.

Bedford, B.L., 1996. The Need to Define Hydrological Equivalence at the Landscape Scale for Freshwater Mitigation. Ecological Applications 6, 57-68.

Brock, M.A., Britton, D.L., 1995. The role of seed banks in the revegetation of Australian temporary wetlands., in: Wheeler, B.D., Shaw, S. C., Fojt, W. and Robertson, R. A. (Ed.), Restoration of Temperate Wetlands. John Wiley \& Sons, Cambridge.

Brown, S.C., Bedford, B.L., 1997. Restoration of wetland vegetation with transplanted wetland soil: An experimental study. Wetlands 17, 424-437.

Campbell, D., 2010. Hydrology, in: Peters, M., Clarkson, B. (Eds.), Wetland Restoration: A Handbook for New Zealand Freshwater Systems. Landcare, New Zealand

Campbell, D., Jackson, R.J., 2004. Hydrology of Wetlands, in: Harding, J.S., Mosley, M.P., Pearson, C.P., Sorrell, B.K. (Eds.), Freshwaters of New Zealand. Caxton press, Christchurch, pp. 2014-2021.

Casanova, M.T., Brock, M.A., 2000. How do depth, duration and frequency of flooding influence the establishment of wetland plant communities?. Plant Ecology 147, 237-250.

Clarkson, B., Peters, M., 2010. Revegetation, in: Peters, M., Clarkson, B. (Eds.), Wetland Restoration: A Handbook for New Zealand Freshwater Systems. Landcare, New Zealand

Clewall, A., Rieger, J.P., 1997. What Practitioners Need From Restoration Ecologists. Restoration Ecology 5, 350-354.

Clewell, A., Aronson, J., 2006. Motivations for the Restoration of Ecosystems. Conservation Biology 20, 420-428.

Davis, M.A., Pelsor, M., 2001. Experimental support for a resource-based mechanistic model of invisibility. Ecology Letters 4, 421-428.

Department of Conservation (DOC)., 2011. Wetlands Conservation. http://www.doc.govt.nz/conservation/land-and-freshwater/wetlands. Downloaded

December 2011.

Ducks Unlimited, 2010. Wairio wetland Restoration Project, Eastern Lake Wairarapa. www.duck.org.nz. Downloaded November 2011.

Ehrenfeld, J.G., 2000. Defining the limits of restoration: the need for realistic goals. Restoration Ecology 8, 2-9. 
Gallant, A.L., Klaver, R.W., Casper, G.S., and Lannoo, M.J., 2007. Global Rates of Habitat Loss and Implications for Amphibian Conservation. Amphibian Conservation 4, 967-979.

Gibbs, J.P., 1993. Importance of Small Wetlands for the Persistence of Local Populations of Wetland-Associated Animals Wetlands 13, 25-31.

Queensland Government., 2011. Wetland Info: Wetland Pests and Weeds. http://wetlandinfo.derm.qld.gov.au/wetlands/factsfigures/FloraAndFauna/WetlandPests.ht $\underline{\mathrm{ml}}$. Downloaded July 2011.

Greeson, P.R., Clark, J.R., and Clark, J.E., 1979. Wetland functions and values: the state of our understanding. Proceedings of a national symposium on wetlands. American Water Resources Association. Lake Lanier, Georgia.

Gren, I., Folke, C., Turner, K., and Bateman, I., 1994. Primary and Secondary Values of Wetland Ecosystems. Environmental and Resource Economics 1, 22-74.

Halle, S., Fattorini, M., 2004. Advances in Restoration Ecology: Insights from Aquatic and Terrestrial Ecosystems, in: Temperton, V.M., Hobbs, R.J., Nuttle, T., and Halle, S. (Eds.), Assembly rules and restoration ecology: bridging the gap between theory and practice.

Hansford, D., 2011. Loss, value and protection of wetlands, Department of Conservation. http://www.doc.govt.nz/conservation/land-and-freshwater/wetlands/whywetlands-are-important/loss-value-and-protection/. Downloaded July 2011.

Hobbs, R.J., Harris, J.A., 2001. Restoration ecology: repairing the earth's damaged ecosystems in the new millennium. Restoration Ecology 9, 239-246.

Jackson, L.L., Lopoukhine, N., and Hillyard, D. , 1995. Ecological Restoration: a definition and comments. Restoration Ecology 3, 71-75.

Johnson, P., Gerbeaux, P., 2004. Wetland Types in New Zealand. Department of Conservation, Wellington.

Keddy, P.A., 2006. Wetland Ecology: Principles and Conservation 2ed. Cambridge University Press, 2010.

Knight, R.L., 1997. Wildlife Habitat and Public Use Benefits of Treatment Wetlands. Water Science and Technology 35, 35-43.

Levine, C.M., Stromberg, J.C., 2001. Effects of flooding on native and exotic plant seedlings: implications for restoring south-western riparian forests by manipulating water and sediment flows. Arid Enviornments 49, 111-131.

Lewis, R.R., 2004. Ecological engineering for successful management and restoration of mangrove forests. Ecological Engineering 24, 403-418.

Mitsch, W.J., Gosselink, J.G., 1993. Wetlands. 2nd ed. John Wiley, New York.

Mitsch, W.J., Wilson, R.F., 1996. Improving the Success of Wetland Creation and Restoration with Know-How, Time, and Self-Design. Ecological Applications 6, 77-83. 
Navid, D., 1989. The International Law of Migratory Species: The Ramsar Convention. Journal of National Resources 29, 1001-1016.

Office of Energy Projects., 2004. Research of Wetland Construction and Mitigation Activities for Certificated Section 7(c) Pipeline Projects., Federal Energy Regulatory Commission: Office of Energy Projects Washington, D.C. 20426.

Palmer, M.A., Ambrose, R.F., Poff, L.N., 1997. Ecological Theory and Community Restoration Ecology. Restoration Ecology 5, 291-300.

Parks, H., Clifton, J., Best, L., Johnson, B., 2011. Now that we have our pest-proof fence, are we safe or trapped? Pacific Conservation Biology. IN PRESS.

Patten, D.T., Harpman, D.A., Voita, M.I. and Randle, T.J., 2001. A managed flood on the Colorado River: background, objectives, design, and implementation. Ecological Applications 11, 635-643.

Planty-Tabacchi. A.M., T., E., Naiman, R.J., Deferrari, C., and Decamps, H., 1996. Invasibility of Species-Rich Communities in Riparian Zones. Conservation Biology 10, 598-607.

Rea, N., Storrs, M.J., 1999. Weed invasions in wetlands of Australia's Top End: reasons and solutions. Wetland Ecology and Managment 7, 47-62.

Richardson, D.M., Holmes, P.M., Esler, K.J., Galatowitsch, S.M., Stromberg, J.C., Kirkman, S.P., Pyšek, P., and Hobbs, R.J., 2007. Riparian vegetation: degradation, alien plant invasions, and restoration prospects. Diversity and Distribution 13, 126-139.

Robertson, H.A., 1991. Lake Wairarapa wetlands management guidelines, Wellington., Department of Conservation, Wellington.

Rokosch, A., Book, J., Fennessy, S., 2001. Hydrology. www.biology.kenyon.edu/Projects/Biol493/pages/Hydrology.htm. Downloaded August 2011.

Rood, S.B., Gourley, C.R., Ammon, E.M., Heki, L.G., Klotz, J.R., Morrison, M.L., Mosley, D., Scoppetone, G.G., Swanson, S. and Wagner, P.L., 2003. Flows for floodplain forests: a successful riparian restoration. BioScience 53, 647- 656.

Schuyt, K., Brander, L., 2004. Living Waters, Conserving the Source of Life: The Economics Values of the World's Wetlands, Swiss Agency for the Environment, Forests and Landscape. Gland/Amsterdam, pp. 1-32.

Shafroth, P.B., Stromberg, J.C. and Patten, D.T., 2002. Riparian vegetation response to altered disturbance and stress regimes. Ecological Applications 12, 107123.

Sher, K., Chesson, P., 2002. Community ecology theory as a framework for biological invasions. Trends in Ecology and Evolution 17, 107-114.

Silbery, T., 2011. Personal communication with Tony Silbery: biodiversity ranger for the Deparment of Conservation, Wellington Hawke's Bay conservancy, December 2012. 
Sorrell, B.K., Gerbeaux, P., 2004. Wetland management and restoration, in: Harding, J.S., Mosley, M.P., Pearson, C.P., and Sorrell, B.K. (Eds.), Freshwaters of New Zealand, New Zealand Hydrological Society Inc., and New Zealand Limnological Society Inc., Christchurch pp. 40.41-40.12.

Stanford, J.A., Ward, J. V., and Liss, W. J., 1996. A General Protocol for the Restoration of Regulated Rivers. Regulated Rivers 12, 391-413.

The Ramsar Convention on Wetlands, 2011. The Ramsar Convention. www.ramsar.org. Downloaded November 2011.

Thompson, A.L., Luthin, C.S., 2004. Wetland Restoration Handbook for Wisconsin Landowners. 2 ed. Wisconsin Wetlands Association, Wisconsin

Tiner, R.W., 1984. Wetlands of the United States: Current and Recent Trends. U.S. Fish and Wildlife Services. Newton Comer, Massachusetts.

United States Environmental Protection Agency, U., 2000. Principles for the Ecological Restoration of Aquatic Resources, In: EPA841-F-00-003, Office of Water (4501F) United States Environmental Protection Agency Washington, DC.

United States Environmental Protection Agency, U., 2001. Threats to Wetlands In: United States Environmental Protection Agency, Washington DC.

Van Coller, A.L., Rogers, K.H., and Heritage, G.L., 2000. Riparian vegetation environment relationships: complimentarity of gradients versus patch hierarchy approaches. Vegetation Science 11, 337-350.

van der Valk, A.G., 1981. Succession in wetlands: a Gleasioian approach. Ecology 62, 688-696.

Van Diggelen, R., Grootjans, A.P. and Harris, J.A. , 2001. Ecological restoration: state of the art or state of the science?. Restoration Ecology 9, 115-118.

Vaselaar, R.T., 1997. Opening the flood gates: the 1996 Glen Canyon Dam experiment. Restoration Management Notes, 15, 119-125.

Winterhalder, K., Clewall, A., and Aronson, J., 2004. Values and Science in Ecological Restoration: A response to Davis and Slobodkin. Restoration Ecology 12, 4-7.

Zedler, J.B., Kercher, S., 2005. Wetland Resources: Status, Trends, Ecosystem Services, and Restorability. Annual Review of Environment and Resources 30, 39-74. 


\section{SPATIAL AND TEMPORAL PATTERNS OF PLANT COMMUNITIES DURING SUMMER DESICCATION AT A SEASONAL WETLANDS, SOUTHERN WAIRARAPA}

\section{Introduction}

Zonation is commonly seen in plant communities subject to gradients in physical stress (Whittaker, 1967; Barbour, 1980). The most important environmental (external) factors for plants in wetland habitats include water levels, oxygen and temperature range (Johnson and Rogers, 2003). Most ephemeral wetland plants display a strong pattern of zonation, through a succession from open water to dry land which is correlated in some way with duration and periodicity of water inundation. Zones of turf and sward communities often grade downslope to aquatic plant and may merge upslope to rushland and sometimes scrub or forest (Johnson and Rogers, 2003). This hydrosere reflects differences in the degree of adaptation to aquatic life of different plant species. The decline of wetland abundance and health since European settlement, due to stabilisation of the water table, has created wetlands that are more continuously wet or dry. This has a significant effect on species composition and biomass of establishing plants (Seabloom et al., 2003b). Another factor adversely affecting diversity in wetlands is the spread of dominant weed species from the seed banks (Leck, 1989). Exotic species present in the seed bank may propagate during favourable conditions, then, once established, competitively exclude native plant species (van der Valk and Penderson, 1989).

Hydrological changes are a major determinant in development of plant communities and the patterns of zonation in wetlands. Ephemeral wetlands experience natural water level fluctuations that results in cyclic vegetation changes, with the plants arranging 
themselves across gradients according to their ability to tolerate flooding (Odland and del Moral, 2002b). These patterns are described by the depth, duration, frequency, rate of filling and drying, timing and predictability of flooded and dry phases in a wetland (Bunn, 1997). Plants appear at different times after water recedes (Odland and del Moral, 2002a), making it difficult to predict the composition of the plant communities. The succession of floristic change includes two major processes occurring simultaneously temporal species turnover and spatial separation in relation to water level (Odland and del Moral, 2002a). Understanding how the water regime affects plant communities, especially with rare natives present, can assist in managing wetlands more predicatively (Brock and Britton, 1995) and, therefore, more efficiently in relation to desired management and conservation outcomes.

Historically, zonation of plant species was believed to result from variation in physical parameters along gradients of depth and exposure (Whittaker, 1956; Hutchinson, 1975). More recent studies have extended this to the importance of biotic interactions, particularly competition, in mediating plant zonation (Grace and Wetzel, 1981; Silander and Antonovics, 1982; Gurevitch, 1986). There is growing evidence that competition controls the distributional limits of vascular plant species found along environmental gradients such as soil moisture (Gurevitch, 1986), soil pH (Grime, 1963), water depth (Grace and Wetzel, 1981), soil depth (Sharitz and McCorkmick, 1973), soil fertility (Goldberg, 1982) and salinity (Snow and Vince, 1984). Plant community composition and zonation is the result of establishment of individual plants in their preferred environment in the short term, with competitive interactions becoming more important in the established phase of community development (Casanova and Brock, 2000).

Typically, in New Zealand, the plants of ephemeral wetlands have the stature of turf (Johnson and Rogers, 2003). At Lake Wairarapa, the lake edge supports a turf community of native plants, the largest by area compared with other New Zealand North Island lakes (Johnson and Rogers, 2003). There are a number of rare or threatened plants inhabiting the Lake Wairarapa area, including the turf species Leptinella maniototo, Crassula ruamahanga, Lobelia carens, Pilularia novaezelandiae, Glossostigma elatinoides, Hypsela rivalis and Amphibromus fluitans (GWRC, 2003) (Common names in Appendix 2.1). The Wairio Wetland is surrounded by pasture grasslands, scrublands, exotic willow trees and even remnant native forest, which comprises Dacrycarpus dacrydioides, Cordyline australis, Podocarpus totara and Sophora microphylla trees. Small in size, New Zealand's native wetland turf plant 
species are often outcompeted by more aggressive weeds, such as Glyceria maxima, Alisma spp., Isolepis prolifera and other common pasture grasses. These invade during the desiccation period, when wetland plants are most vulnerable and the surrounding vegetation invades (Champion, 1998). To conserve these vulnerable native plants a better understanding of their spatial and temporal dynamics and optimal environmental conditions is required, as well as an understanding of their response to artificial disturbances designed to reduce competition.

Two studies are reported here. The initial study focuses on the creation of suitable conditions for rare native turf and management techniques that minimise the competitive impacts of introduced plants at Stage one (Figure 2) of the Wairio wetland. Removal of topsoil has been proposed as a management technique in wetland restoration as a way of resetting succession away from pasture grasses toward a more natural community and as a form of site preparation ahead of tree-planting (see Chapter three) (Ramseier, 2000). The objective of this study was to investigate the temporal and spatial dynamics of exotic species that are thought to compete with turf native species after desiccation at an ephemeral wetland. The aim was to determine the environmental conditions of peak abundance and limits to distribution of key native and exotic plant species along an environmental (hydrological) gradient. A second study was conducted to further investigate the effect of topsoil removal on the plant community. This stands as a comparison with the initial study at Stage one, which is a detailed study of a 50-m spatial gradient, incorporating a temporal component. The second is a snap-shot observation over a wider extent and a wider range of hydrological conditions.

\section{Methodology}

\section{Study Area}

This study was completed over two summers (2010/2011 and 2011/2012) and was conducted as a sampling survey at the Wairio wetland, Lake Wairarapa. The Wairio wetland block is on the eastern shores of Lake Wairarapa and is co-managed by Department of Conservation (hereafter regarded as DOC) and Ducks Unlimited New Zealand (hereafter referred to as DU). Wairio wetlands have been negatively affected by human development since the 1960s. The goals of the Lower Wairarapa Development Scheme saw Lake Wairarapa being partially drained, the shore regions being cleared of forest and sedges and willow trees planted for erosion control - resulting in an infestation in the wetlands and the construction of Parera Road which separated Wairio from the 
adjacent Boggy Pond wetland (Figure 2). Serious restoration efforts began in 2005, with DU taking the lead. Three fenced areas (5-8 hectares) within the wetland are the sites for restoration work thus far. Stage one is where the initial experiment took place for this study and Stage three is where the 2012 experiment occurred (Figure 2).

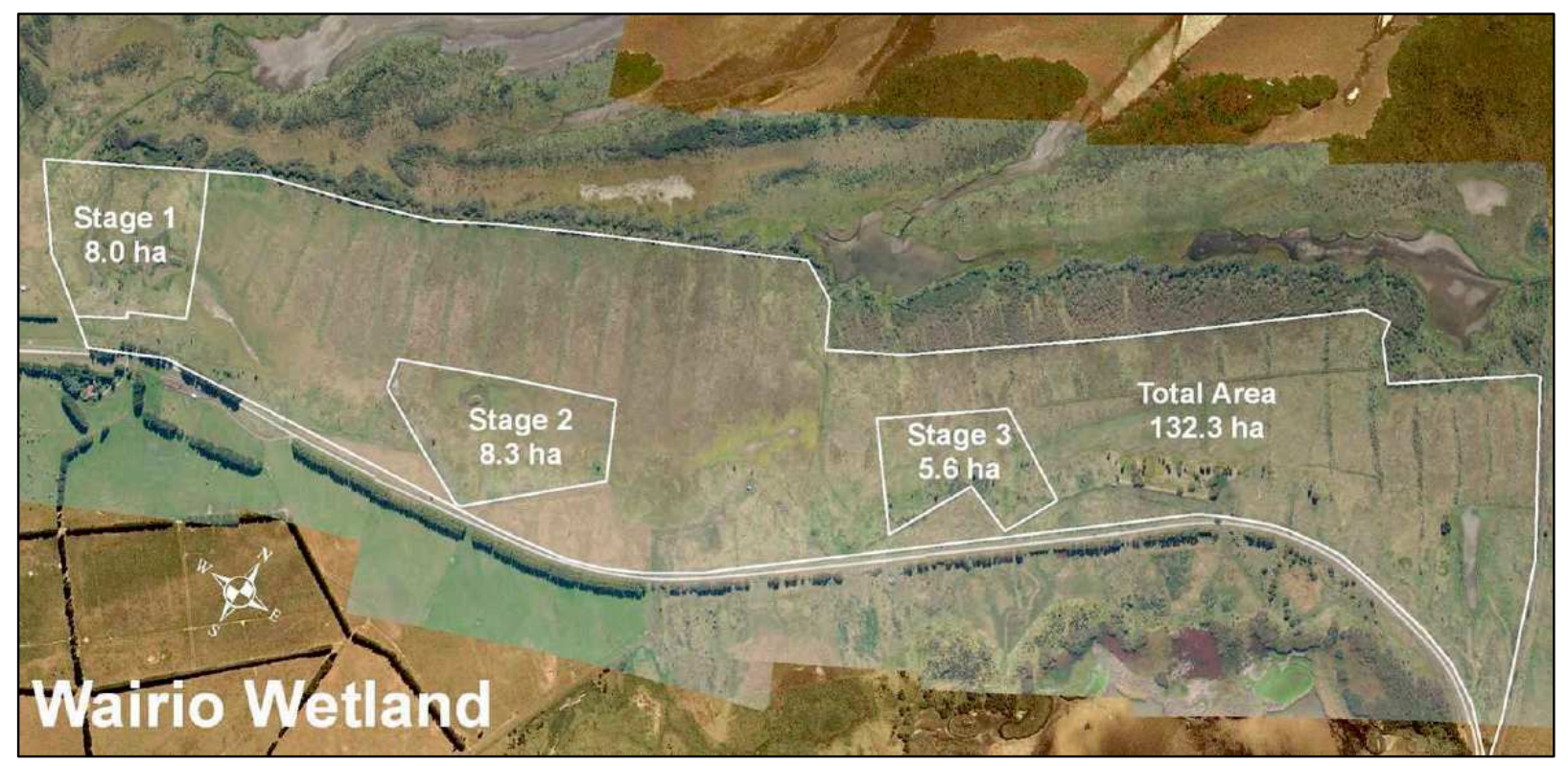

Figure 2 Aerial photo of Wairio wetland, showing Stage 1, 2, and 3 (Greater Wellington Regional Council, 2010).

\section{Fine-scale Temporal and Spatial Plant Dynamics along a Hydrological}

\section{Gradient}

\section{Experimental Layout and Data Collection}

At Stage one, during the desiccation period in April 2010, surface vegetation was mechanically removed in two perpendicular scrapes to remove the seed bank of invasive pasture grasses. The scrapes lowered soil surface level relative to the surroundings thereby increasing overall soil moisture. In December 2010, 20 1-m square quadrats were set 5-m apart along two 50-m transects within the scrapes (Figure 3, Appendix 2.2). The two transects were initially established by DOC staff in early 2010. The first transect followed the moisture gradient running into the artificial pond, whilst the second ran perpendicular to the first (acting as control plots). Poles were secured in each corner of the quadrats allowing them to be repeatedly located. The site was visited approximately every two weeks for 14 weeks (Appendix 2.3). At each visit, plant composition was identified in each quadrat and the dominant species were quantified. Specimens of any 
unknown species were collected, labelled and brought back to the lab for identification. The following abiotic variables were measured soil moisture, soil $\mathrm{pH}$, percentage open ground and percentage water, water depth, daily sunshine hours and daily rainfall. Dominant species were quantified by estimating the percentage ground cover of each species, rounded to the nearest ten percentage. Soil moisture and $\mathrm{pH}$ were measured using a three-in-one probe (McGregor's, 3XMETER), which was placed at the same location inside the quadrat at each visit. This provided measurements of soil moisture on an arbitrary scale using relative units from 1 to 10 . The measurements of percentage water cover, open ground and plant cover were subjective visual estimates made by the author. Water depth was measured with a ruler. Weather conditions representative for the site as a whole were determined as an average of the 13-16 days preceding each visit (the precise interval being determined by the time since the previous visit). Sunshine hours and rainfall were calculated from records held by Gladstone weather station (WMAC, 2011). Weather conditions from the first visit were averaged from the two weeks previous. 


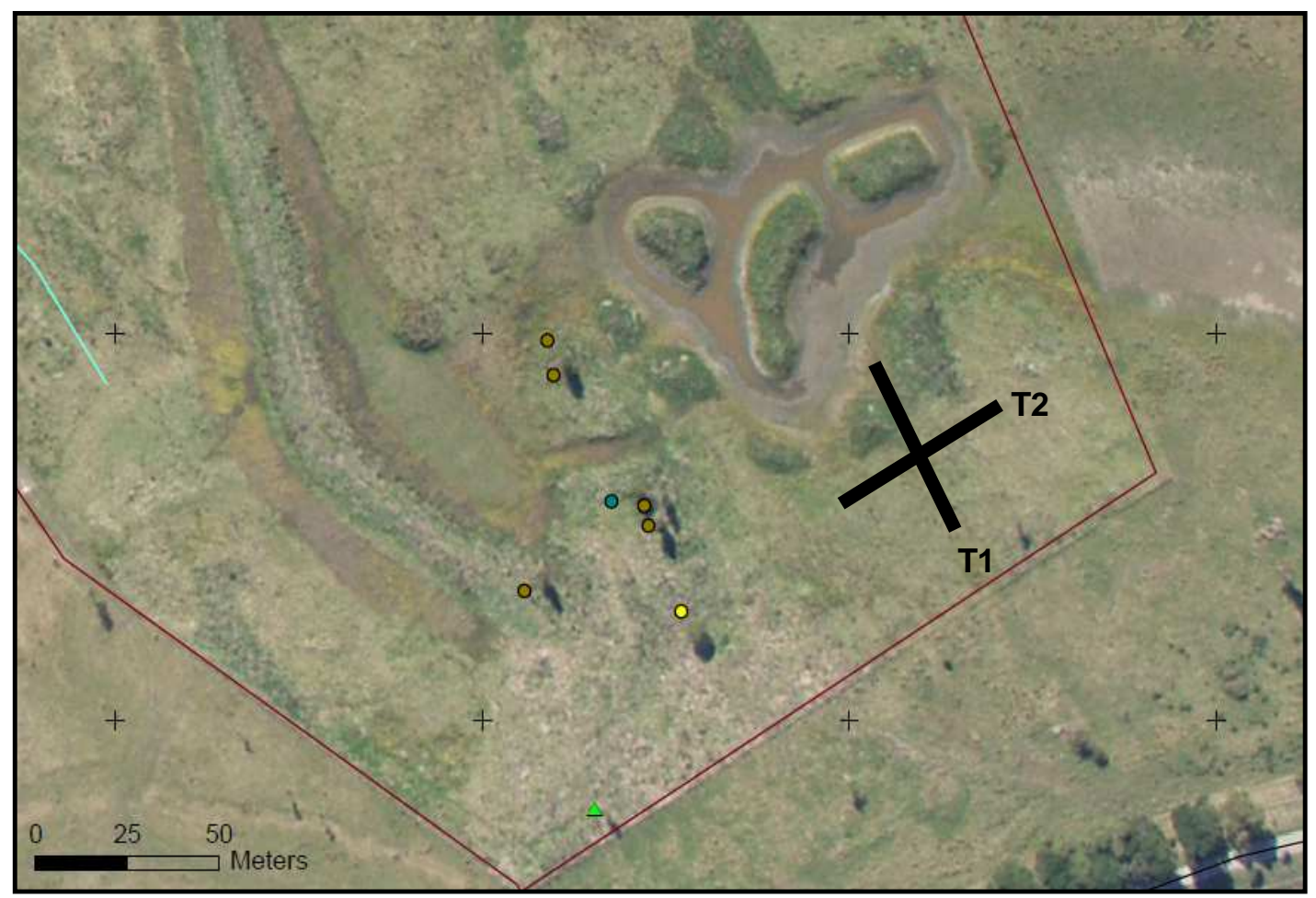

Figure 3 Stage 1 (red fence outline) with two perpendicular 50-m transects (black lines), each has 10 quadrats across them, $5 \mathrm{~m}$ apart. T1 = Transect 1, T2 = Transect 2.

\section{Data Analysis}

The mean, minimum and maximum values of the environmental variable (soil moisture and $\mathrm{pH}$ ) were calculated for each quadrat. Percentage cover of five species (Alisma spp., G. maxima, I. prolifera, G. elatinoides and L. perpusilla and common pasture grasses) was calculated for each month; an average of two measurements in January, February and March. Glossostigma elatinoides and Lobelia perpusilla were combined due to their native status, identical conditions and identical abundance.

Environmental niche models: Relationships between abundance (percentage cover) and each environmental variable were explored using logistic models. The response variable (percentage cover) was modelled as the outcome of 10 Bernoulli trials (presence/absence in one-tenth of a quadrat) whose summation corresponds to cover values of $0,10,20 \ldots 90,100 \%$ ). For each environmental variable, three alternative models of increasing complexity were compared: (i) a simple intercept-only model in which the environmental variable has no influence on abundance, (ii) a logistic curve model in which abundance is modelled to vary from 0 to $100 \%$ or vice versa along an environmental gradient and (iii) in which the species displays a unimodal optimum at an 
intermediate value of the environmental gradient (modelled as a normal curve). A logistical sigmoidal curve is equivalent to a linear trend on a logit scale and the unimodal opimum is a quadratic curve on the logit scale, but a normal curve on the original scale. The relative support for each model, given the data at hand, was assessed using the Akaike Information Criterion (AIC) with a correction for sample sizes (AICC) (Burnham and Anderson, 2002). The model with the lowest AIC is considered to be the one with the best support from the data. The difference between the best model with the lowest AIC and alternative models is measured by the change in AIC ( $\triangle A I C)$. Alternative models with $\triangle$ AIC less than two are plausible alternatives (Burnham and Anderson, 2002).

\section{Association between Plant Communities and Soil Moisture}

\section{Study Area and Methods}

During 2010 , ten $40 \mathrm{~m}$ by $30 \mathrm{~m}$ blocks were created in Stage three of the Wairio wetland (Figure 4) and were sites of a large-scale manipulative field experiment, which involved the planting of $\sim 2,400$ native trees (detailed in Chapter three of this thesis). Across half of each block (i.e. $20 \mathrm{~m} \times 30 \mathrm{~m}$ half-blocks) the topsoil was mechanically scraped away using a bulldozer on April $29^{\text {th }} 2011$, prior to tree planting (see Chapter 3 for details). This treatment was intended to remove aggressive alien grasses. This study will focus on the effect of topsoil removal by mechanical scraping on the background vegetation community. In addition, the effect of soil moisture was incorporated as a covariate with a potentially important influence in structuring wetland communities. On $29^{\text {th }}$ April 2011, six inches of topsoil off each half-block were excavated. On the remaining half-blocks, $1-\mathrm{m}^{2}$ marks were sprayed with a herbicide cocktail (Buster, glufosinate-ammonium and Gardoprim, tebuthylazine) on May $31^{\text {st }} 2011$ around where each native sapling was planted in late June 2011 (120 natives per half-block).

Data collection for this study took place between the $22^{\text {nd }}$ and $24^{\text {th }}$ January 2012 (nine months after the mechanical scraping). Five 1-m by 1-m quadrats were randomly placed in each half-block, with a minimum distance of 5-m between each quadrat and GPS coordinates taken (Appendix 2.4). A total of 68 quadrats were measured; 35 in topsoil removed half-blocks, 33 in topsoil remaining half-blocks. Plant composition was identified in each quadrat (as percentage cover of each species present), as well as the maximum height of the total vegetation. Specimens of any unknown species were collected, labelled and brought back to the lab for identification. 
The following abiotic variables were measured soil moisture; percent open ground, percent ground water and water depth. Species present were quantified by estimating the percent ground cover of each species, rounded to the nearest five percent. Soil moisture was measured using a soil probe (McGregor's, 3XMETER), which gave measurements on an arbitrary scale using relative units from 1 to 10 . The probe was placed on the north-eastern corner of each quadrat. The measurements of percentage water cover, open ground and plant cover were subjective estimates made by the author. Water depth was measured with a ruler.

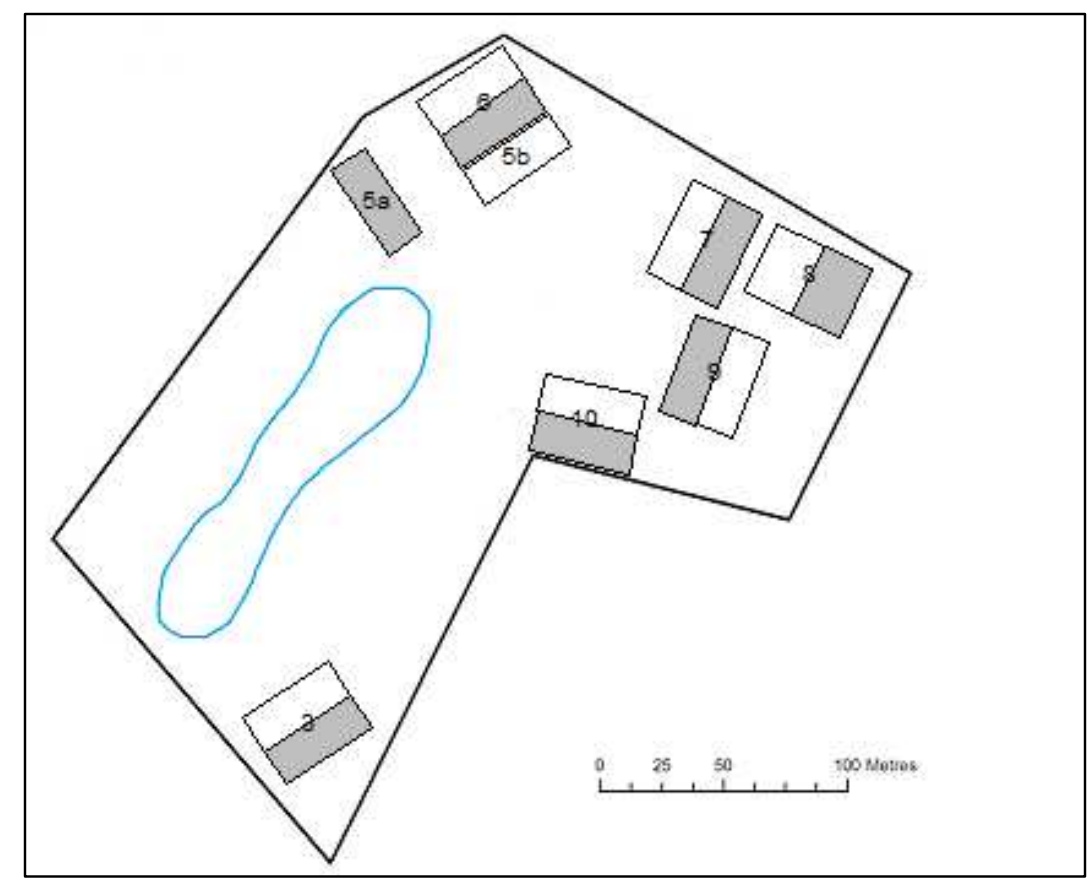

Figure 4 Adjusted map of Stage 3, Wairio wetland, showing seven blocks of experimenting. Block halves shaded grey have had the topsoil removed (scraped); the white halves have the topsoil remaining (unscraped).

\section{Data Analysis}

Community ordination methods were used for initial exploratory analysis. Principle coordinate analysis (PCoA, also called metric multidimensional scaling) was used to visualise the total variation of the plant community across the entire set of quadrats. Univariate responses of key species were then examined with simple Pearson correlation tests and with generalised least square (GLS) models, also known as spatial regression models. The GLS method is similar to ordinary general linear models, but it controls for potential spatial autocorrelation in the residuals which can lead to inflated 
type 1 errors if it is ignored (Dormann, 2007). For the GLS analyses the response variable was percentage cover (modelled as a continuous and unbounded variable) and the predictors were soil moisture, soil moisture squared (to allow for non-linear responses) and the scraping treatment (with two levels); spatial autocorrelation in the observations was accounted for by the automated and iterative fitting of a spherical semi-variogram to the residuals. All analyses were conducted in the statistical package $R$ 2.14. The package 'labdvs' was used for ordination and 'nlme' for GLS. Any rare species that were present in three or less quadrats were removed from the dataset, leaving 20 species in the ordination (Appendix 2.5).

\section{Results}

\section{Fine-scale Temporal and Spatial Plant Dynamics along a Hydrological Gradient}

\section{Description of the Abiotic Environment}

Transect one (T1) was the focus of the results, as it ran directly towards the permanent water reflecting the major soil moisture gradient. Transect two (T2) provided additional data in the mid-range environmental conditions. The ground elevation profile along T1 corresponds positively with average soil moisture (Figure 5A). As the elevation increases $(0.3762 / \mathrm{m})$, soil moisture gradually increases $(0.0536 / \mathrm{m})$. The highest elevation peaks is at 50-m (16 cm), which includes Q10. The main depressions are at 30-m (-6 cm), 36-m ($4 \mathrm{~cm})$ and $48-\mathrm{m}(-3 \mathrm{~cm})$, which incorporate $\mathrm{Q} 6, \mathrm{Q7}$ and some of $\mathrm{Q} 9$, respectively. 

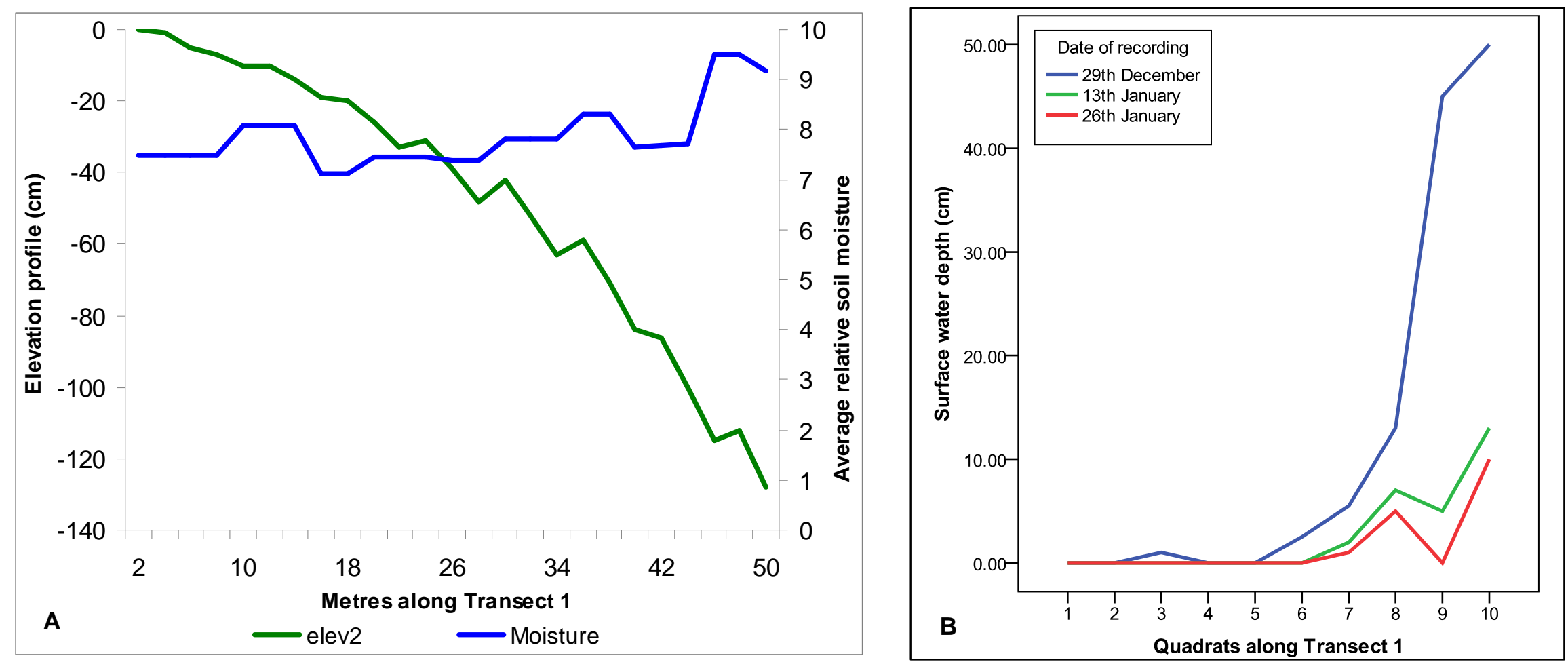

Figure 5 A) Elevation profile and average soil moisture along Transect 1. Slope is measured in 2-m increments. B) Surface water depth (cm) along Transect 1 in 2010/2011. No surface water was present along this Transect at subsequent visits 4-7. The quadrats in 5B relate to every $2 \mathrm{~m}$ along $5 \mathrm{~A}$. 
The wetland site was visited and recordings made seven times over the summer period (Figure 6, Appendix 2.6). During the first three visits to the Wairio wetland, surface water was observed within some of the quadrats of transect 1 (Figure 5B). The greatest quantity of water was present at the first visit, with six quadrats consisting of surface water (Q3, Q6-10). By visit two and three, only four plots had surface water (Q7-10); however, the latter date had shallower water across the quadrats. Early January saw the highest daily sunshine hours recorded; with the sunniest period extending until the $23^{\text {rd }}$ February. Preceding visit seven was the period of least sunshine hours, with a daily average of 4.69 hours. Recordings prior to visit three had the greatest rainfall, with an average of $7.07 \mathrm{~mm} /$ day. From February to mid-March there was virtually no rainfall; a total of $4.7 \mathrm{~mm}$ was recorded between the third and fourth visit.

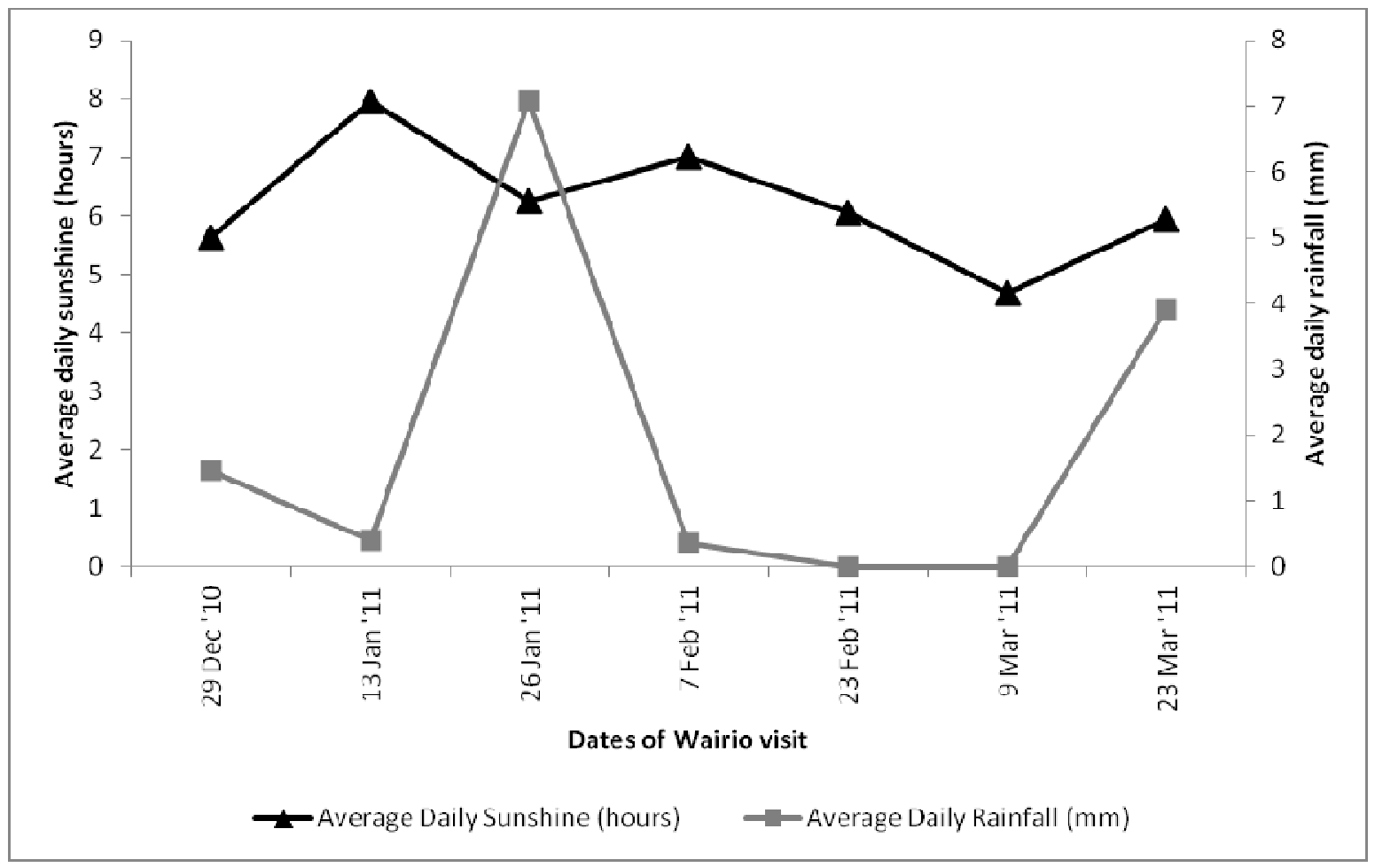

Figure 6 The average daily rainfall and sunshine hours over the experiment time (averaged from the $\sim 2$ weeks preceding $\sim 2$ weeks each visit). 
Soil moisture was the key environmental factor influencing plant distribution along T1 (and T2). The soil moisture readings for T1 were as expected moisture in the soil increased with proximity to the pond (Figure 7). Over the four months soil moisture ranged from an average of 7.00 at $\mathrm{Q} 2$ to 9.51 at $\mathrm{Q} 9$.

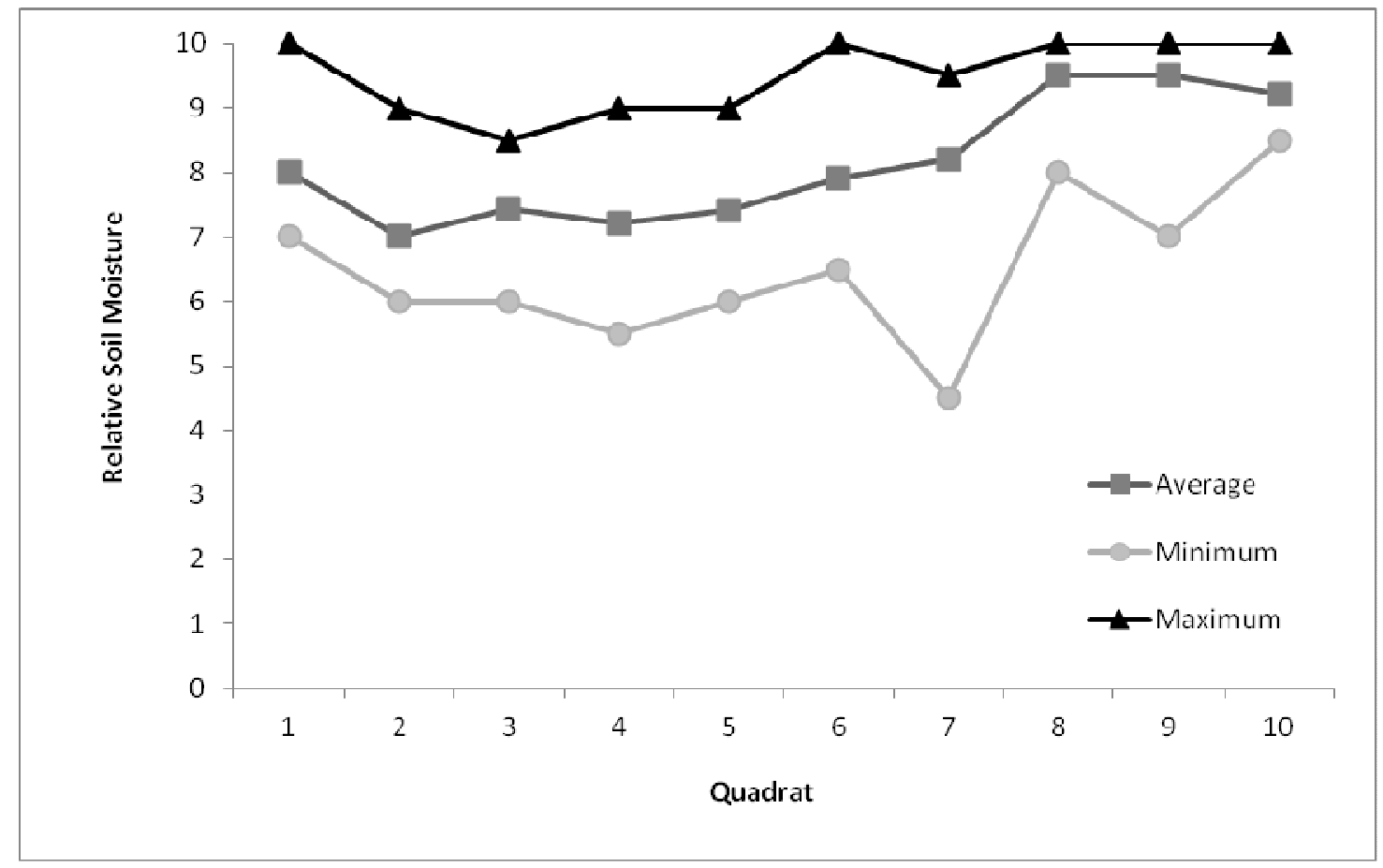

Figure 7 Soil moisture gradient showing maximum, minimum and average recordings along Transect $\mathbf{1}$, Quadrats 1-10, n=7 visits from Dec 2010 to March 2011. 
Soil $\mathrm{pH}$ showed little variance along $\mathrm{T} 1$ ranging from between 6.5 to 8 , with an average of 7.60 (Figure 8). This is comparable with T2 which has an identical range and average of 7.69 Figure 9).

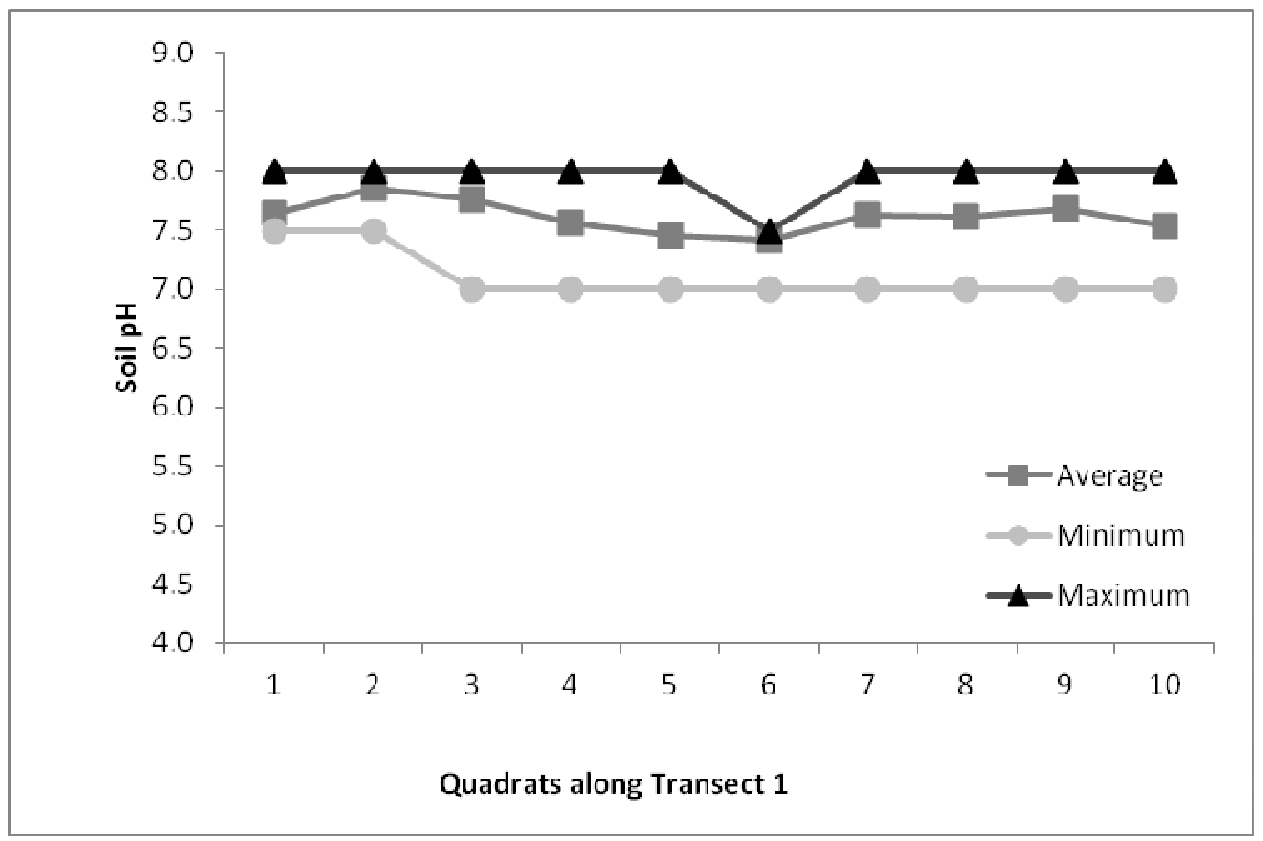

Figure 8 Soil pH gradient showing maximum, minimum and average recordings along Transect 1, Quadrats 1-10.

T2 shows minor variation in soil moisture and soil $\mathrm{pH}$ levels ( Figure 9). Apart from the initial low soil moisture at Q1, soil moisture is fairly constant, with a range from 6.34 to 7.84 . 


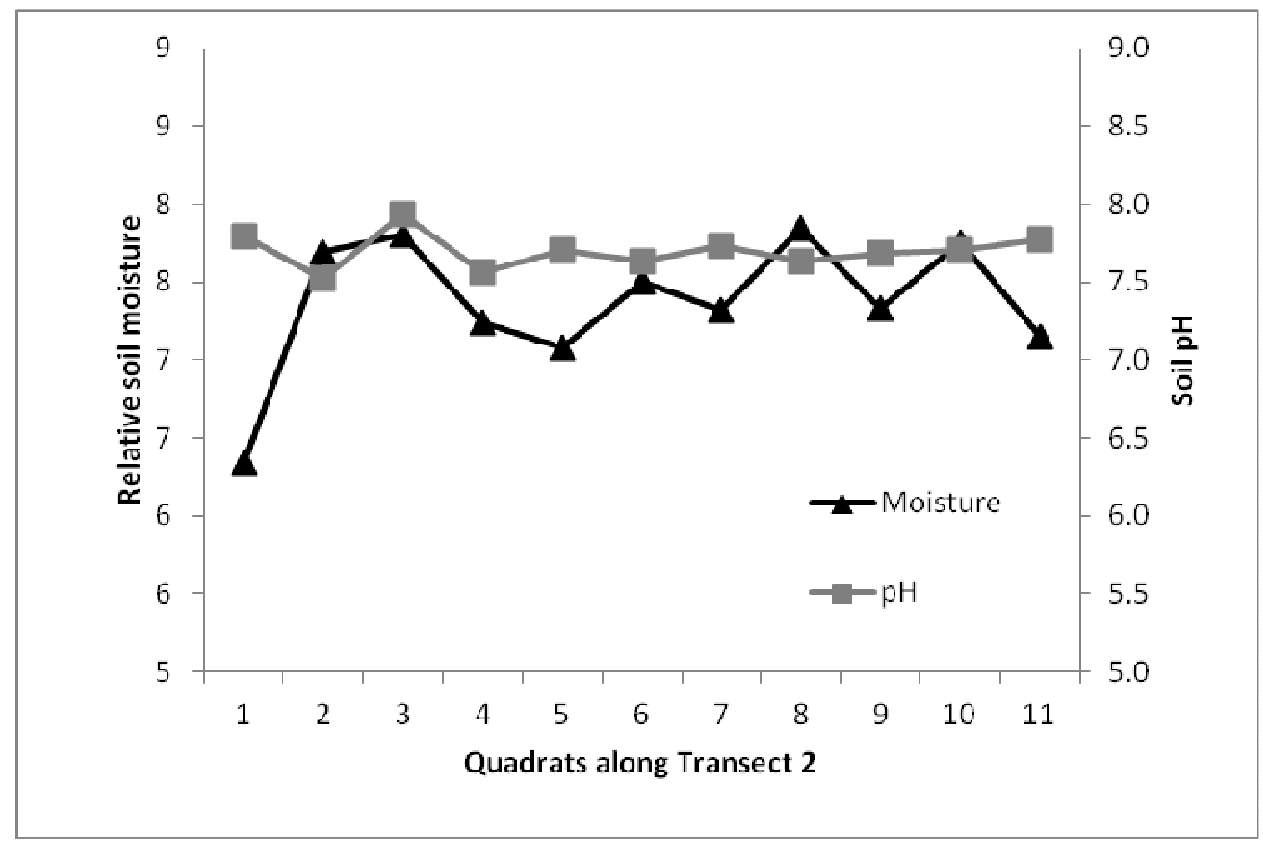

Figure 9 Average soil moisture and pH recordings along Transect 2, Quadrats 1-11. 
The third key environmental factor measured was percentage open ground. Figure 10, shows the minimum, average and maximum open ground, across T1. There are peaks in percentage open ground at Q2, Q6 and Q10. The highest densities of plants are at Q5 and Q9.

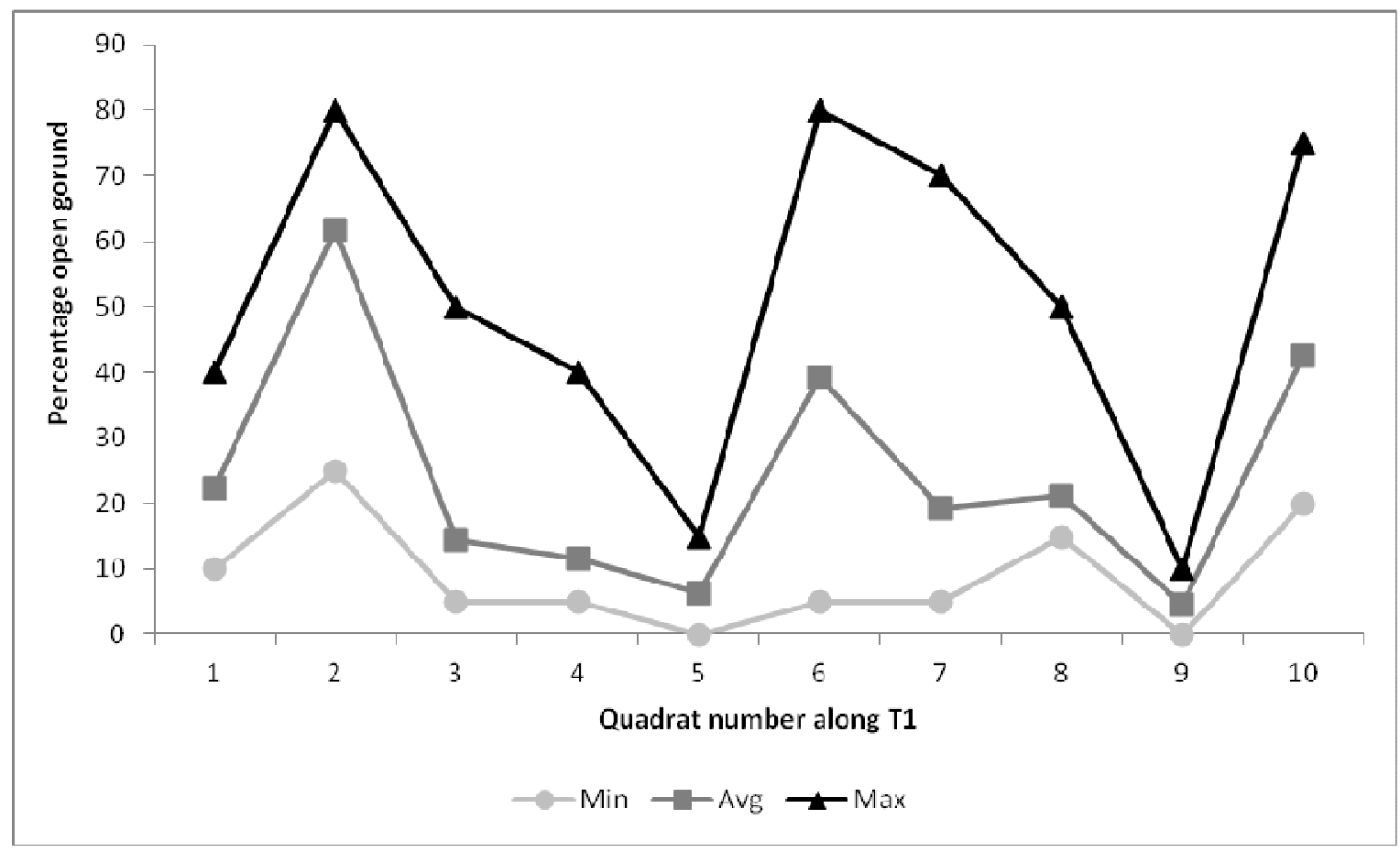

Figure 10 Maximum, average and minimum percentage of open ground in each quadrat along Transect 1, Quadrats 1-10.

Table 4 shows Spearman's correlations comparing the three key environmental factors; soil moisture, soil pH and percentage open ground. There are no significant correlations; soil moisture and soil pH show a weak negative correlation, soil moisture and percentage ground cover show a weak positive correlation and percentage open ground and soil $\mathrm{pH}$ showed no correlation.

Table 4 Spearman's correlations, between 3 key environmental factors soil moisture, soil pH and percentage open ground ( $n=20, p$-values in parentheses, * indicates significant results).

\begin{tabular}{lll}
\hline $\begin{array}{l}\text { Environmental } \\
\text { factors }\end{array}$ & Soil pH & $\begin{array}{l}\text { Percentage open } \\
\text { ground }\end{array}$
\end{tabular}

$\begin{array}{lll}\text { Soil Moisture } & -0.141(0.55) & 0.158(0.51) \\ \text { Soil pH } & & 0.068(0.78)\end{array}$


Spatio-Temporal Patterns in the Plant Community

Throughout the desiccation period, the dominant plant species were all introduced species (G. maxima, Alisma spp., Lythrum hyssopifolia, Gallium propinquum and common pasture grasses (Appendix 2.7)). Across the hydrological gradient of T1, Alisma spp. dominated the high soil moisture sites (Q6-Q10), while G. maxima dominated the relatively lower soil moisture (Q1-Q6) (Figure 11). The dominant species within the quadrat varied depending upon the timing of the visit through the season. 


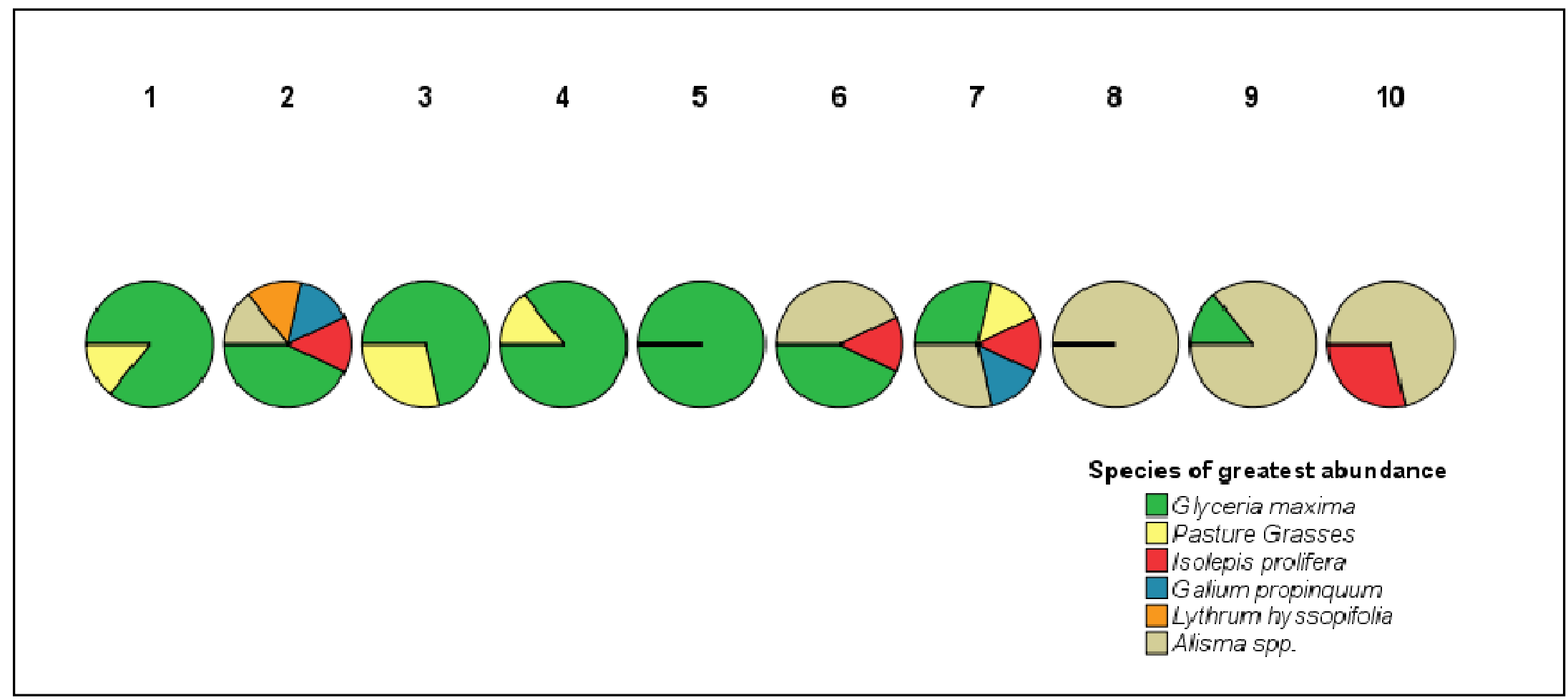

Figure 11 Species of greatest abundance in each quadrat in Transect 1, Quadrats $1-10$. Results shown over all visits, i.e. each slice represents individual visits. 
The spatio-temporal dynamics of five key species are illustrated further in Figure 12 Isolepis prolifera grows rather consistently through a range of soil moistures, but never in standing water. Native turf species Glossostigma elatinoides and Lobelia perpusilla grow in soil with high moisture content (min. soil moisture 9). Alisma spp. grows more abundantly in highly moist soil but occupies a greater range of soil moisture than the native species (min. soil moisture 7). Glyceria maxima grow more abundantly in low moisture soil and also occupy a greater variance of soil moisture (min. soil moisture 5.5). The native species emerge later in the summer season, whereas Alisma spp. are a consistent component of the high soil moisture quadrats during the desiccation period. Glyceria maxima increase slightly in abundance over the summer, whereas Alisma appeared to decline in abundance (Figure 12). No A. fluitans was recorded in any of the quadrats although it is sporadically present in Stage one around the margins of the retreating pond water (Silbery, personal comms.). 


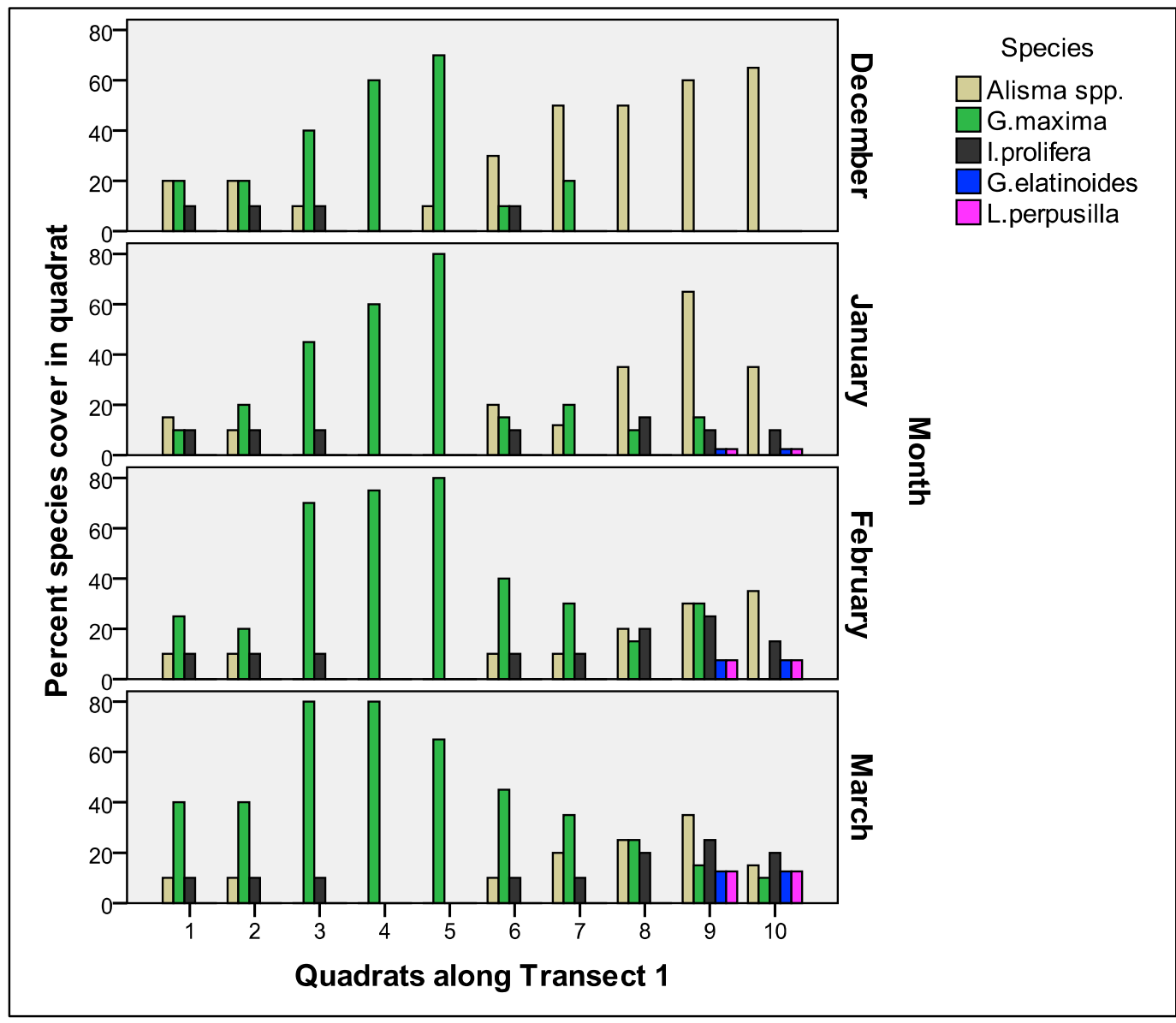

Figure 12 Percentage cover of the three most abundant introduced species and the two rare native turf species, in each quadrat, shown over the four months of observation. January, February and March data are the average of two visits. There was only one visit during December. Quadrats generally show a positive soil moisture gradient (highest average soil moisture at quadrat 10 , see Figure $5 \mathrm{~A}$ )

\section{Environmental Niche Models}

For four out of the five taxa (Alisma spp., G. maxima, G. elatinoides, L. perpusilla and the common pasture grasses), the relationship between abundance and the environment was best described by a humpbacked relationship (Model 3) in relation to average soil moisture (Table 5 and Figure 13A to D). The optimum average soil moisture for each species was 9.25 for G. elatinoides and L. perpusilla, 8.9 for Alisma spp., 7.6 for G. maxima and 7.5 for the common pasture grasses. Isolepis prolifera is best described by a negative relationship with soil moisture (Model 2) across the range of values sampled (Table 5 and Figure $13 \mathrm{E}$ ). 
Table 5 Comparison of environmental niche models for the six most common plant taxa at Wairio wetland

\begin{tabular}{|c|c|c|c|c|c|c|c|c|c|c|c|}
\hline & \multirow[b]{2}{*}{ Model $^{1}$} & \multicolumn{2}{|c|}{ Alisma spp. } & \multicolumn{2}{|c|}{ I. prolifera } & \multicolumn{2}{|c|}{ G. maxima } & \multicolumn{2}{|c|}{ Common Pasture Grasses } & \multicolumn{2}{|c|}{$\begin{array}{c}\text { G. elatinoides and } \\
\text { L. perpusilla }\end{array}$} \\
\hline & & $\Delta \mathrm{AIC}_{\mathrm{c}}{ }^{2}$ & Description $^{3}$ & $\Delta \mathbf{A I C} \mathbf{c}_{\mathrm{c}}$ & Description & $\Delta \mathbf{A I C}_{\mathrm{c}}$ & Description & $\Delta \mathrm{AIC}_{\mathrm{c}}$ & Description & $\Delta \mathbf{A I C} \mathbf{c}_{\mathrm{c}}$ & Description \\
\hline AvgSoilMoist & 1 & 5.77 & & 2.66 & & 23.89 & & 6.48 & & 5.32 & \\
\hline AvgSoilMoist & 2 & 1.08 & +ve & 4.59 & $+v e$ & 7.88 & & 1.42 & -ve & 4.38 & \\
\hline AvgSoilMoist & 3 & 0 & $7.7-10$ & 3.8 & 7.5-9.5 & 0 & $6.7-8.5$ & 0 & $6.6-8.4$ & 0 & $9.0-9.5$ \\
\hline AvgSoilpH & 1 & 5.77 & & 2.66 & & 23.89 & & 6.48 & & 55 & \\
\hline AvgSoilpH & 2 & 7.97 & & 2.4 & $+v e$ & 25.69 & & 8.68 & & 56.82 & \\
\hline AvgSoilpH & 3 & 10.16 & & 2.31 & $7.6-7.9$ & 28.16 & & 10.81 & & 58.96 & \\
\hline MinSoilMoist & 1 & 5.77 & & 2.66 & & 23.89 & & 6.48 & & 5.32 & \\
\hline MinSoilMoist & 2 & 5.08 & $+v e$ & 0 & -ve & 19.82 & & 7.01 & -ve & 5.17 & $+v e$ \\
\hline MinSoilMoist & 3 & 6.56 & $2.0-7.0$ & 0.95 & $5.0-9.0$ & 14.02 & $3.8-6.8$ & 6.02 & $4.0-6.8$ & 5 & $7.0-8.0$ \\
\hline
\end{tabular}

${ }^{1}$ Model specifications: model 1 = intercept-only, model 2 = linear trend (sigmoidal), model $3=$ humpbacked relationship (with 1,2 and 3 estimated parameters respectively)

${ }^{2} \Delta \mathrm{AICC}$ is the AIC value of each model relative to the best model (i.e. the best- supported model of the nine candidate models has a value of zero). Models within 2 AIC points of the best model are also worthy of consideration and are in bold type.

${ }^{3}$ Description of model for model 2 the description is the direction of the linear trend and model $3=$ range of environmental values predicted to have above-average vegetation cover of the species. Descriptions are provided where models are within 2 AICc points of the best model for a particular environmental factor. Model 1 is a null model and requires no description. 
Bridget A. Johnson
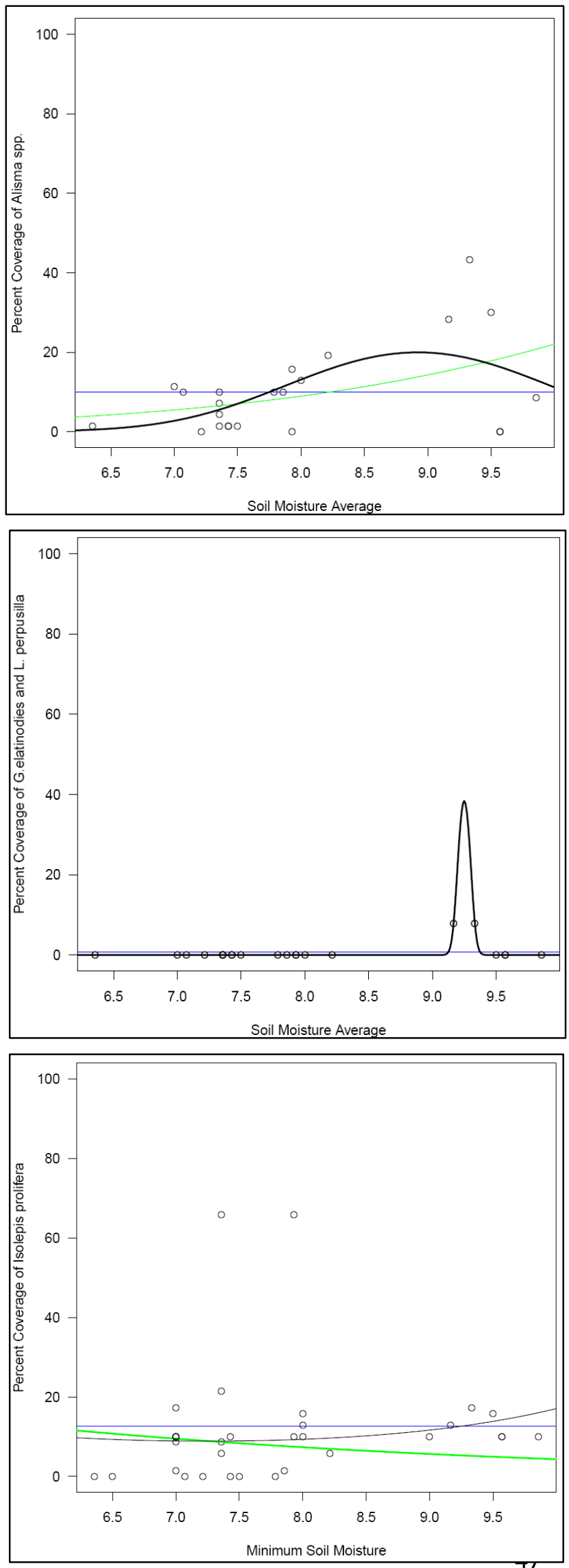

Wairio Wetland Restoration 2012
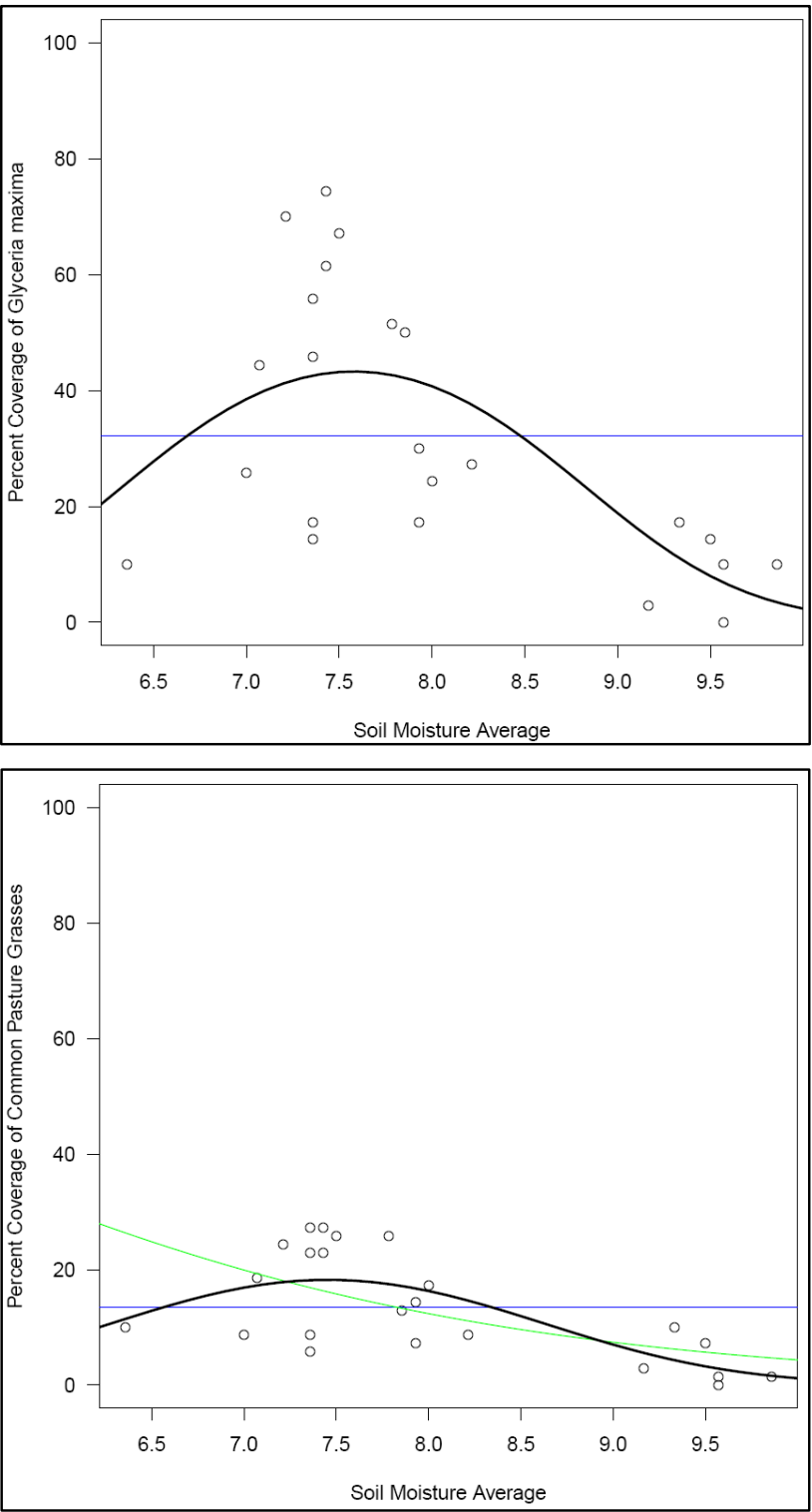

Figure 13 Graphs of potential best fit niche models describing the percent cover of each species A) Alisma spp. against soil moisture average B) G. maxima against soil moisture average C) G. elatinoides and L. perpusilla against soil moisture average D) Common Pasture Grasses against soil moisture average E) / prolifera against minimum soil moisture. Model 1 = intercept-only at average value (blue), model 2 = linear trend (green), and model 3 = humpbacked relationship (black). The best supported model (lowest AIC) has been bolded in each graph. 


\section{Association between Plant Communities and Soil Moisture}

The focus of this study was to determine how scraping of topsoil affects the plant community by comparing scraped and unscraped areas experimentally replicated across Stage three, while also considering the influence of soil moisture. Twenty-three species were recorded, the most common being Holcus lanatus, Agrostis capillaris, Juncus articulates and Trifolium pratense. Only twenty species present in three or more quadrats were used in the PCoA. In the PCoA on plant communities the first three principle coordinates explained $56.33 \%$ (2dp) of the variance (Figure 14$)$.

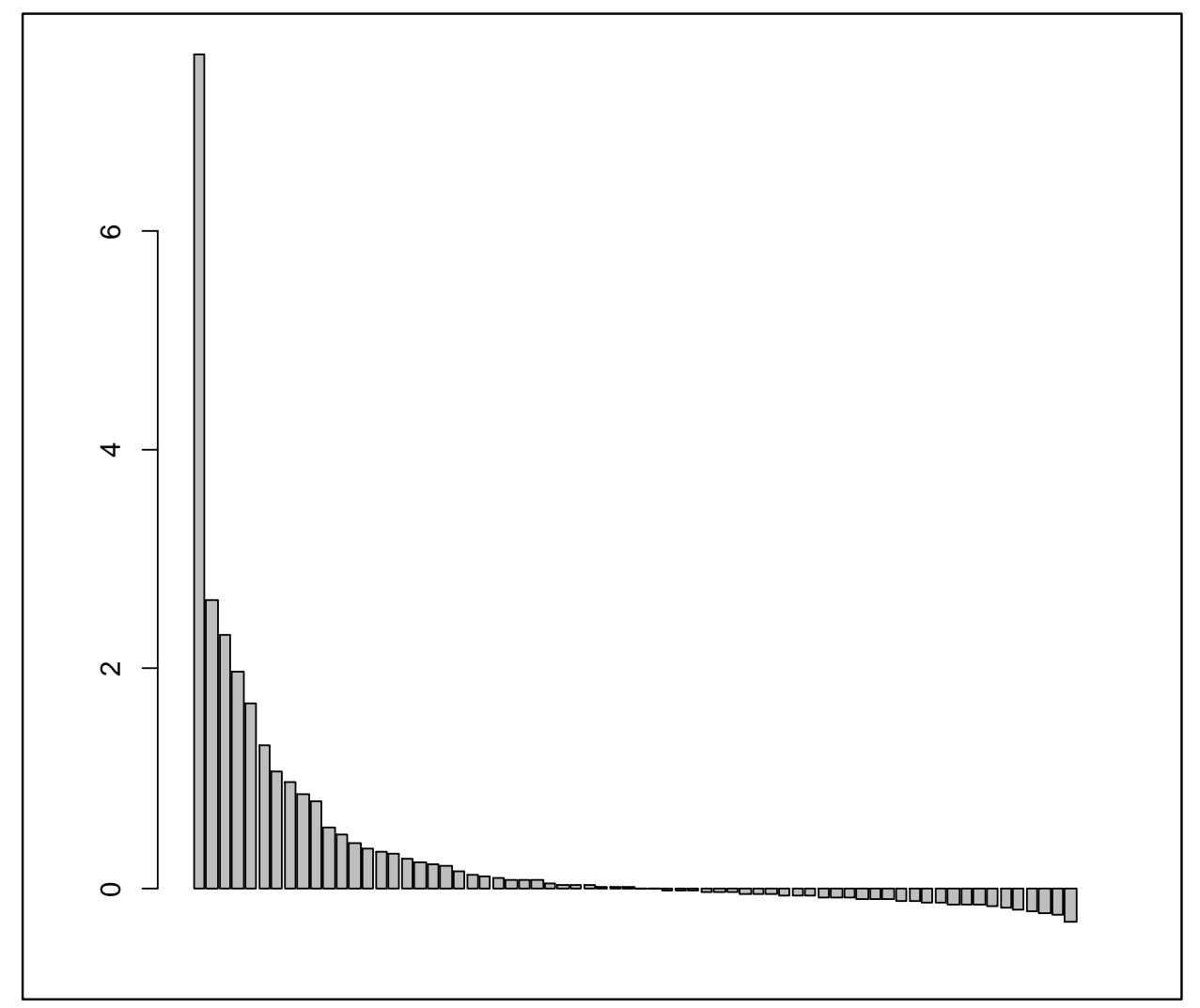

Figure 14 Bar graph showing variance explained by each dimension in PCoA

The PCoA plot (Figure 15) shows the quadrats with similar plant communitites are clustered together. This shows that there is a clear and consistent difference in communities between the two treatment types in species composition. Figure 15 further highlights the relationship between soil moisture and the 20 focal species. 


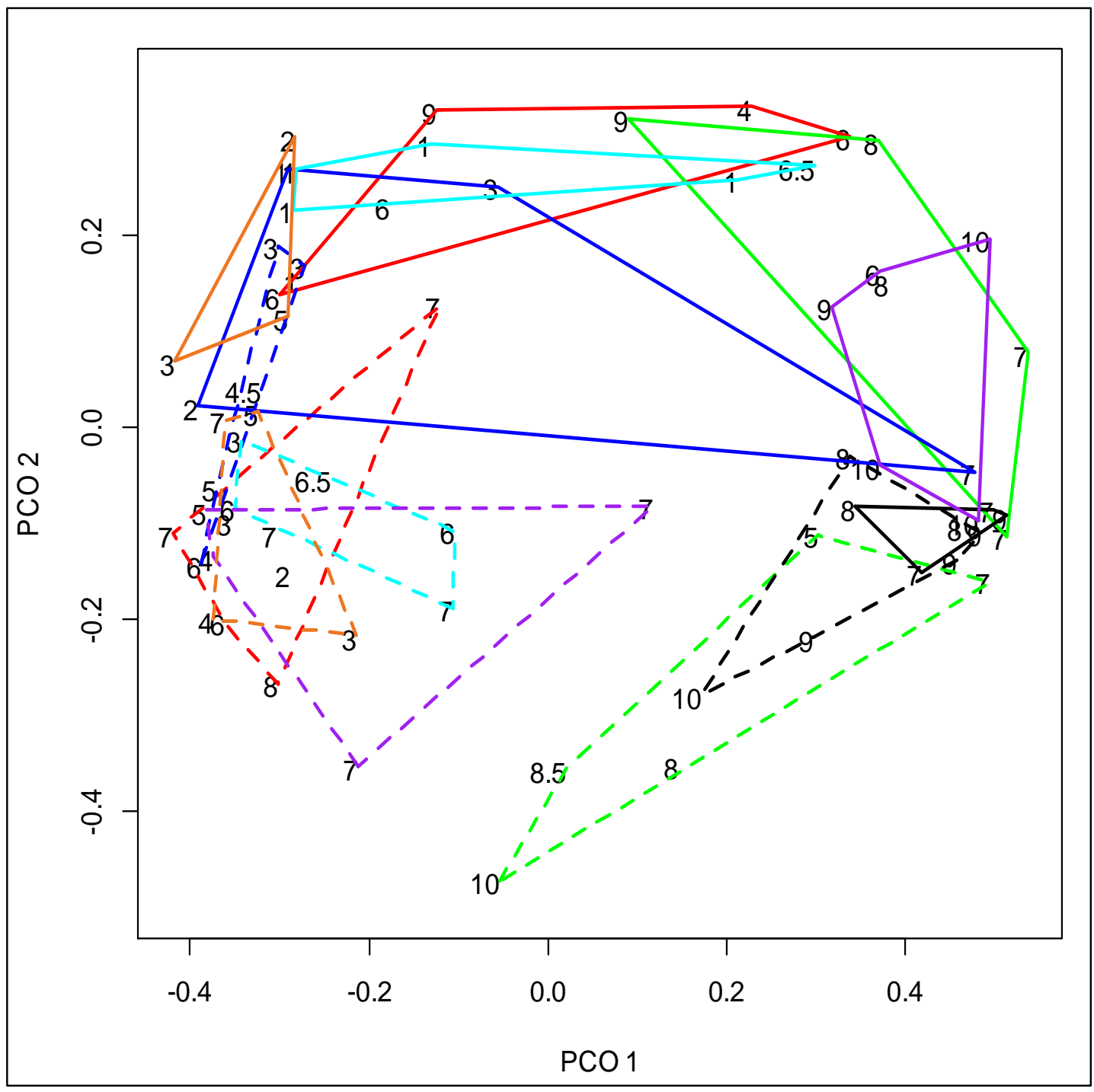

Figure 15 Plot of PCoA with 20 vegetation species, across 68 quadrats. Numbers represent the relative soil moisture score. The solid line polygons code for unscraped Blocks; the dotted line polygons represent scraped Blocks. Each set of quadrats in a particular Block are matching in colour. Red = 3, Green = 5, Black =6, Blue = 7, Aqua = 8, Purple = 9, orange $=10$.

Figure 16 is a PCoA plot, overlaid with the contours of relative soil moisture; it shows a rather even distribution of soil moisture across the blocks. The PCoA biplot (Figure 17) shows the correlation of species for high or low soil moisture and a preference for scraped or unscraped soils. Holcus lanatus and T. pratense are associated with low soil moisture, J. articulatus, I. prolifera and G. maxima are associated with wetter soil moisture, $A$. capillaris and $F$. arundinacea are associated with scraped topsoil, whereas Trifolium repens, Lotus tenuis, Lythrum hyssopifolia and Anthemis cotula are characteristic of unscraped sites. 


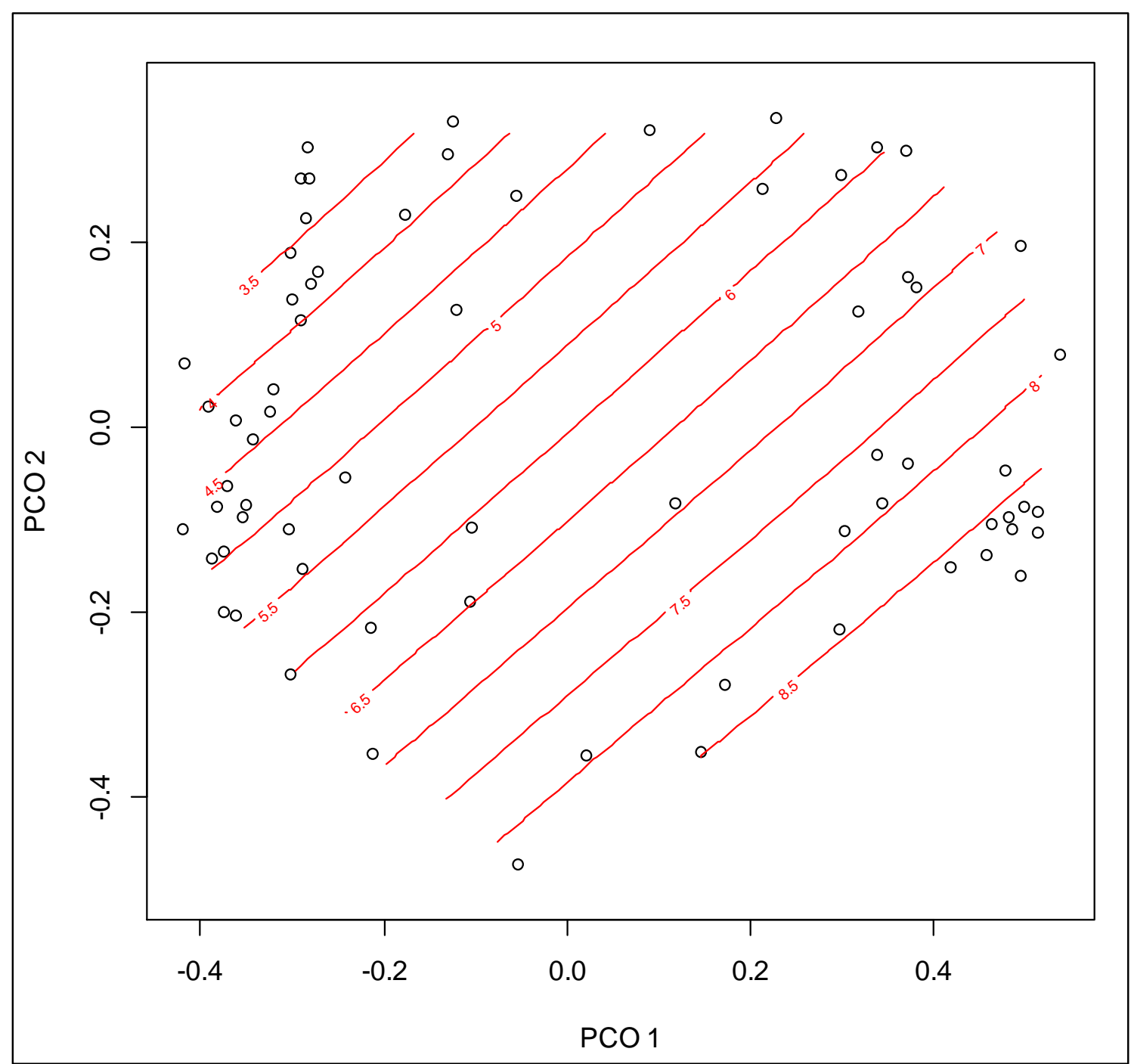

Figure 16 PCoA plot overlaid with a fitted surface of contours for relative soil moisture. 


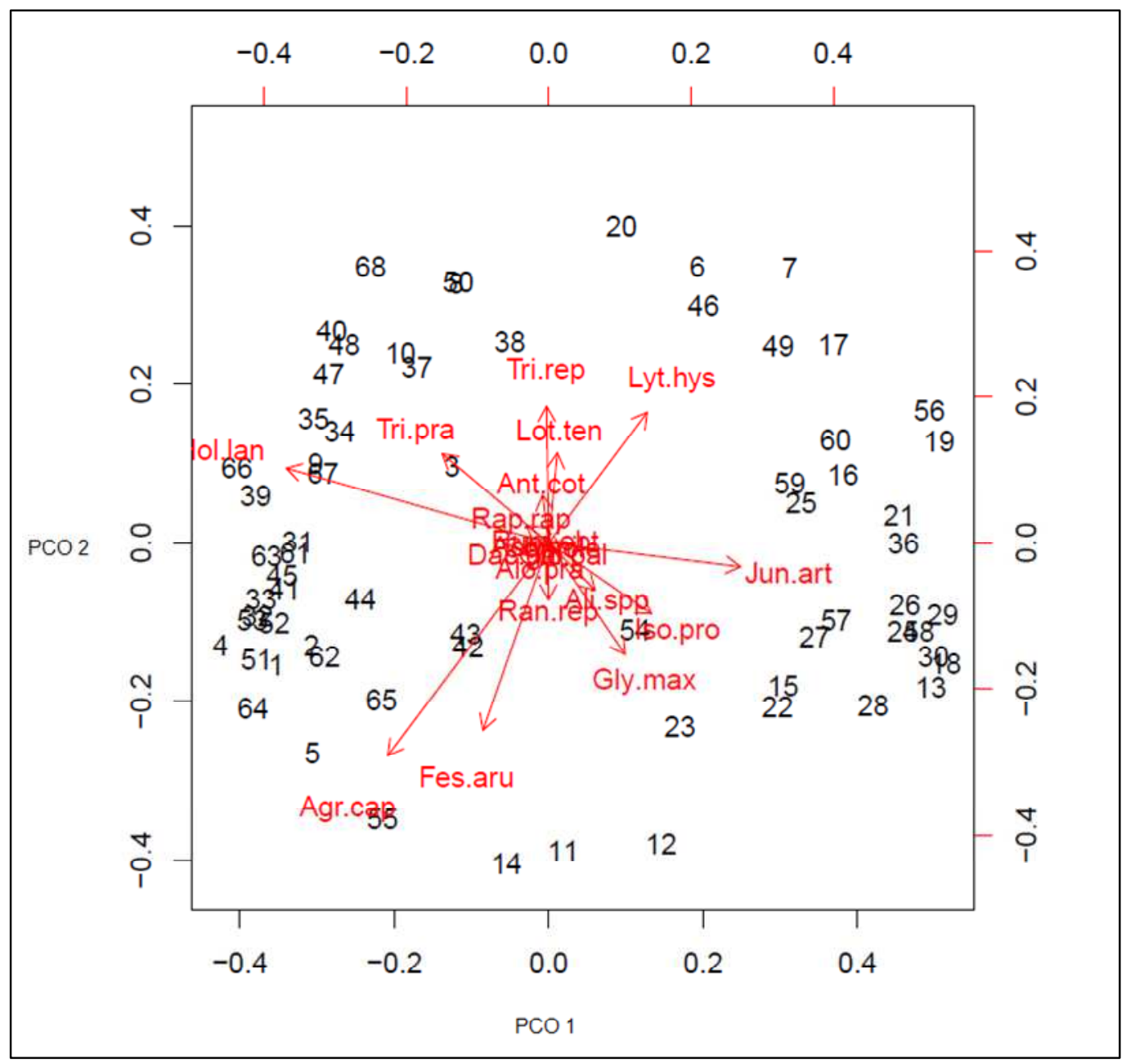

Figure 17 PCoA biplot response variables projected as in PCA with a scaling of 1. Codes are 6 letters representing each species, (genus.species). Numbers represent each plot.

Several of the 20 focal species were found to be significantly related to soil moisture (Table 6). Raphanus raphanistrum, $T$. repens, $H$. lanatus, $A$. cotula, $A$. millefolium and $T$. pratense all have a significant ( $p$-value $<0.05)$ negative correlation with soil moisture. Ranunculus repens, I. prolifera, J. articulatus and Alisma spp. have a significant positive correlation with soil moisture. Soil moisture was not significantly correlated with percentage water cover over a quadrat $(R=0.160$, $p$-value $=0.193)$. 
Table 6 Correlations of relative soil moisture and percent cover of 20 common species. ( ${ }^{*}$ indicate sig. p-value, ${ }^{*}<0.05,{ }^{\star *}<0.01,{ }^{\star \star \star}<0.001, \mathrm{n}=68$ ).

\begin{tabular}{|c|c|}
\hline Species name & Correlation to Soil Moisture \\
\hline Juncus articulatus & $0.439^{* * *}$ \\
\hline Isolepis prolifera & $0.326^{\star *}$ \\
\hline Ranunculus repens & $0.288^{*}$ \\
\hline Alisma spp. & $0.277^{\star}$ \\
\hline Festuca arundinacea & 0.162 \\
\hline Glyceria maxima & 0.159 \\
\hline Sonchus oleraceus & 0.143 \\
\hline Lythrum hyssopifolia & 0.131 \\
\hline Lotus tenuis & 0.071 \\
\hline Alopecurus pratensis & 0.061 \\
\hline Rumex obtusifolius & 0.015 \\
\hline Agrostis capillaris & -0.229 \\
\hline Dactylis glomerata & -0.189 \\
\hline Trifolium pratense & $-0.241^{*}$ \\
\hline Achillea millefolium & $-0.242^{*}$ \\
\hline Trifolium repens & $-0.307^{\star *}$ \\
\hline Anthemis cotula & $-0.333^{\star *}$ \\
\hline Raphanus raphanistrum & $-0.353^{\star *}$ \\
\hline Holcus lanatus & $-0.447^{\star \star \star}$ \\
\hline
\end{tabular}

Four out of the five focal species can be compared with the key indicator species found at Stage one of the Wairio wetland Alisma spp., G. maxima, I. prolifera and H. lanatus (Yorkshire fog, as an alternative to common pasture grasses) (Figure 18A to D). Neither of the native turf species (G. elatinoides and L. perpusilla) were found in the sampling of 
Stage 3. All four species in Figure 18A to D, are best supported by a humpbacked relationship (Model 3). Alisma spp. grows more frequently and abundantly in soils of high soil moisture that have been scraped. Glyceria maxima grows in soils of moderately high soil moisture, with no apparent preference for scraped or unscraped topsoil. Isolepis prolifera grows in high soil moisture, starting from soil moisture of 6 and also shows no preference of topsoil removal. Holcus lanatus grows in relatively lower soil moisture, but has the greatest range out of the four key species; it shows a preference for unscraped topsoil. 


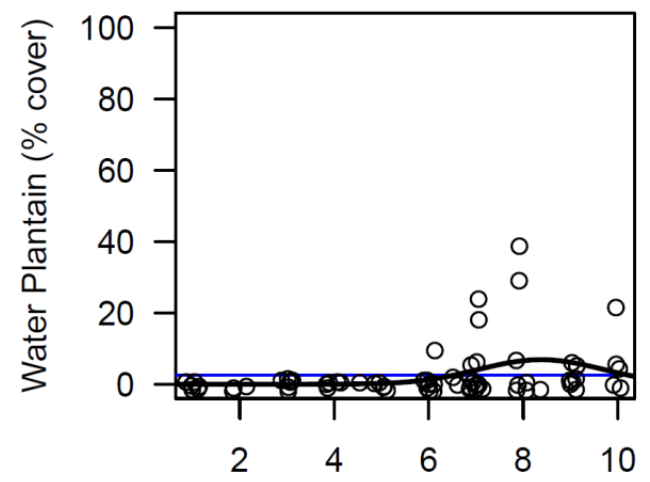

Soil Moisture, Dec 2012

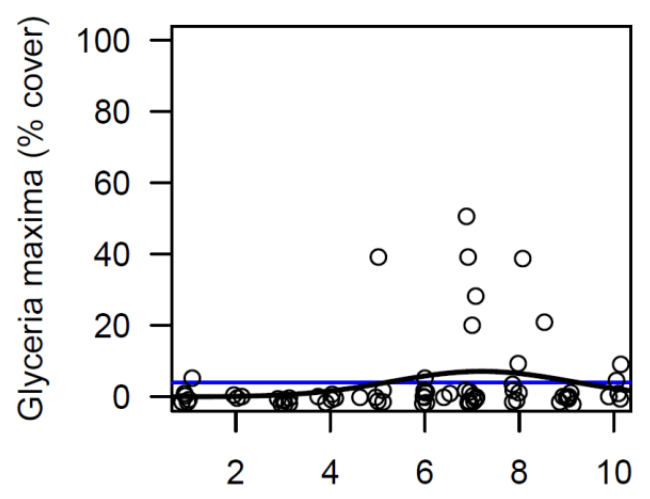

Soil Moisture, Dec 2012

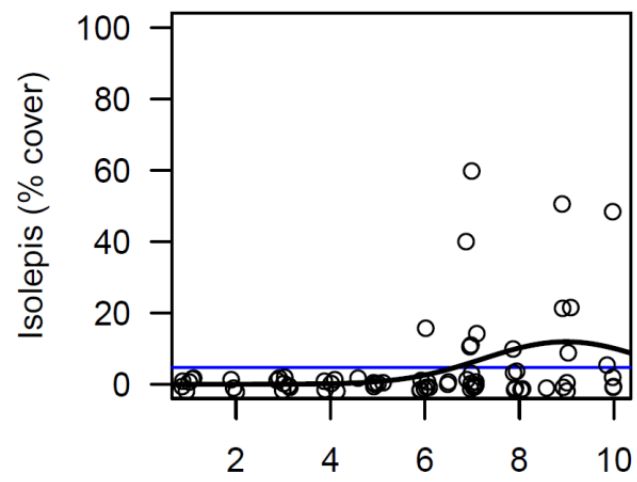

Soil Moisture, Dec 2012

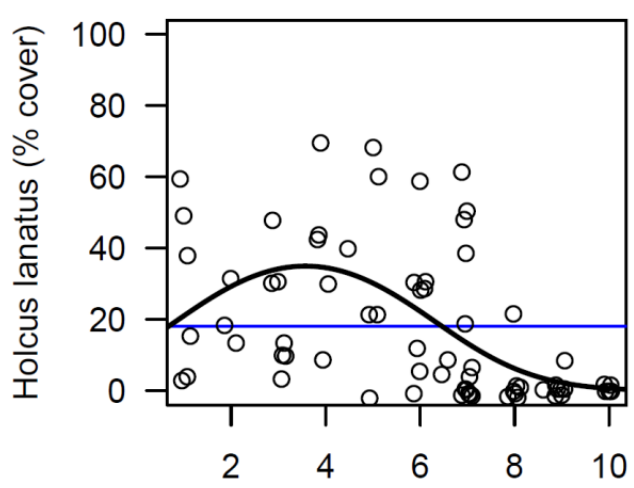

Soil Moisture, Dec 2012

Figure 18 Graphs of potential best-fit niche models describing the percentage cover of each species across pooled data of scraped and unscraped blocks. A) Alisma spp. against soil moisture December 2012. B) /solepis prolifera against soil moisture December 2012. C) G/yceria maxima against soil moisture December 2012. D) Holcus lanatus against soil moisture December 2012. Model 1 = intercept-only (blue), and model 3 = humpbacked relationship (black). The best-supported model (lowest AIC) has been bolded in each qraph. 
There were significant differences found between soil moisture and treatments (scraped or unscraped) when analysed in relation to the most common species (Table 7). The positive beta values for moisture indicate an increase in abundance with soil moisture that positive values for beta of the scraping treatment indicate that the species is more abundant in scraped plots. Percentages of cover of $H$. lanatus, J. articulatus, I. prolifera and $A$. capillaris were affected by soil moisture; and J. articulatus, $A$. capillaris, $F$. arundinacea, $L$. tenuis, $L$. hyssopifolia were significantly affected by treatment. These results are consistent with the PCoA biplot which shows species affected by moisture and/or treatment. A positive beta coefficient for scraping indicates greater abundance of the species than in the scraped areas when compared to the unscraped areas. That means grasses $A$. capillaris and $F$. arundinacea are significantly more abundant in scraped areas; and J. articulatus, L. tenuis and L. hyssopifolia are more significantly abundant in unscraped areas; these results are comparable to results found throughout the rest of the chapter (Table 6, Figure 13, Figure 15, Figure 17 and Figure 18A to D). 
Table 7 GLS model in relation to Moisture, Treatment, of the most common species (* indicate sig. pvalue, $\left.{ }^{*}<0.05,{ }^{* \star}<0.01,{ }^{* \star *}<0.001\right)$.

\begin{tabular}{lllll}
\hline \multirow{2}{*}{ Species } & \multicolumn{2}{c}{ Moisture } & \multicolumn{2}{c}{ Scraping Treatment } \\
\cline { 2 - 5 } & Beta coeff. & p-value & Beta coeff. & p-value \\
\cline { 2 - 5 } Agrostis capillaris & $-0.017^{*}$ & 0.0135 & $0.179^{* * *}$ & 0.0000 \\
Alisma spp. & -0.005 & 0.1527 & -0.032 & 0.0618 \\
Festuca arundinacea & 0.008 & 0.2162 & $0.122^{* * *}$ & 0.0002 \\
Glyceria maxima & -0.005 & 0.3559 & -0.008 & 0.7228 \\
Holcus lanatus & $-0.019^{*}$ & 0.0406 & 0.067 & 0.1044 \\
Isolepis prolifera & $0.016^{* *}$ & 0.0045 & -0.042 & 0.1432 \\
Juncus articulatus & $0.022^{* *}$ & 0.0083 & $-0.012^{* *}$ & 0.0083 \\
Lotus tenuis & 0.002 & 0.5729 & $-0.046^{* *}$ & 0.0040 \\
Lythrum hyssopifolia & 0.008 & 0.1646 & $-0.102^{* * *}$ & 0.0008 \\
Trifolium repens & -0.007 & 0.0856 & -0.028 & 0.0750 \\
Trifolium pratense & -0.013 & 0.0560 & 0.054 & 0.1278 \\
\hline
\end{tabular}

\section{Discussion}

\section{Fine-scale Temporal and Spatial Plant Dynamics along a Hydrological}

\section{Gradient}

As predicted by Whittaker (1967) and Barbour (1980) wetland plant communities display strong zonation patterns as they are subjected to gradients of hydrological stress. This was also true at Wairio wetland. The zonation patterns progress from aquatic species, to turf species, to exotic grass species. Over the two seasonal desiccation periods examined it was found that the most abundant introduced species in low soil moisture 
were common pasture grasses especially $H$. lanatus, $A$. capillaris and $F$. arundinacea as well as the clover $T$. pratense. Water plantain is an invasive competitor in soils that are high in moisture. The comparatively moderate soil moisture species are I. prolifera and G. maxima. Native species G. elatinoides and L. perpusilla are restricted to a small band of highly moist sites, the last zone to be exposed by the retreating water margin. Few invasive species grow in these moist soils (apart from water plantain), so there are fewer competitors for the natives to contend with. In drier soils, invasive grasses (e.g. $H$. lanatus and $F$. arundinacea) can spread easily, giving the vulnerable natives little chance of survival against the more vigorous competitors. The restricted habitat conditions and narrow temporal opportunity for growth of $G$. elatinoides and L. perpusilla make them vulnerable to changing water regimes. This narrow opportunity for growth is during the last stages of summer, when the seasonal wetland is dry enough for this species to grow along the pond perimeter.

\section{Association Between Plant Communities and Soil Moisture}

The four focal species (Alisma spp., G. maxima, I. prolifera and H. lanatus) that were measured in January 2012 in Stage three) displayed comparable results (Figure 18) to the same four focal species measured over summer 2010/2011 in Stage one (Figure 13 A to $E$ and Table 5). Alisma spp., G. maxima and H. lanatus (or pasture grasses) all show similar patterns of preferred moisture levels (relatively high, intermediary and low respectively) and were best described by a humpbacked relationship in both seasons. Isolepis prolifera showed similar patterns of relatively intermediate soil moisture preference; however in the 2010/2011 summer it was best described by a negative linear model and in 2012 a humpbacked relationship. This is probably because a wider range of soil moisture conditions were sampled in Stage three.

\section{Effects of Scraping Topsoil}

Topsoil excavation impacts the plant community; this is shown by the difference in species composition between the two site-preparation methods. Scraping increases the proportion of bare ground and it takes months before any species return to the original density cover. Grass species such as F. arundinacea and $A$. capillaris become significantly more abundant in areas where topsoil has been scraped, whereas species L. tenuis, T. repens, A. cotula and L. hyssopifolia were more abundant in unscraped soils. Our results differ from Rasran et al. (2007) who studied riparian fen grasslands in Germany. Their study found that removal of topsoil suppressed growth of all pasture grasses; while our results found that scraping had a significantly positive effect on the 
abundance of two grass species ( $F$. arundinacea and $A$. capillaris). Perhaps our results differ from Rasran et al. (2007) because in addition to topsoil removal, they also added the treatment of hay transfer of diaspore-rich material. This would have assisted in the establishment of key species and the suppression of agricultural grasses. Areas at Wairio wetland where the scraped and bare topsoil were left to the elements (apart from the planted natives) had no assistance in establishment of other key species, so abundant grass seeds could flourish. Our results, however, are consistent with results from Patzelt et al. (2001) and Norbert and Otte (2003), who studied wet fen meadows in Germany. They found topsoil removal created favourable conditions for seedling recruitment of exotic invasive species as well as planted native species; competition from established vegetation has proven to be a key constraint controlling growth and survival of other seedlings.

Norbert and Otte (2003) found that the temporal and spatial component of the invasive weed regeneration is considerably enlarged by the partial removal of the topsoil seed bank and abstraction of established vegetation. Logically, one would expect scraping to temporarily reduce total plant cover and favour the establishment of ruderal species (especially annuals) with a plentiful supply of seed in the surrounding area.

\section{Conclusions}

Topsoil scraping in the high soil moisture areas leads to a plant community with greater native density, with the dominant species being Alisma spp. and I. prolifera, scraping in relatively low soil moisture, however, encourages the grass weed species to grow. Scraping, regardless of soil moisture, initially creates a more sparse plant community, thus reducing plant competition and allowing for more successful native revegetation (including reintroduced taxa), or the establishment of native turf species ( $G$. elatinoides and $L$. perpusilla). The recommendation of topsoil scraping is consistent with results from Rasran et al. (2007), whose study on northern German wetlands found the establishment of native focal species to be most successful when combined with topsoil removal, continuous weed control management, as well as hay transfer.

Now that we have a greater understanding of the coverage of invasive species across different moisture levels, managers at Wairio wetland can specifically manage the species across different environments to decrease competition with native species. Sites with exotic species such as Alisma spp., J. articulatus and G. maxima could be controlled to reduce competition with native turf species (generally high moisture areas). Controlling emergent weeds in an aquatic environment is more complicated, but can 
consist of mechanical control (such as hand weeding or dredging), or water level manipulations (Lancar and Krake, 2002). Grasses growing in relatively low moisture sites can be managed for successful establishment of native woody vegetation, with further recommendations from Chapter three. 


\section{References}

Barbour, M.G., Burk, J.H., and Pitts, W.D, 1980. Terrestrial Plant Ecology. Benjamin/Cummings, London, UK .

Brock, M.A., Britton, D.L., 1995. The role of seed banks in the revegetation of Australian temporary wetlands., in: Wheeler, B.D., Shaw, S. C., Fojt, W. and Robertson, R. A. (Ed.), Restoration of Temperate Wetlands. John Wiley \& Sons, Cambridge.

Bunn, S.E., Boon, P. I., Brock, M. A. and Schofield, N. J., 1997. National Wetlands $R$ and $D$ Program Scoping Review. Land and Water Resources Research and Development Corporation, Paper 01/97, Canberra.

Burnham, K.P., Anderson, D.R., 2002. Model Selection and Mulitmodel Inference: A Practical Information Theoretic Appriach. Springer - Verlag, New York.

Casanova, M.T., Brock, M.A., 2000. How do depth, duration and frequency of flooding influence the establishment of wetland plant communities?. Plant Ecology 147, 237-250.

Champion, P.D., 1998. Selective control of weeds in New Zealand wetlands 51st New Zealand Plant Protection Conference, Hamilton. pp. 251-254.

Dormann, C.F., McPherson, J.M., Araújo, M.B., Bivand, R., Bolliger, J., Carl, R., Davies, R.G., Hirzel, A., Jetz, W., Kissling, D., Kühn, I., Ohlemüller, R., Peres-Neto, P.R., Reineking, B., Schröder, B., Schurr, F.M., and Wilson, R. , 2007. Methods to account for spatial autocorrelation in the analysis of species distributional data: a review. Ecography 30, 609-628.

Ecke, F., Rydin, H., 2000. Succession on a land uplift coast in relation to plant strategy theory. Annales Botanici Fennici 37, 163-171.

Goldberg, D.E., 1982. The distribution of evergreen and deciduous trees relative to soil type: an example from the Sierra Madre, Mexico, and a general model. Ecology 63, 942-951.

Grace, J.B., 2001. The roles of community biomass and species pools in the regulation of plant diversity. Oikos 92, 193-207.

Grace, J.B., Wetzel, R.G., 1981. Habitat partitioning and competitive displacement in catails (Typha): experimental field studies. American Naturalist 118, 463-474.

Greater Wellington Regional Council., 2010. Map of Wairio Wetlands, Ducks Unlimited NZ. www.ducks.org.nz. Downloaded April 2011.

Grime, J.P., 1963. An ecological investigation at a junction between two plant communities in Coombsdale on the Derbyshire limestone. Ecology 51, 391-402.

Grime, J.P., 1977. Evidence for the existence of three primary stategies in plants and its relevance to ecological and evolutionary theory. American Naturalist 111, 11691194.

Grime, J.P., 1979. Plant Strategies and Vegetation Processes, Wiley, Chichester. 
Grime, J.P., 1987. Dominant and subordinate components of plant communities: implications for succession, stability and diversity, in: Gray, A.J., Crawley, M.J., and Edwards, P.J. (Eds.), Colonization, succession and stability. Blackwell Science Publication, Oxford, pp. 413-428.

Gurevitch, J., 1986. Competition and the local distribution of the grass Stipa neomexicana. Ecology 67, 46-57.

Greater Wellington Regional Council (GWRC)., 2003. Wetland Action Plan. http://www.gw.govt.nz/assets/councilpublications/Environment\%20Management 200306 11 095644.pdf. Downloaded April 2011.

Hutchinson, G., 1975. A Treatise on Limnology. Wiley, New York

Johnson, P., Rogers, G., 2003. Ephemeral wetlands and their turfs in New Zealand, Department of Conservation, Wellington.

Keddy, P.A., 2006. Wetland Ecology: Principles and Conservation 2ed. Cambridge University Press, Cambridge.

Lancar, L., Krake, K., 2002. Aqautic Weeds and their Management, International Commission on Irrigation and Drainage. http://www.icid.org/weed report.pdf. Downloaded Feburary 2012.

Leck, M.A., 1989. Wetland seed banks in: Leck, M.A., Parker, V.T., and Simpson, R.L. (Eds.), Ecology of soil seed banks. Academic Press, San Diego, CA.

Norbert, H., Otte, A., 2003. Restoration of a species-rich flood meadow by topsoil removal and diaspore transfer with plant material. Applied Vegetation Science 6, 131140.

Odland, A., del Moral, R., 2002. Thirteen years of wetland vegetation succession following a permanent drawdown, Myrkdalen Lake, Norway Plant Ecology 162, 185-198.

Patzelt, A., Wild, U., Pfadenhauer, J., 2001. Restoration of Wet Fen Meadows by Topsoil Removal: Vegetation Development and Germination Biology of Fen Species. Restoration Ecology 9, 127-136.

Ramseier, D., 2000. Why remove topsoil for fen restoration? Influence of water table, nutrients and competitors on the establishment of four selected plant species. Bulletin of Geobotanical Institute ETH 66, 25-35.

Rasran, L., Vogt, K., and Jensen, K., 2007. Effects of topsoil removal, seed transfer with plant material and moderate grazing on restoration of riparian fen grasslands. Applied Vegetation Science 10, 451-460.

Seabloom, E.W.H., W. S., Reichman, O.J., and Tilman, D., 2003. Invasion, competitive dominance, and resource use by exotic and native California grassland species. Proceedings of the National Academy of Sciences USA 100, 13384-13389.

Sharitz, R.R., McCorkmick, J.F., 1973. Population dynamics of two competing annual plant species. Ecology 54, 723-740. 
Silander, J.A., Antonovics, J., 1982. Analysis of interspecific competition in a coastal plant community, a perturbation approach. Nature 298, 557-560.

Silbery, T., 2011. Personal communication with Tony Silbery: biodiversity ranger for the Deparment of Conservation, Wellington Hawke's Bay conservancy, December 2012.

Snow, A.A., Vince, S.W., 1984. Plant zonation in an Alaskan salt marsh. II. An experimental study of the role of edaphic conditions. Ecology 72, 669-684.

Tilman, D., 1982. Resources competition and community structure. Monographs in Population Biology. Princeton University Press Princeton, New Jersey.

van der Valk, A.G., Penderson, R.L., 1989. Seed banks and the management and restoration of natural vegetation., in: Leck, M.A., Parker, V.T., and Simpson, R.L. (Eds.), Ecology of Soil Seed Banks. Academic Press, Inc.,San Diego, California, pp. 329-346.

Whittaker, R.H., 1956. Vegetation of the Great Smokey Mountains. Ecological Monographs 26, 1-80. 264.

Whittaker, R.H., 1967. Gradient Analysis of Vegetation. Biology Reviews 47, 207-

Wellington Model Aeroplane Club (WMAC), 2011. Rayner's Gladstone Weather. http://www.wmac.org.nz/gladstoneweather/. Downloaded March 2011. 


\section{Appendix 2}

\section{Appendix 2.1}

Table 8 Common and scientific names of plant species found at the greater Lake Wairarapa wetlands. Status data from (New Zealand Plant Conservation Network, (2010).

\begin{tabular}{|c|c|c|c|}
\hline Common name & Scientific name & $\begin{array}{l}\text { Native or } \\
\text { exotic }\end{array}$ & Threatened status \\
\hline $\begin{array}{l}\text { Maniototo button } \\
\text { daisy }\end{array}$ & Leptinella maniototo & Native & Data deficient \\
\hline None known & Crassula ruamahanga & Native & Naturally uncommon \\
\hline None known & Lobelia carens & Native & Nationally endangered \\
\hline Pillwort & Pilularia novae-zelandiae & Native & Naturally uncommon \\
\hline Glosso & Glossostigma elatinoides & Native & Non threatened \\
\hline Hypsela & $\begin{array}{l}\text { Hypsela rivalis now } \\
\text { classified as Lobelia } \\
\text { ionantha }\end{array}$ & Native & Declining \\
\hline Water brome & Amphibromus fluitans & Native & Nationally endangered \\
\hline Kahikatea & Dacrycarpus dacrydioides & Native & Non threatened \\
\hline Cabbage tree & Cordyline australis & Native & Non threatened \\
\hline Totara & Podocarpus totara & Native & Non threatened \\
\hline Kowhai & Sophora microphylla & Native & Non threatened \\
\hline Reed sweet-grass & Glyceria maxima & Exotic & \\
\hline Maori bedstraw & Gallium propinquum & Native & Non threatened \\
\hline Water plantains & Alisma spp. & Exotic & \\
\hline None known & Isolepis prolifera & Native & Non threatened \\
\hline None known & Lobelia perpusilla & Native & Naturally Uncommon \\
\hline
\end{tabular}




\section{Appendix 2.2}

Table 9 GPS co-ordinates ( $\pm 7 \mathrm{~m}$ ) (NZMG) from Quadrates at Stage 1, Wairio Wetland.

\begin{tabular}{ccc}
\hline & & \\
Transect number & Quadrat number & GPS co-ordinate \\
& & \\
$\mathbf{1}$ & $\mathbf{1}$ & $2697885.9,5992726.2$ \\
$\mathbf{1}$ & $\mathbf{2}$ & $2697882.2,5992746.7$ \\
$\mathbf{1}$ & $\mathbf{3}$ & $2697893.2,5992737.1$ \\
$\mathbf{1}$ & $\mathbf{4}$ & $2697895.9,5992735.2$ \\
$\mathbf{1}$ & $\mathbf{5}$ & $2697890.6,5992744.6$ \\
$\mathbf{1}$ & $\mathbf{6}$ & $2697900.4,5992746.2$ \\
$\mathbf{1}$ & $\mathbf{7}$ & $2697901.9,5992751.7$ \\
$\mathbf{1}$ & $\mathbf{8}$ & $2697899.2,5992755.5$ \\
$\mathbf{1}$ & $\mathbf{9}$ & $2697920.1,5992751.2$ \\
$\mathbf{2}$ & $\mathbf{1 0}$ & $2697921.5,5992751.2$ \\
$\mathbf{2}$ & $\mathbf{1}$ & $2697905.7,5992734.9$ \\
$\mathbf{2}$ & $\mathbf{2}$ & $2697907.0,5992729.4$ \\
$\mathbf{2}$ & $\mathbf{3}$ & $2697899.0,5992744.4$ \\
$\mathbf{2}$ & $\mathbf{4}$ & $2697900.5,5992751.7$ \\
$\mathbf{2}$ & $\mathbf{5}$ & $2697896.5,5992759.3$ \\
$\mathbf{2}$ & $\mathbf{6}$ & $2697892.4,5992761.2$ \\
$\mathbf{2}$ & $\mathbf{7}$ & $2697888.5,5992774.3$ \\
$\mathbf{2}$ & $\mathbf{8}$ & $2697887.2,5992776.2$ \\
$\mathbf{2}$ & $\mathbf{9}$ & $2697902.4,5992770.2$ \\
& $\mathbf{1 0}$ & $2697926.6,5992786.3$ \\
\hline & & \\
\hline
\end{tabular}




\section{Appendix 2.3}

Table 10 Dates of visits to Stage 1 at the Wairio Wetland.

\begin{tabular}{cl}
\hline Visit number & Date \\
\hline 1 & December 29, 2010 \\
2 & January 13, 2011 \\
3 & January 26, 2011 \\
4 & February 07, 2011 \\
5 & February 23, 2011 \\
6 & March 9, 2011 \\
7 & March 23, 2011 \\
\hline
\end{tabular}




\section{Appendix 2.4}

Table 11 GPS co-ordinates (NZMG) $( \pm 7 \mathrm{~m}$ ) from Stage 3 Wairio Wetland. (S = Scraped, $\mathrm{U}=$ Unscraped.)

\begin{tabular}{|c|c|c|}
\hline Block number & $\mathrm{S} /$ and $\mathrm{U}$ & GPS Co-ordinates (E/N) \\
\hline 3 & $\mathrm{~S}$ & $2699385.9,5993468$ \\
\hline 3 & $S$ & $2699329.3,5993439.9$ \\
\hline 3 & $S$ & $2699329.1,5993432.5$ \\
\hline 3 & $S$ & $2699328.6,5993415.8$ \\
\hline 3 & $S$ & $2699357.2,5993439.1$ \\
\hline 3 & $U$ & $2699343.2,5993439.5$ \\
\hline 3 & $U$ & $2699329.2,5993438$ \\
\hline 3 & $U$ & $2699329.5,5993449.1$ \\
\hline 3 & $U$ & $2699329.5,5993451$ \\
\hline 3 & $U$ & $2699343.6,5993452.5$ \\
\hline 5 & $S$ & $2699418.9,5993665.3$ \\
\hline 5 & $S$ & $2699376.5,5993644.2$ \\
\hline 5 & $S$ & $2699376.7,5993653.4$ \\
\hline 5 & $S$ & $2699362.5,5993646.4$ \\
\hline 5 & $S$ & $2699363.3,5993674.1$ \\
\hline 5 & $U$ & $2699433.2,5993676$ \\
\hline 5 & $U$ & $2699433.2,5993677.9$ \\
\hline 5 & $U$ & $2699418.9,5993663.4$ \\
\hline 5 & $U$ & $2699418.9,5993663.4$ \\
\hline 5 & $U$ & $2699419.1,5993670.9$ \\
\hline 6 & $S$ & $2699433.2,5993676$ \\
\hline 6 & $S$ & $2699433.1,5993674.2$ \\
\hline 6 & $S$ & $2699419.3,5993680.1$ \\
\hline 6 & $S$ & $2699405.1,5993671.2$ \\
\hline 6 & $S$ & $2699405.3,5993676.8$ \\
\hline 6 & $U$ & $2699405.7,5993695.3$ \\
\hline 6 & $U$ & $2699405.7,5993695.3$ \\
\hline 6 & $U$ & $2699405.8,5993699$ \\
\hline 6 & $U$ & $2699391.7,5993691.9$ \\
\hline 6 & $U$ & $2699391.4,5993680.8$ \\
\hline 7 & $S$ & $2699543.8,5993628.7$ \\
\hline 7 & $\mathrm{~S}$ & $2699529.6,5993621.7$ \\
\hline
\end{tabular}




\begin{tabular}{|c|c|c|}
\hline 7 & $S$ & $2699515.2,5993603$ \\
\hline 7 & $S$ & $2699515.5,5993616.5$ \\
\hline 7 & $S$ & $2699515.5,5993614.7$ \\
\hline 7 & $U$ & $2699515.6,5993620.2$ \\
\hline 7 & $U$ & $2699501.9,5993631.7$ \\
\hline 7 & $U$ & $2699515.8,5993627.6$ \\
\hline 7 & $U$ & $2699530,5993634.7$ \\
\hline 7 & $U$ & $2699530.1,5993638.4$ \\
\hline 8 & $\mathrm{~S}$ & $2699571.2,5993609.5$ \\
\hline 8 & $S$ & $2699557.4,5993615.4$ \\
\hline 8 & $\mathrm{~S}$ & $2699571.2,5993607.7$ \\
\hline 8 & $\mathrm{~S}$ & $2699556.8,5993593.2$ \\
\hline 8 & $\mathrm{~S}$ & $2699556.9,5993596.9$ \\
\hline 8 & $U$ & $2699542.9,5993595.4$ \\
\hline 8 & $U$ & $2699529.4,5993614.3$ \\
\hline 8 & $U$ & $2699543.5,5993619.5$ \\
\hline 8 & $U$ & $2699557.4,5993613.6$ \\
\hline 8 & $U$ & $2699557.4,5993615.4$ \\
\hline 9 & $\mathrm{~S}$ & $2699499.9,5993552.1$ \\
\hline 9 & $S$ & $2699486.4,5993571$ \\
\hline 9 & $S$ & $2699500.4,5993574.3$ \\
\hline 9 & $\mathrm{~S}$ & $2699500.7,5993583.6$ \\
\hline 9 & $\mathrm{~S}$ & $2699514.6,5993581.4$ \\
\hline 9 & $U$ & $2699514.6,5993581.4$ \\
\hline 9 & $U$ & $2699514.6,5993581.4$ \\
\hline 9 & $U$ & $2699500.4,5993574.3$ \\
\hline 9 & $U$ & $2699556.7,5993585.8$ \\
\hline 9 & $U$ & $2699500.6,5993581.7$ \\
\hline 10 & $S$ & $2699444,5993551.7$ \\
\hline 10 & $\mathrm{~S}$ & $2699444,5993551.7$ \\
\hline 10 & $\mathrm{~S}$ & $2699444,5993551.7$ \\
\hline 10 & U & $2699472.2,5993562.1$ \\
\hline 10 & $U$ & $2699472.1,5993558.4$ \\
\hline 10 & $U$ & $2699444,5993551.7$ \\
\hline 10 & $U$ & $2699444.5,5993572.1$ \\
\hline 10 & $U$ & $2699444.2,5993561$ \\
\hline
\end{tabular}




\section{Appendix 2.5}

Table 12 Species list for Association between plant communities and soil moisture ( ${ }^{*}$ indicate deleted from statistical analysis as $<3$ populations found in quadrats).

\begin{tabular}{|c|c|}
\hline Common name & Scientific name \\
\hline Aquatic forget-me-not* & Myosotis laxa \\
\hline Bind weed ${ }^{*}$ & Calystegia tuguriorium \\
\hline Blackberry * & Rubus fruticosus \\
\hline Blue sweet grass* & Glyceria declinata \\
\hline Chatham Island starwort* & Callitriche petriei \\
\hline Cocksfoot grass & Dactylis glomerata $L$. \\
\hline Common bent & Agrostis capillaris \\
\hline Common yarrow & Achillea millefolium \\
\hline Creeping buttercup & Ranunculus repens \\
\hline Dock & Rumex obtusifolius \\
\hline Dog rose* & Rosa canina \\
\hline Hyssop loosestrife & Lythrum hyssopifolia \\
\hline Jointed rush & Juncus articulatus \\
\hline Marsh bedstraw & Gallium palustre \\
\hline Meadow foxtail & Alopecurus pratensis \\
\hline Narrow-leaved birdsfoot trefoil & Lotus tenuis \\
\hline None known & Isolepis prolifera \\
\hline Rush species* & Juncus sp. \\
\hline Perennial ryegrass* & Lolium perenne \\
\hline Red clover & Trifolium pratense \\
\hline Reed sweet grass & Glyceria maxima \\
\hline Rib-wort plantain * & Plantago lanceolata \\
\hline Scotch thistle ${ }^{*}$ & Cirsium vulgare \\
\hline Smooth sow-thistle & Sonchus oleraceus \\
\hline Stinking chamomile & Anthemis cotula \\
\hline Tall fescue & Schedonorus arundinaceus \\
\hline Toad rush* & Juncus bufonius \\
\hline Water plantain & Alisma spp. \\
\hline White clover & Trifolium repens \\
\hline Wild radish & Raphanus raphanistrum \\
\hline Yorkshire fog & Holcus lanatus \\
\hline
\end{tabular}


Appendix 2.6

Table 13 Date of each visit to site and the average daily sunshine hours and average daily rainfall (averaged from the $\sim$ two weeks prior to visit).

\begin{tabular}{ccccc}
\hline Visit & Date of visit & $\begin{array}{c}\text { Days since last } \\
\text { visit }\end{array}$ & $\begin{array}{c}\text { Average Daily } \\
\text { Sunshine (hours) }\end{array}$ & $\begin{array}{c}\text { Average Daily } \\
\text { Rainfall (mm) }\end{array}$ \\
\hline 1 & 29th December 2010 & NA & 5.62 & 1.46 \\
2 & 13th January 2011 & 15 days & 7.96 & 0.40 \\
3 & 26th January 2011 & 13 days & 6.25 & 7.07 \\
4 & 7th February 2011 & 13 days & 7.01 & 0.36 \\
5 & 23rd February 2011 & 16 days & 6.06 & 0.00 \\
6 & 9th March 2011 & 14 days & 4.69 & 0.00 \\
7 & 23rd March 2011 & 13 days & 5.94 & 3.90 \\
& & & \\
\hline
\end{tabular}


Appendix 2.7

Table 14 Species listed as Pasture Grasses, Stage 1, Wairio Wetland (Enright et al., 2008).

\begin{tabular}{ll}
\hline Common name & Scientific name \\
\hline Browntop & Agrostis capillaries \\
Creeping bent & Agrostis stolonifera \\
Meadow foxtail & Alopecurus pratensis \\
Cocksfoot & Dactylis glomerata \\
Glaucous sweet grass & Glyceria declinata \\
Yorkshire fog & Holcus lanatus \\
Perrenial rye grass & Lolium perenne \\
Phalaris & Phalaris aquatica \\
Tall fescue & Schedonorus \\
& arundinaceus \\
\hline
\end{tabular}




\section{INVESTIGATION INTO THE PROCESSES INFLUENCING THE ESTABLISHMENT AND SURVIVAL OF NATIVE WOODY VEGETATION AT WAIRIO WETLAND}

\section{Introduction}

Natural succession from grasslands to a tree or shrub dominated environment is a stochastic process which results from the behaviour of component populations and species (Chazdon, 2008). The invasion of woody plants into grasslands is initially slow, but subsequent displacement of grassland vegetation can be rapid (Siemann and Rogers, 2003). The initial woody invaders create a series of interactions that accelerate the invasion of the late successional woody species (Petranka and McPherson, 1979). However, if regular disturbances occur (i.e. dominance of introduced species (Zedler, 2000), flooding, tectonic movement, or fire (Walker and Willig, 1999)), these accelerating interactions can be disturbed, preventing natural succession (Walker and Del Moral, 2003). Therefore, in environments where exotic species dominate, succession of native species is halted. Succession is important in the development and evolution of any ecosystem structure (Gren et al., 1994). Including wetlands, it influences soil pH, oxygen availability and nutrient flux (Gren et al., 1994), modifying the hydrological conditions by trapping sediment and interrupting water flow (Gosselink and Turner, 1978). In turn, 
these processes are the basis for a wetlands biological development, primary productivity and plant species composition (Odum, 1983; Holling, 1986; Ewel, 1991).

Ecological restoration commonly involves initiating, reversing, redirecting or accelerating vegetation succession (Luken, 1990). Succession can be initiated by introducing woody plants and establishing cover crops that can resist invasion (Zedler, 2005). Restoration ecologists seek to create a mature natural community over a short time (Zedler, 2000). Rather than allowing progressive succession, sites that are subject to ecorestoration management often lose introduced plant species suddenly and uniformly sized native species appear. Such unnatural occurrences can negatively affect the environment (i.e. attract herbivores en masse) (Cramer et al., 2008); however, this restoration approach can quickly elevate the degraded ecosystem to a state of improved ecosystem services and biodiversity (Chazdon, 2008).

When considering ecological restoration, there are several environmental obstacles that can slow an ecosystems recovery, however, the primary factor in many restoration projects is obtaining sufficient funds (King, 1991; Holl and Howart, 2000). The high cost of restoration is rarely documented (Edwards and Abivardi, 1997). Holl and Howart (2000) suggest disregarding costs in restoration could be for four reasons adversity by restorationists to quantifying environmental values in terms of economics; economists and ecologists using different language and modelling techniques (Hall 1992); restoration and economics often being viewed as opposing forces and the difficulty of recording costs (Edwards and Abivardi, 1997). If restoration projects are to succeed, it is important, that even with these obstacles, understanding is gained from both ecology and economics (Holl and Howart, 2000).

There are five factors crucial to ensuring ecological restoration projects are sustainable accuracy in planning, budgeting and implementation (Aronson, 2006); and selecting cost-effective methods and techniques (United States Environmental Protection Agency, 1995). Management questions and issues have been widely discussed by consultants, academics and policy makers. While their research has widely agreed on several key issues in regards to restoration (Office of Wetlands Protection, 1989), there are still doubts regarding exact management techniques and constraints in restoring degraded sites.

The objective of this study was to conduct scientific research to inform the management and ecological restoration objectives of Wairio wetland. Specifically, to commence 
investigating the processes that influence the establishment and survival of native woody vegetation in the restoration area typical of historical swamp forest and analysing their cost-effectiveness. The ecological mechanisms relevant to replanting include plant competition, facilitation, disturbance, succession trajectories and their interaction with abiotic conditions. This study was designed and implemented as a large-scale manipulative field experiment involving the planting of $\sim 2,500$ native trees subject to different methods of site preparation and after-care to determine the best and most costeffective combination of treatments for successful establishment of tree saplings. The survival and growth was measured over the first six months and protocols developed for longer-term monitoring and follow up studies (Chapter four).

\section{Methodology}

\section{Study Site}

This research was conducted during 2011 at one site of the Wairio wetland restoration, Lake Wairarapa (Figure 19). The wetland is co-managed by the Department of Conservation (hereafter regarded as DOC) and Ducks Unlimited NZ (hereafter regarded as DU). The 1960's Lower Wairarapa Development Scheme negatively affected the Wairio wetland ecosystem; it was drained and cleared of trees, with invasive willow trees planted for erosion control. Significant ecological restoration began in 2005 with DOC and DU combining resources. Three areas fenced off (between 5.6 ha and $8.3 \mathrm{ha}$ ) within the 133-ha wetland, have been the focus of restoration thus far. Attempts at restoration of native plants within the Wairio wetland before this research have been met with mixed success. It has been estimated that between $50 \%$ and $75 \%$ of the planted trees have survived (Silbery, personal comms.). 


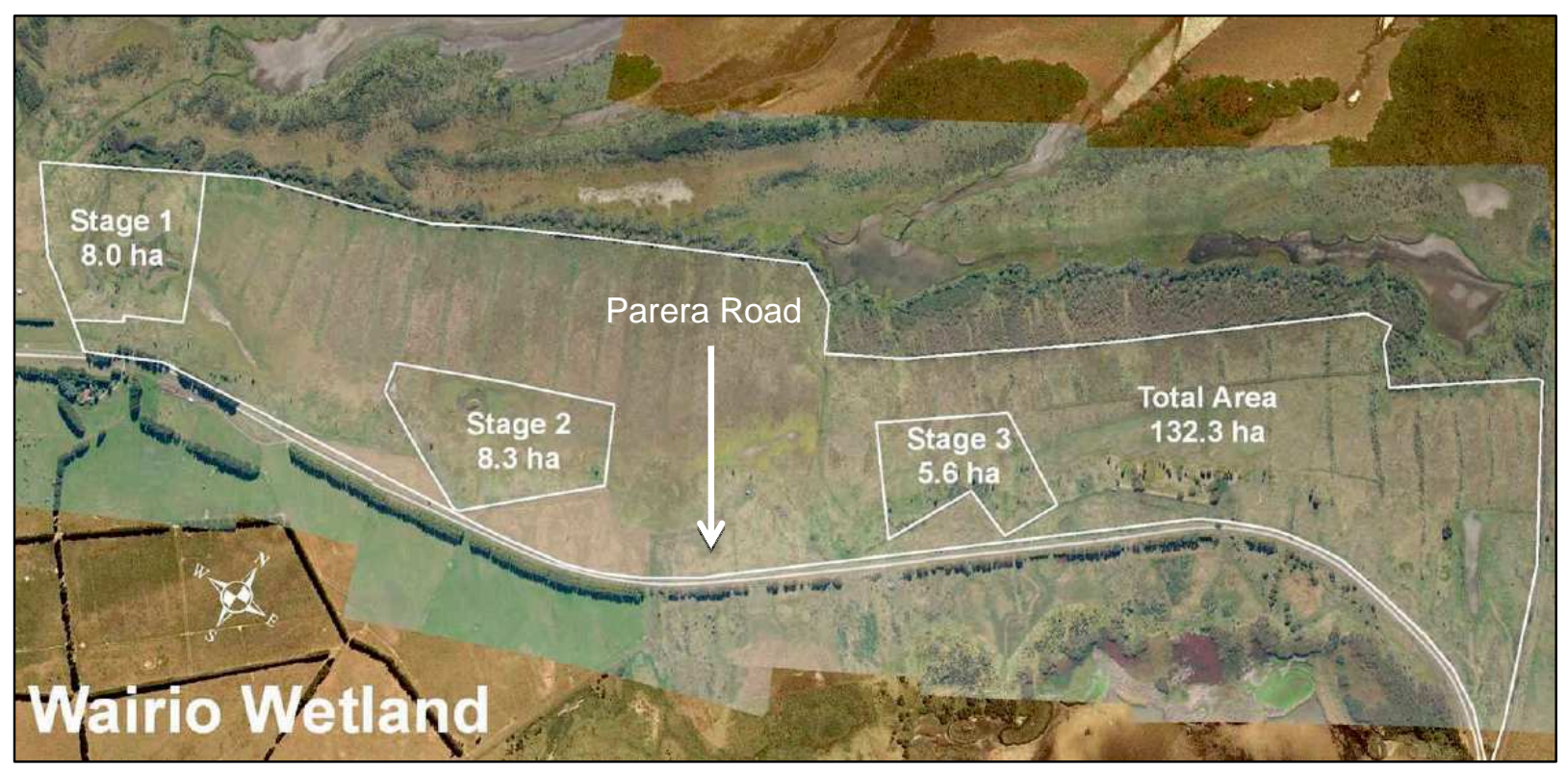

Figure 19 Aerial map of the Wairio wetland, showing the locations of Stages 1, 2, and 3.

\section{Study Species}

Planted native trees were categorised into two broad groups focal species are species characteristic of mature New Zealand swamp forest. They typically regenerate under a partial canopy and are relatively slow-growing; nurse trees are pioneers that 'grow fast and die young'; they are expected to cope better with competition from grasses and will provide shelter to help the establishment of slower-growing focal species (Smit et al., 2007). Focal species planted were totara (Podocarpus totara), kahikatea (Dacrycarpus dacrydioides), bush daisy (Olearia virgata) and cabbage tree (Cordyline australis). Nurse natives planted were kohuhu (Pittosporum tenuifolium), karamu (Coprosma robusta), mingimingi (Coprosma propinqua) and manuka (Leptospermum scoparium). The native tree species chosen were eco-sourced from Norfolk Road Nursery and Akura Conservation Centre in the Wairarapa. All species are known to be historically local to the Southern Wairarapa area (Enright et al., 2008).

Data about the trees planted comes from the New Zealand Conservation Network (2010). Totara is a slow growing canopy tree, growing up to $30 \mathrm{~m}$ tall. The leaves are long and narrow at both ends and are brownish green in colour. Green seeds growing atop of juicy red bases on female trees during autumn are highly attractive to birds. The totara is found in forests all around New Zealand and can tolerate wet, dry and windy conditions. 
The kahikatea is New Zealand's tallest forest tree and can grow up to $50 \mathrm{~m}$ high. It is dominant in lowland forests and wetlands throughout New Zealand. An adult tree has dark grey bark, with small scaly leaves which are 1-2 mm long. Their seeds are dispersed by birds attracted by the orange fleshy cones the tree produces.

The bush daisy is a fast growing shrub growing to $5 \mathrm{~m}$ high. It can tolerate high winds, although not overly damp soils. In spring it has an abundance of small white flowers. The cabbage tree can grow up to $20 \mathrm{~m}$ tall, it has a single grey trunk, which clusters in branches at the tip of the tree and has long narrow leaves that can grow to $1 \mathrm{~m}$ long. It produces strongly scented flowers which attract bees and later on berries which attract birds. They can tolerate exposed areas and wet soils.

The kohuhu is fast growing evergreen tree and popular to birds. It has black stems and shiny light green foliage, with dark red flowers in spring. It can grow up to $10 \mathrm{~m}$ high. It can tolerate a range of conditions, including shade, sun, exposed winds and most soils, provided they are well drained.

The karamu is a shrub which grows to be about $5 \mathrm{~m}$ high, with shiny green leathery leaves and brown bark. Birds are attracted by the small orange bitter fruits it produces. It is a tough fast growing plant that can grow in swampy soils or in a mountain forest. It can tolerate cold and windy conditions and is one of the most useful plants for controlling soil erosion.

Mingimingi is a small divaricating shrub that can hold many forms. It has small leaves and grows to between $3 \mathrm{~m}$ and $6 \mathrm{~m}$ tall. Females produce small blue fruit. It is a common swamp dweller that can tolerate a range of soil types and exposed areas.

The manuka or tea tree is an evergreen shrub that can grow to between $2 \mathrm{~m}$ and $15 \mathrm{~m}$ tall. It has small leaves ( $7 \mathrm{~mm}$ to $20 \mathrm{~mm}$ long) and small white flowers ( $8 \mathrm{~mm}$ to $15 \mathrm{~mm}$ in diameter). It is a very hardy plant that can tolerate most soil and exposed conditions. It is abundant in coastal areas, wetlands and low alpine habitats.

\section{Treatments}

Eleven different combinations of site preparation and after care treatments were applied to the site (Table 15). They come under five headings topsoil disturbance, weedmat, planting order, nurse species and nurse tree spacings. The treatments are topsoil excavated, topsoil retained, weedmat, no weedmat, concurrent planting of focal and nurse trees, advance planting of nurse trees, no nurse trees, nurse species combination 
1 (species Coprosma robusta and Coprosma propínqua), nurse species combination 2 (species Leptospermum scoparium and Pittosporum tenuifolium), nurse tree spacing of $1.5 \mathrm{~m}$ and nurse tree spacing of $0.75 \mathrm{~m}$. We wanted to test the overall usefulness of nurse natives, as well as the individual response of different species. The first three treatment techniques (Table 15) were applied in all possible combinations $(2 \times 2 \times 3=$ 12 ); when combined with two different mixtures of nurse species and two spacings in the 'advance planting', this resulted in 28 out of a possible 32 different treatment combinations being tested and replicated across 56 different plots (Table 16). Within each plot, half of the plants received weedmats and half did not. The weedmat zones occupied opposite quarters to minimise chance correlations with environmental gradients confounding the results.

Table 15 Five treatments with their corresponding options (treatment levels). The effects of planting order and nurse spacing were not analyses in this chapter.

\begin{tabular}{ll}
\hline Treatment Techniques & Options \\
\hline Topsoil & Topsoil excavated (0) \\
& Topsoil retained (1) \\
Weedmat or spot & No weedmat but with spot spraying follow up (0) \\
spraying of herbicide & Weedmat present, no follow up spot spraying (1) \\
& No nurse trees (focal trees only) (0) \\
Planting Order & Advance planting of nurse trees \\
& Concurrent planting of focal and nurse trees \\
& Coprosma robusta and Coprosma propínqua (1) \\
Nurse Species & Leptospermum scoparium and Pittosporum tenuifolium \\
& $(2)$ \\
Nurse Spacing & 1.5 -m spacing \\
& $0.75-m$ spacing \\
\hline
\end{tabular}

\section{Spatial Design}

Trees were planted in 56 plots (one plot is an array of 16 to 64 individual trees). Plots were grouped together into ten larger blocks scattered across Stage three of the Wairio wetland (Figure 20). Half of each block had topsoil excavated, with topsoil being retained on the other half. Eight of the blocks ( $30 \mathrm{~m}$ by $40 \mathrm{~m}, 288$ trees in each) contain three plots in each of their halves (representing the three nurse tree treatments concurrent planting vs. advance planting vs. no nurse trees): the remaining two blocks ( $30 \mathrm{~m}$ by 
$30 \mathrm{~m}, 160$ trees in each) contain two plots in each half (concurrent planting vs. no nurse trees). Each plot was divided into four quarters. Two quarters received weedmat and two quarters did not. The weedmat zones occupied opposite quarters to minimise chance correlations with environmental gradients confounding the result (Figure 21, Figure 22, Figure 23).

\section{Treatment Methods}

Preceding the treatments beginning, a herd of around 200 cows grazed Stage three in April 2011. Following this, the blocks were measured, staked and labelled. Dazzle spray paint was used to mark out where the native trees were to be planted.

\section{Topsoil Excavated}

On April $29^{\text {th }} 2011, \sim 10 \mathrm{~cm}$ of topsoil was excavated from half of each of the ten blocks; seven $15 \mathrm{~m}$ by $40 \mathrm{~m}$ blocks, two $15 \mathrm{~m}$ by $30 \mathrm{~m}$ blocks and one $30 \mathrm{~m}$ by $20 \mathrm{~m}$ block. The dirt was scraped to the end of each block forming low mounds where additional replanting of further wetland plants has since taken place (mostly flax, Phormium tenax).

\section{Topsoil Retained}

These areas are adjacent to the bulldozed scrapes and the same size. On May $31^{\text {st }} 2011$ a GWRC contractor sprayed (Buster, glufosinate-ammonium and Gardoprim, terbuthylazine) $1 \mathrm{~m}^{2}$ around each tree marking, apart from the natives planted at $0.75 \mathrm{~m}$, where the whole plot was sprayed.

\section{Native Nurse Trees: (i) Concurrent Planting 1.5-m Spacing - (20 Plots across 10 Blocks)}

The four native nurse species were paired to make two sets, 1 ( $C$. robusta and $C$. propinqua) and 2 (L. scoparium and $P$. tenuifolium). They were planted in a specific pattern inside the 10 blocks (Figure 21, Figure 22, Figure 23), at $1.5 \mathrm{~m}$ apart. These species are known to be fast growers and, therefore, can shade out weed species. The four focal species were planted concurrently in between these species. The idea of this treatment is to explore the concept of succession through the use of nurse tree species.

\section{Native Nurse Trees: (iia) Advanced Planting 1.5-m Spacing - (8 Plots across 4 Blocks)}

This treatment is similar to the above. Four native nurse species were paired 1 and 2 and planted $1.5 \mathrm{~m}$ apart in a specific pattern inside four blocks (Figure 21, Figure 22, Figure 23). The difference between this treatment and the above is that the focal species will not be planted in between them for another two or three years.

Native Nurse Trees: (iib) Advanced Planting 0.75-m Spacing - (8 Plots across 4 Blocks) 
This treatment is similar to (iia), with the only difference being that all the native species will be planted $0.75 \mathrm{~m}$ apart instead of the $1.5 \mathrm{~m}$ distance used for the rest of the species (Figure 21, Figure 22, Figure 23). This spacing will leave gaps for focal native species to be planted in between the native nurse trees in another two or three years' time.

\section{No Nurse Trees - (20 Plots Across 10 Blocks)}

These plots act as the control sites. Sixteen focal trees were planted in the same design as the other plots, but without any nurse trees. As with all other plots, two-quarters received weedmat and two-quarters did not.

Weedmats Present (Two-Quarters of Each and Every Plot (=58 Plots))

A commercial weedmat was cut into $60 \mathrm{~cm}$ by $60 \mathrm{~cm}$ squares, with a small central opening. Following planting, the weedmats were placed over the saplings on $25^{\text {th }}$ August 2011. They were secured by digging their corners into the soil. Only pre-planting weed spraying took place on these plots. If any weeds do eventually grow through, they can be hand weeded.

No Weedmats Present, Spot Spraying (Two-Quarters of Each and Every Plot (=58 Plots))

The first spot spraying around the young saplings took place on November $11^{\text {th }} 2011$, with another due in early 2012. This will be repeated twice (or as required) a year for two years (one spray in early 2012 already taken place). The spray was a mixture of Buster (glufosinate-ammonium) and Gardoprim (terbuthylazine). 


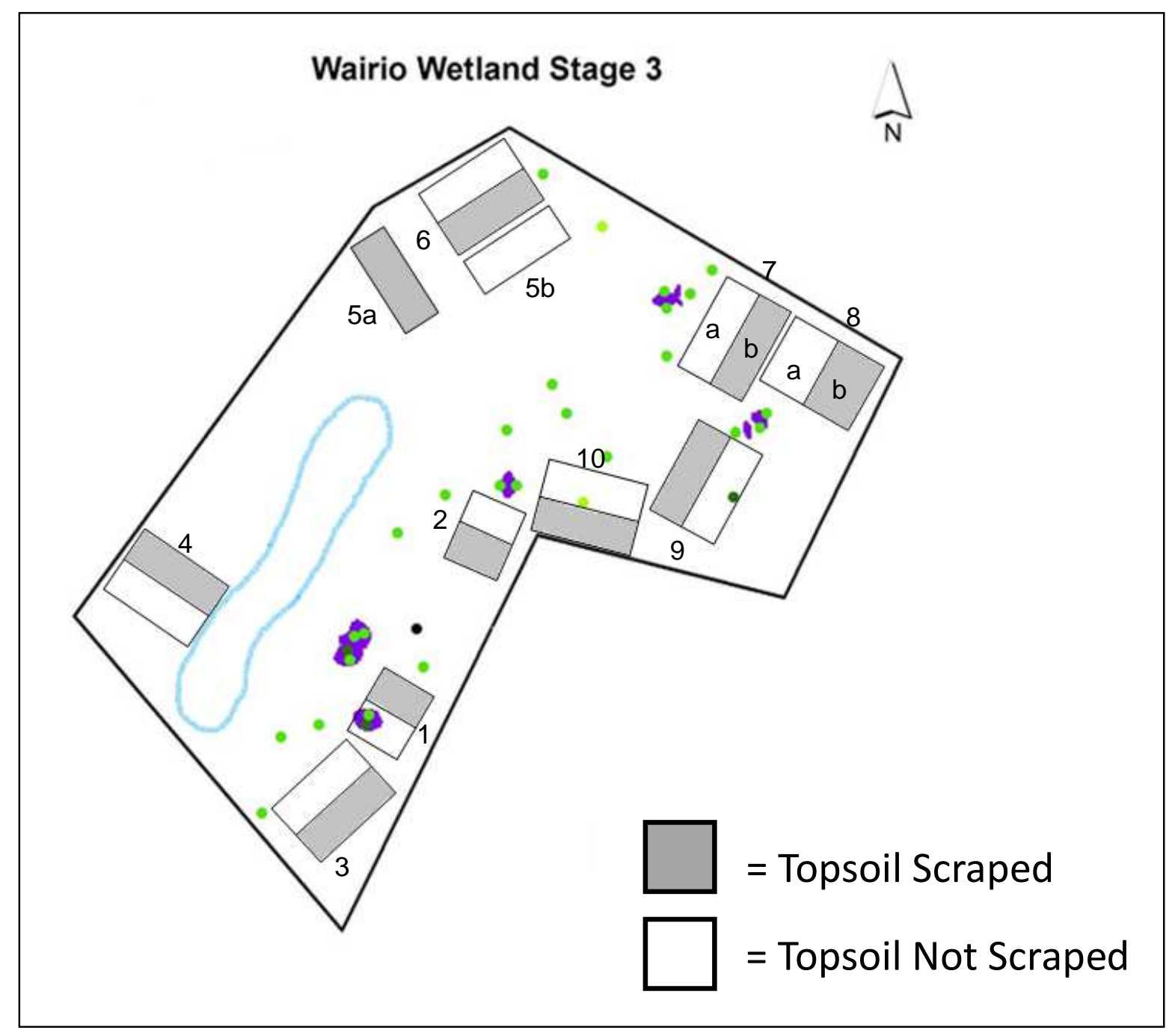

Figure 20 Map of Stage 3 at Wairio wetland,, with the pond (outlined in blue) and the ten blocks. Green and black dots represent existing trees, purple indicates cluster of trees. 


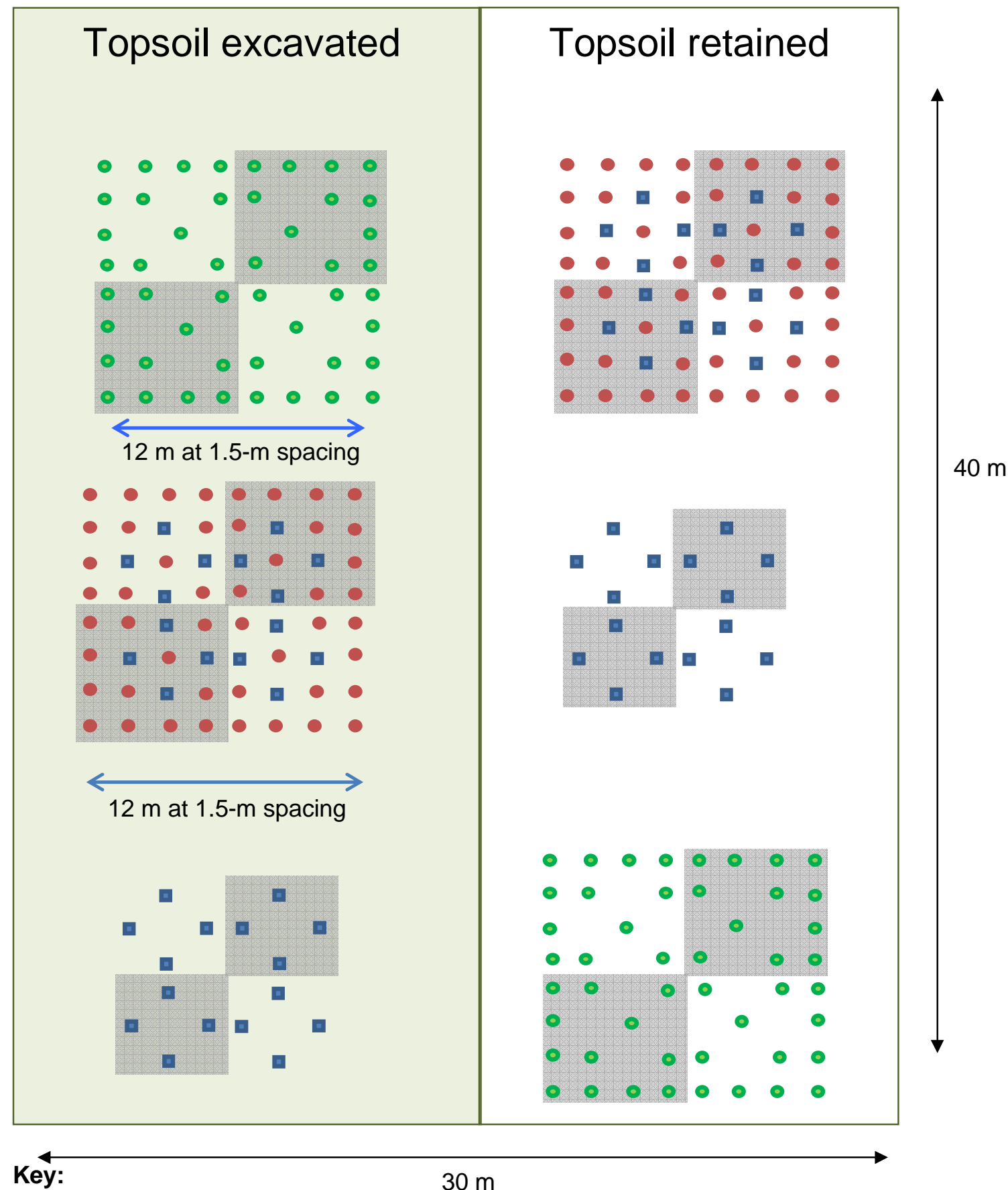

- Advance Planting of nurse trees $1.5 \mathrm{~m}$ trees

Focal species 1-4

Figure 21 There are four replicates of the above large blocks (30 $\mathrm{m}$ by $40 \mathrm{~m})$. This will use 96 focal natives, 192 native nurse trees in each block (288 in total). Blocks with this configuration are labelled $3,5,7 a$, $8 a$ and 9 in Figure 20. Not to scale.

Weedmats 


\section{Topsoil excavated}
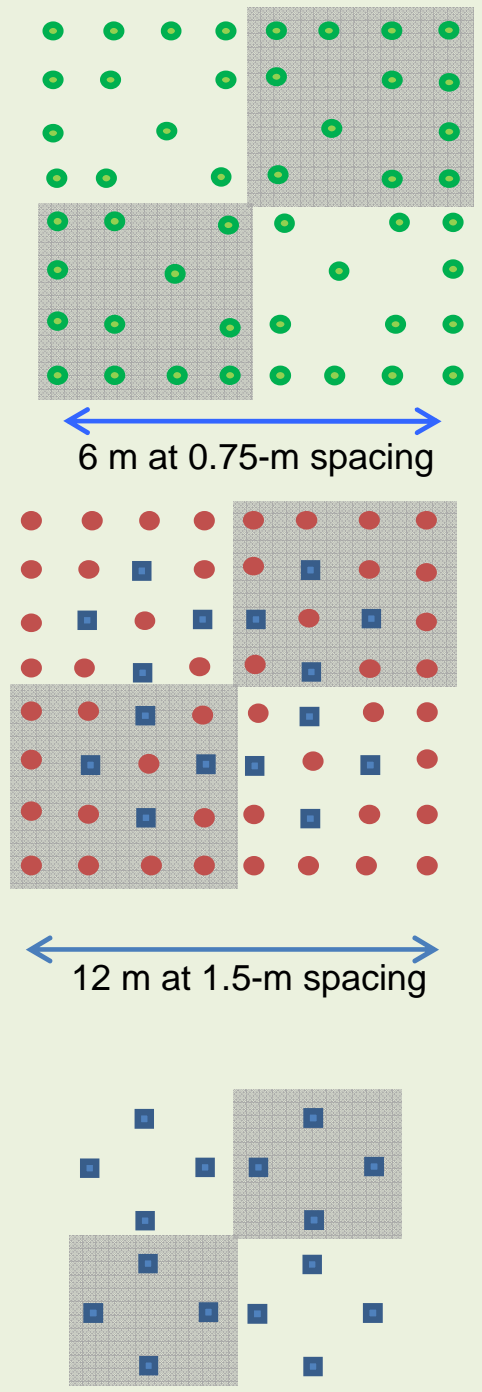

\section{Topsoil retained}
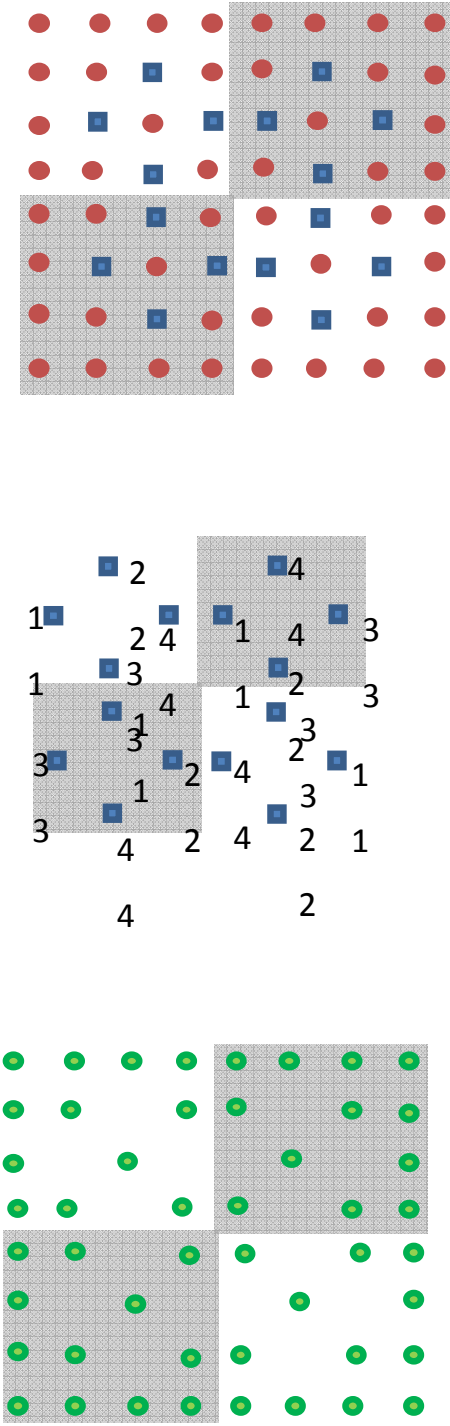

\section{Key:}

$30 \mathrm{~m}$

- Advance planting of nurse trees 0.75

Concurrent planting of nurse \& focal

Focal species 1-4

Figure 22 There are four replicates of the above large blocks (30 m by $40 \mathrm{~m}$ ). This will use 96 focal natives, 192 native nurse trees in each block (288 in total). Blocks with this configuration are labelled $4,6,7 b, 8 b$ and 10 in Figure 20 . Not to scale.

Weedmats 


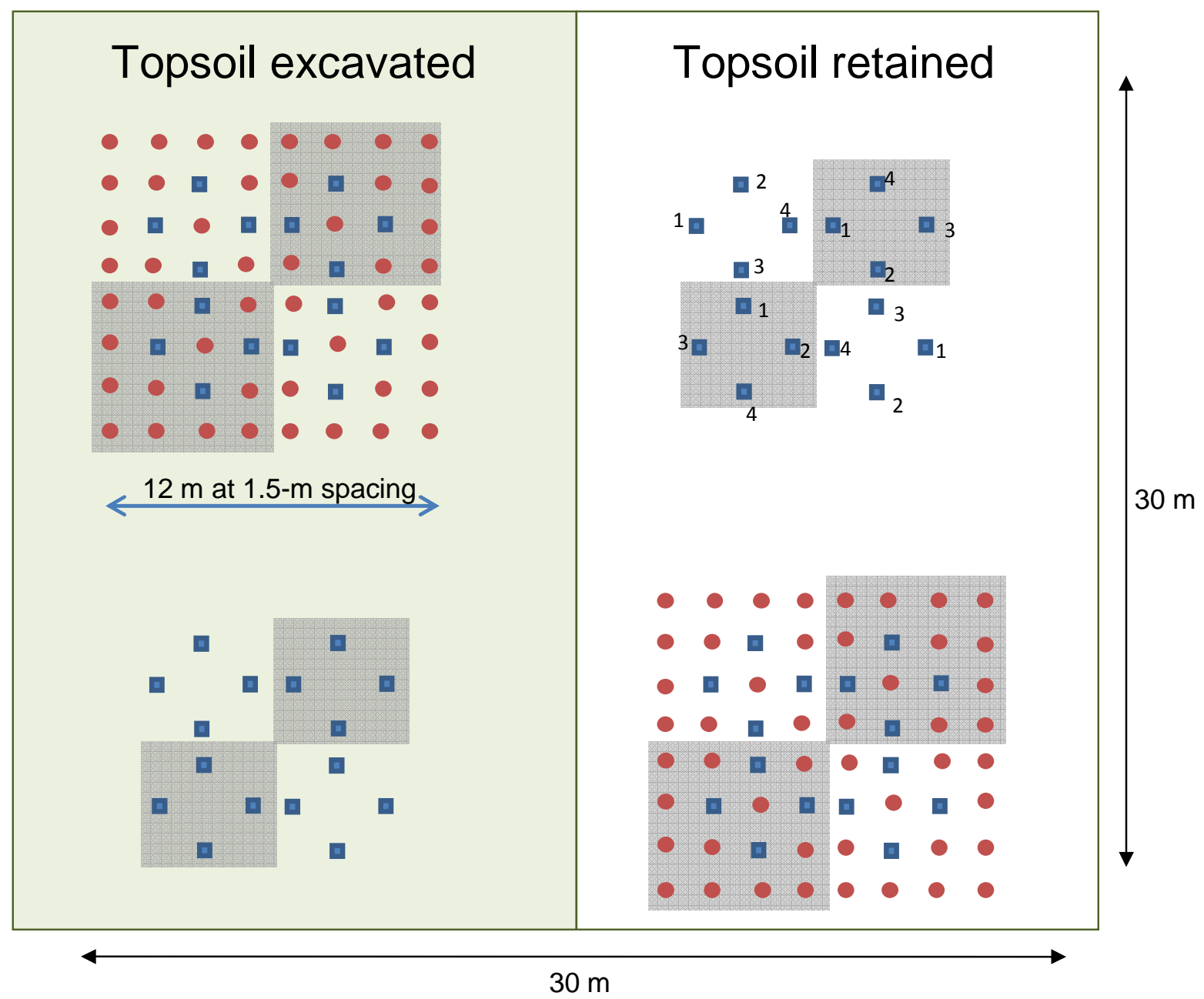

Key:

- Native nurse tree 1-4

Focal species 1-4

Weedmats
Figure 23 Times two replicates of the above medium blocks ( $30 \mathrm{~m}$ by $30 \mathrm{~m}$ ). This will use 64 focal natives and 96 native nurse trees in each block (160 in total). These blocks are labelled 1-2 in Figure 20. Not to scale. 
Table 16 Block numbers with corresponding treatments and nurse tree species.

\begin{tabular}{|c|c|c|c|c|}
\hline Block \# & Plot 1 Treatment & Plot 2 Treatment & Plot 3 Treatment & Nurse species combination \\
\hline 1 & No nurse natives & Concurrent planting & na & C. robusta and C. propinqua \\
\hline 2 & No nurse natives & Concurrent planting & na & P. tenuifolium and L. scoparium \\
\hline 3 & No nurse natives & Concurrent planting & Advance planting, 1.5-m spacing & P. tenuifolium and L. scoparium \\
\hline 4 & No nurse natives & Concurrent planting & Advance planting, 0.75-m spacing & C. robusta and C. propinqua \\
\hline 5 & No nurse natives & Concurrent planting & Advance planting, 1.5-m spacing & C. robusta and C. propinqua \\
\hline 6 & No nurse natives & Concurrent planting & Advance planting, 0.75-m spacing & P. tenuifolium and L. scoparium \\
\hline $7 a$ & No nurse natives & Concurrent planting & Advance planting, $1.5-\mathrm{m}$ spacing & P. tenuifolium and L. scoparium \\
\hline $7 b$ & No nurse natives & Concurrent planting & Advance planting, 0.75-m spacing & P. tenuifolium and L. scoparium \\
\hline $8 a$ & No nurse natives & Concurrent planting & Advance planting, $1.5-\mathrm{m}$ spacing & C. robusta and C. propinqua \\
\hline $8 b$ & No nurse natives & Concurrent planting & Advance planting, 0.75-m spacing & C. robusta and C. propinqua \\
\hline 9 & No nurse natives & Concurrent planting & Advance planting, $1.5-\mathrm{m}$ spacing & C. robusta and C. propinqua \\
\hline 10 & No nurse natives & Concurrent planting & Advance planting, 0.75-m spacing & P. tenuifolium and L. scoparium \\
\hline
\end{tabular}




\section{Trees}

In 2011, a total of 2,368 trees were required (Table 17). These were planted between June $23^{\text {rd }} 2011$ and July $4^{\text {th }} 2011$, with the help of 30 volunteers. All volunteers were briefed on the correct planting technique, so consistency was ensured.

Table 172011 native tree requirements.

\begin{tabular}{|c|c|c|c|c|}
\hline Medium blocks & $\begin{array}{c}\text { Total number of trees } \\
\text { per block }\end{array}$ & \# of blocks & \# of trees & \\
\hline Focal native & 64 & 2 & 128 & \\
\hline Native nurse & 96 & 2 & 192 & \\
\hline Subtotal & 160 & - & 320 & \\
\hline \multicolumn{5}{|l|}{ Large blocks } \\
\hline Focal native & 64 & 8 & 512 & \\
\hline Native nurse & 192 & 8 & 1536 & \\
\hline Subtotal & 288 & - & 2048 & \\
\hline Combined blocks & & & & Per species \\
\hline Focal native & - & 10 & 640 & 160 \\
\hline Native nurse & - & 10 & 1728 & 432 \\
\hline Grand total & - & - & 2368 & \\
\hline
\end{tabular}

\section{Monitoring}

All native focal trees (160 of each species) were individually labelled with aluminium tags (Forestry tools, Alutags) and measured in early July 2011. The species were given code names according to their scientific names ( $\mathrm{Pt}, \mathrm{Dd}, \mathrm{Ca}, \mathrm{Ov}$ ) and numbered 1 to 160 . The numbering starts at block one and continues to block 10. Each zone has four focal species (one of each species), so each of the four trees have the same number, but different species codes. Measurements made were height of the tree, using a common ruler; percentage of above-ground water present within $1 \mathrm{~m}^{2}$; average depth of the water, using the same ruler; and percent plant cover within $1 \mathrm{~m}^{2}$. Measurements were repeated at the beginning of the desiccation period between December $17^{\text {th }}$ and $22^{\text {nd }} 2011$. Tree survival was also recorded in December. Survival of each focal tree was recorded and a 
percentage survival rate for each plot was obtained. Herbivory data were measured as three categories, 0 for none, 1 for total plant herbivory and 0.5 for some herbivory obvious on the plant.

\section{Cost-Benefit Analysis of Survival}

A conceptual framework was used to assess the economic suitability of the restoration techniques, called a cost-benefit analysis (CBA, Equation 1) (Angelsen and Sumaila, 1995). Graphical outputs were produced in Microsoft Excel (Microsoft Corporation, 2010). Cost of the management treatments was evaluated and analysed per focal tree. The percentage survival of each treatment combination and focal species were calculated. The cost-benefit analysis was calculated by

Equation 1 Cost-benefit analysis.

$$
\text { CBA }=\frac{\text { Total } \cdot \text { Cost } \cdot \text { of } \cdot \text { Treatment }}{\text { Survival } \cdot \text { of } \cdot \text { Species }} \times \frac{100}{1}=\text { Cost } \cdot \text { per } \cdot \text { surviving } \cdot \text { tree }
$$

Survival and height of a subsample of nurse trees was recorded at the four corner trees in each plot, along with the abiotic factors of percent plant cover and water ( $n=432$ per species).

\section{Analysis of Experimental Treatments, Effects on Growth Rates}

Relative growth of each focal species was analysed using linear mixed effects models. Fixed effects included in the model were topsoil (two levels, split across each block), weedmat or spray (two levels split across plots), presence and species of nurse trees (three levels, differing from one plot to another), percent plant cover in December 2011, percentage water (covariates measured at the individual plant) and all two-way interactions between these effects (see Table 15 and Figs 20-23 for further details of the design). The effect of advance planting vs. concurrent planting of nurse trees was not included in the model as there were no focal trees yet present in the advance planting. Random effects were included for the 'block' and 'plot nested within block'. Throughout the paper, we present the estimated p-values, which are considered significant at the $p$ value $\leq 0.05$ level. $\log _{10}$ transformations were used on the growth of the focal tree species, hence a value of 0 indicates no change in height and a value of 1 indicates tenfold growth. Due to the comparatively higher survival rates of the native trees, relative growth was used instead of tree survival. No survival results were collected from block four, as this site was inundated with water, so final measurements could not be taken. 
Data were analysed using the $\mathrm{R}$ computer programme (2.14.1) (R Development Core Team, 2011) and the 'Ime' command of the R package 'nlme' (Pinheiro et al., 2012).

\section{Results}

\section{Cost-Benefit Analysis of Survival}

The combined cost of the management techniques used and trees planted at the Wairio wetland came to a total of $\$ 9,804$ (Figure 24, prices stated in New Zealand dollars, break down of costs in Appendix 3.1). The most significant cost was purchasing the native trees; the 864 Coprosma nurse species were the most expensive $(\$ 2,203)$, followed by the purchase of the 640 focal trees $(\$ 1,494)$ and, thirdly, the 864 L. scoparium and $P$. tenuifolium nurse tree combination $(\$ 1,296)$. The addition of weedmats adds $\$ 2,572$; current spot and release spraying costs are $\$ 686$; however, this does not include the subsequent release spraying that will occur bi-annually for two to three years (estimated at $\$ 686$ per year). The cost of the volunteer hours was due to a BBQ on the planting day. As a comparison, hypothetical labour costs were included into the analysis at $\$ 13.00$ /hour (New Zealand minimum wage; Department of Labour, 2011), over the 390 hours logged, giving an estimate of labour costs at $\$ 5,070$; a total of $\$ 14,874$ with the management technique costs included (Figure 25). The cost of planning and monitoring the planting as an experiment has not been included in the analysis. 


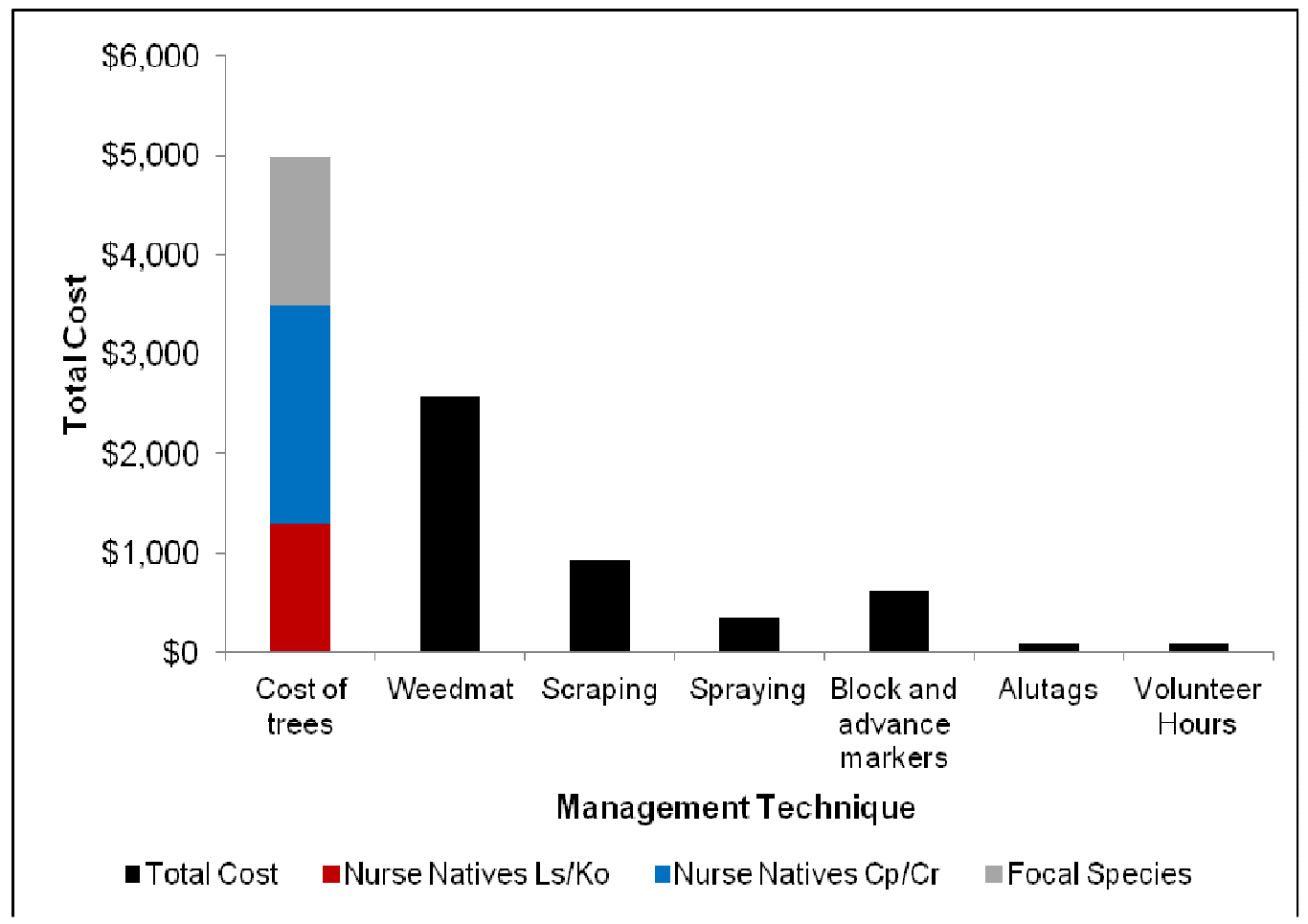

Figure 24 Total cost of each management technique. 


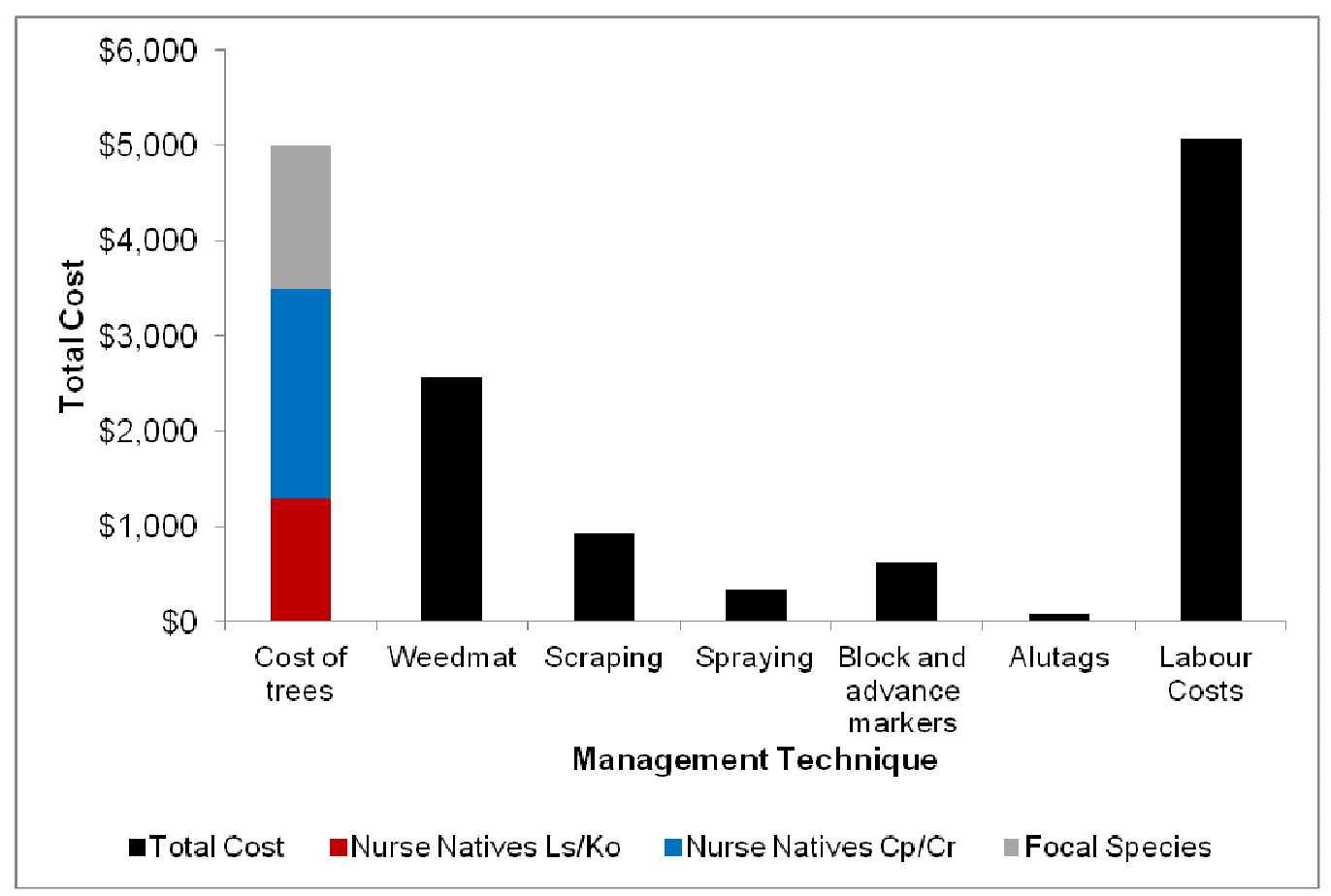

Figure 26 Total cost of each management technique, including hypothetical cost of actual labour hours spent on restoration at Wairio wetland during 2011.

Total costs were combined as management technique costs per focal tree planted. Figure 26 shows the categorisation of the method combinations. The most expensive combination of management techniques is scraped topsoil plus Coprosma nurse trees and weedmats (\$22.82 per focal tree). Subtracting nurse trees from the combination significantly lowers the cost per focal tree by $\$ 12.99$ for Coprosma nurse trees and $\$ 5.76$ for the $L$. scoparium and $P$. tenuifolium nurse tree combination. The use of a weedmat with nurse trees adds $\$ 3.92$ per focal tree and without nurse trees adds $\$ 0.98$. The cheapest management technique option is spot spraying with no nurse tree ( $\$ 2.39$ per focal tree). In the planting design used for the nurse tree plots, 2.7 nurse trees were planted for every focal tree. The extra corner trees were added for ease of planting and creating square $8 \times 8$ tree plots; this does add an extra 4 'additional' focal trees into the mix, which could be omitted in a restoration setting. 


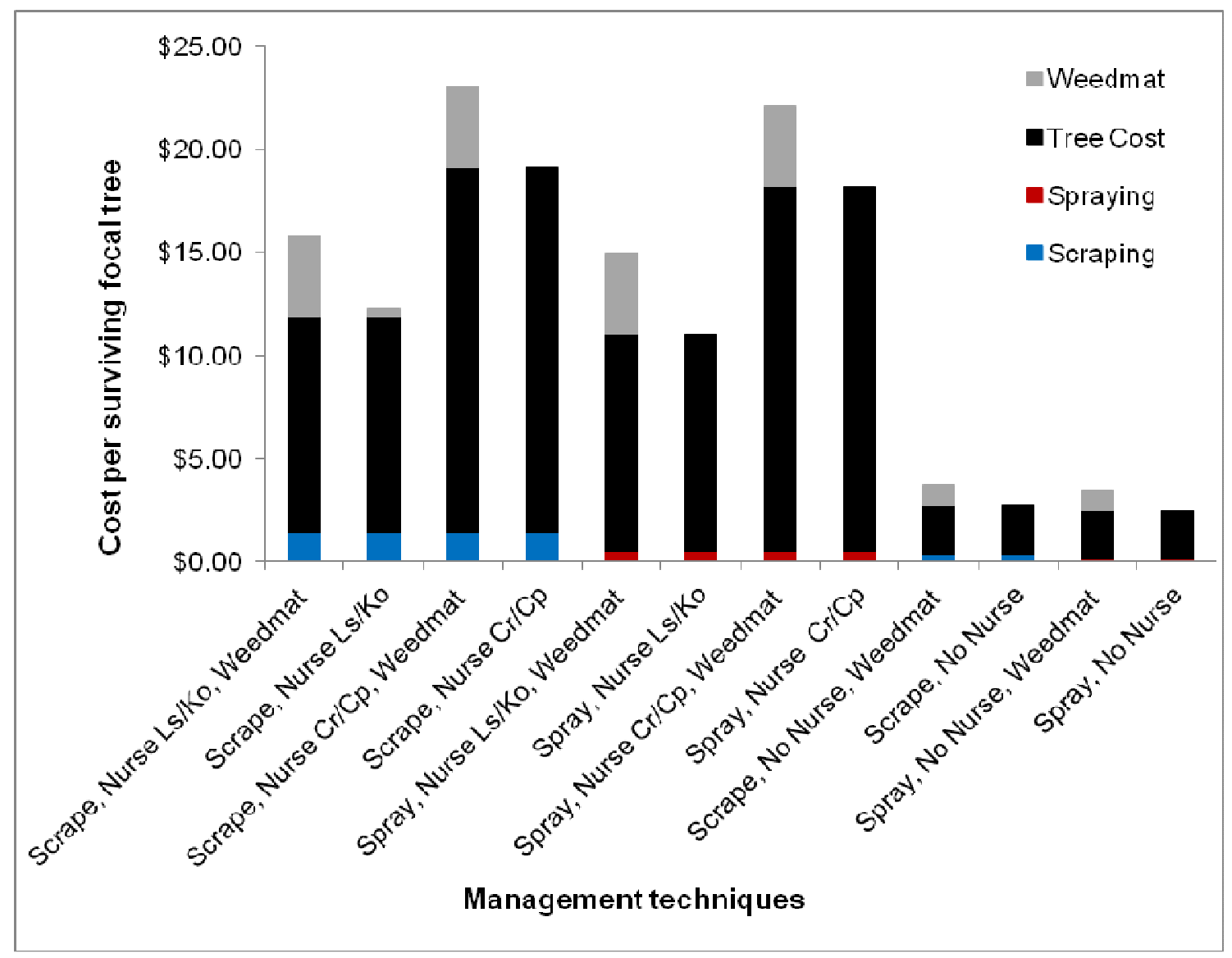

Figure 27 Total cost of management techniques combined per focal tree.

The average survival rates of each species across all treatments were most successful D. dacrydioides at $97.87 \%$, O. virgata at $93.17 \%, P$. totara at $91.30 \%$ and least successful C. australis at $87.20 \%$ (Table 18). The average survival rate of all focal species was $92.38 \%$. The lowest survival rate was $62.50 \%$ for $P$. totara with the management technique of scraped plus Coprosma spp. nurse trees and weedmats. The most successful management techniques had $100 \%$ focal species survival. These were scraped with $L$. scoparium and $P$. tenuifolium nurse trees, with and without weedmats. The least successful management techniques had $87.5 \%$ focal species survival, these were scraped areas with Coprosma nurse trees, with and without weedmats. 
Table 18 Percent survival rate of focal species planted across the varying management treatment over the first 6 months of growth. Dark shading indicates lower survival rates $(<90 \%)$.

\begin{tabular}{lccccc}
\hline Management technique & D. dacrydioides & C. australis & O. virgata & P. totara & Average survival by treatment \\
\hline & & & & & \\
Scraped, Nurse Ls/Ko, Weedmat & 100 & 100 & 100 & 100 & 100 \\
Scraped, Nurse Ls/Ko & 100 & 100 & 100 & 100 & 100 \\
Scraped, Nurse Cr/Cp, Weedmat & 100 & 87.5 & 100 & 62.5 & 87.5 \\
Scraped, Nurse Cr/Cp & 100 & 75.0 & 87.5 & 87.5 & 87.5 \\
Scraped, No Nurse, Weedmat & 100 & 83.3 & 94.4 & 77.8 & 88.9 \\
Scraped, No Nurse & 100 & 83.3 & 83.3 & 88.9 & 88.5 \\
Unscraped, Nurse Ls/Ko, Weedmat & 100 & 90 & 100 & 90 & 95 \\
Unscraped, Nurse Ls/Ko & 80 & 80 & 100 & 100 & 90 \\
Unscraped, Nurse Cr/Cp, Weedmat & 100 & 87.5 & 87.5 & 100 & 93.8 \\
Unscraped, Nurse Cr/Cp & 100 & 87.5 & 87.5 & 100 & 93.8 \\
Unscraped, No Nurse, Weedmat & 100 & 83.3 & 83.3 & 100 & 91.7 \\
Unscraped, No Nurse & 94.4 & 88.9 & 94.4 & 88.9 & 91.7 \\
Average success rate of species & 97.9 & 87.2 & 93.2 & 91.3 & \\
& & & & & \\
\hline
\end{tabular}


Table 19 presents the survival rates of the nurse native trees. The main surviving species were Leptospermum scoparium both with and without weedmats and Pittosporum tenuifolium, without weedmats.

Table 19 Survival of nurse trees.

\begin{tabular}{lrrr}
\hline \multirow{2}{*}{ Species } & \multicolumn{3}{c}{ Percentage survival (\%) } \\
\cline { 2 - 4 } & Weedmat & No weedmat & Average \\
\cline { 2 - 4 } Coprosma propinqua & NA & 91.66 & 91.66 \\
Coprosma robusta & 75.00 & NA & 75.00 \\
Leptospermum scoparium & 100.00 & 100.00 & 100.00 \\
Pittosporum tenuifolium & 75.00 & 100.00 & 87.50 \\
\hline
\end{tabular}

Table 20 and Figure 27 present the cost-benefit analysis of the focal species and the corresponding management treatments; it is expressed as the cost of treatments to get one focal tree to survive six months, including the cost of any associated nurse trees. The most cost-effective treatment combination is $C$. australis subjected to unscraped topsoil with no nurse trees; the cost per surviving tree is $\$ 1.93$. The least cost-effective combination is $P$. totara with scraped topsoil Coprosma nurse trees and weedmats; the cost per surviving tree is $\$ 36.50$. Dacrycarpus dacrydioides was the most cost-effective focal species, with an average cost of $\$ 12.56$ per surviving tree; the least cost-effective species were $O$. virgata and $P$. totara, with an average cost of $\$ 14.23$ per surviving tree. The most beneficial treatment combination was unscraped topsoil with no nurse tree or weedmat, with an average cost of $\$ 2.77$ per surviving tree; the least beneficial treatment combination is scraped, with Coprosma nurse trees and weedmats, with an average cost of $\$ 27.19$ per surviving focal tree. 
Table 20 Cost-benefit analysis (cost per surviving tree) of each focal tree species per management treatment combination in the first six months of growth.

\begin{tabular}{lcccc}
\hline Management technique & $\begin{array}{c}\text { D. dacrydioides } \\
\mathbf{( \$ )}\end{array}$ & $\begin{array}{c}\text { C. australis } \\
\mathbf{( \$ )}\end{array}$ & $\begin{array}{c}\text { O. virgata } \\
\mathbf{( \$ )}\end{array}$ & $\begin{array}{c}\boldsymbol{P} \text {. totara } \\
\mathbf{( \$ )}\end{array}$ \\
\hline Scraped, Nurse Ls/Ko, Weedmat & 15.62 & 14.95 & 16.95 & 15.62 \\
Scraped, Nurse Ls/Ko & 11.70 & 11.03 & 13.03 & 11.70 \\
Scraped, Nurse Cr/Cp, Weedmat & 22.82 & 25.31 & 24.15 & 36.50 \\
Scraped, Nurse Cr/Cp & 18.90 & 24.30 & 23.11 & 21.59 \\
Scraped, No nurse, Weedmat & 14.71 & 16.85 & 16.99 & 18.92 \\
Scraped, No nurse & 10.79 & 12.15 & 14.55 & 12.14 \\
Unscraped, Nurse Ls/Ko, Weedmat & 21.91 & 23.60 & 23.24 & 24.35 \\
Unscraped, Nurse Ls/Ko & 22.49 & 21.65 & 19.32 & 17.99 \\
Unscraped, Nurse Cr/Cp, Weedmat & 3.51 & 3.24 & 5.53 & 3.51 \\
Unscraped, Nurse Cr/Cp & 2.53 & 2.12 & 4.41 & 2.53 \\
Unscraped, No nurse, Weedmat & 3.28 & 3.13 & 5.53 & 3.28 \\
Unscraped, No nurse & 2.53 & 1.93 & 3.94 & 2.69 \\
\hline
\end{tabular}

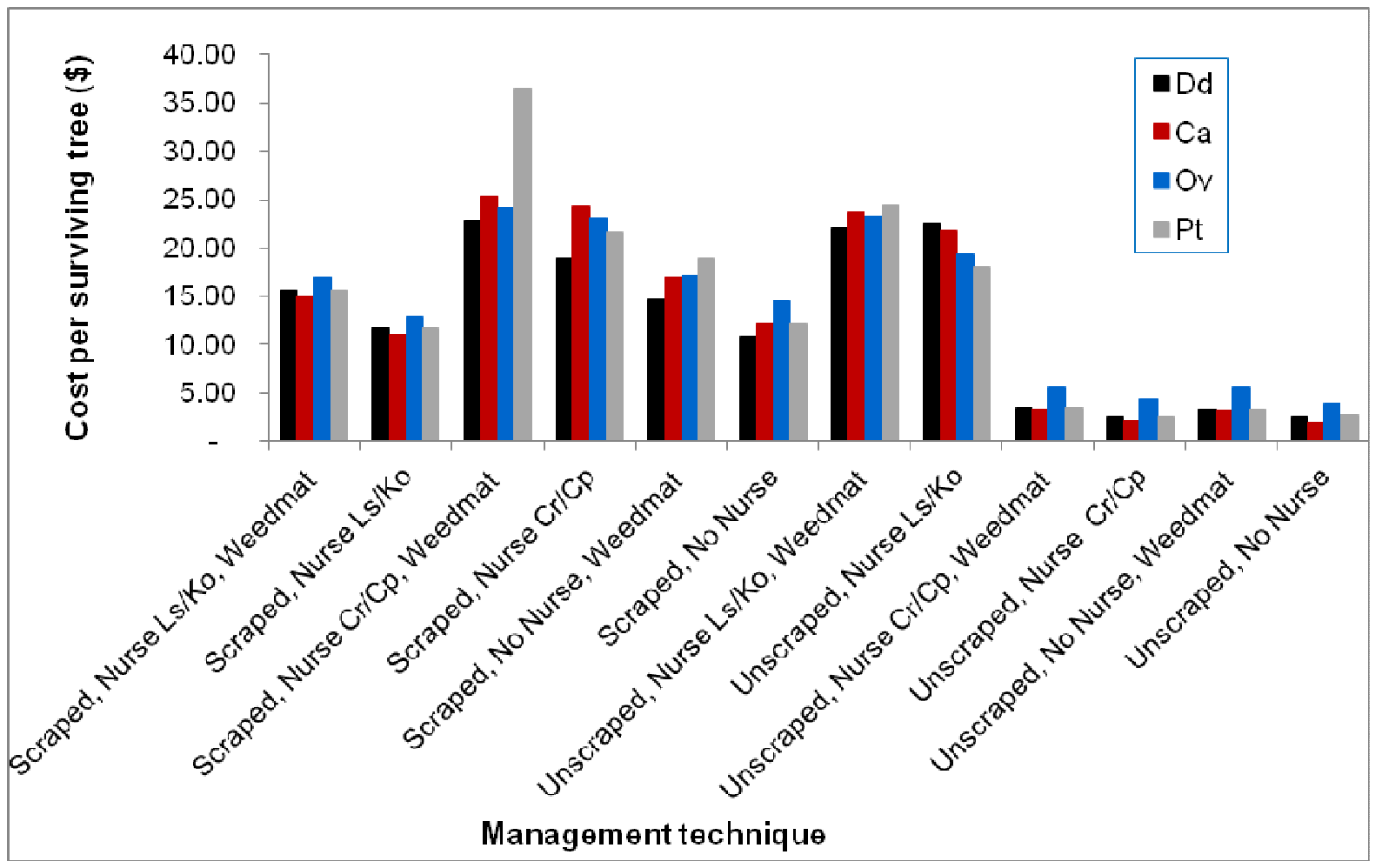

Figure 28 Cost-benefit analysis (cost per surviving focal tree) of each focal tree species per management technique. 


\section{Experimental Treatments, Effects on Growth Rates}

Results on the survival of focal trees showed that $O$. virgata and $P$. totara are more likely to die as a result of high percent cover of water. No other treatments were significant for these species or any others (Table 21). The survival rate of the four focal trees in relation to percentage water cover is shown in Figure 28. Species $D$. dacrydioides did not converge due to high survival rates, so has been left out of Table 21 .

Table 21 Logistical regression of focal species survival in regard to management treatment options. $\left({ }^{*}\right.$ indicate sig. p-value, ${ }^{*}<0.05,{ }^{* *}<0.01,{ }^{* \star *}<0.001$, NS indicates no significant effect).

\begin{tabular}{lrrrrrr}
\hline \multirow{2}{*}{ Management Treatments } & \multicolumn{2}{c}{ C. australis } & \multicolumn{2}{c}{ O. virgata } & \multicolumn{2}{c}{ P. totara } \\
\cline { 2 - 7 } & Beta Coeff. & P-value & Beta Coeff. & P-value & Beta Coeff. & P-value \\
\hline Topsoil & 0.253 & 0.8549 & -2.605 & 0.1060 & -0.246 & 0.8035 \\
Nurse1 & 16.987 & 0.9956 & -1.538 & 0.3100 & -1.189 & 0.2821 \\
Nurse2 & 0.175 & 0.8930 & 2.819 & 0.0930 & 0.393 & 0.7565 \\
Weedmat1 & -0.985 & 0.4430 & -2.218 & 0.0887 & -1.710 & 0.1373 \\
\% plant cover in December & -0.036 & 0.1307 & 0.041 & 0.2208 & 0.003 & 0.8712 \\
\% water cover (average) & -0.022 & 0.4860 & -0.091 & $0.0037^{* *}$ & -0.035 & $0.0061^{* *}$ \\
\hline
\end{tabular}



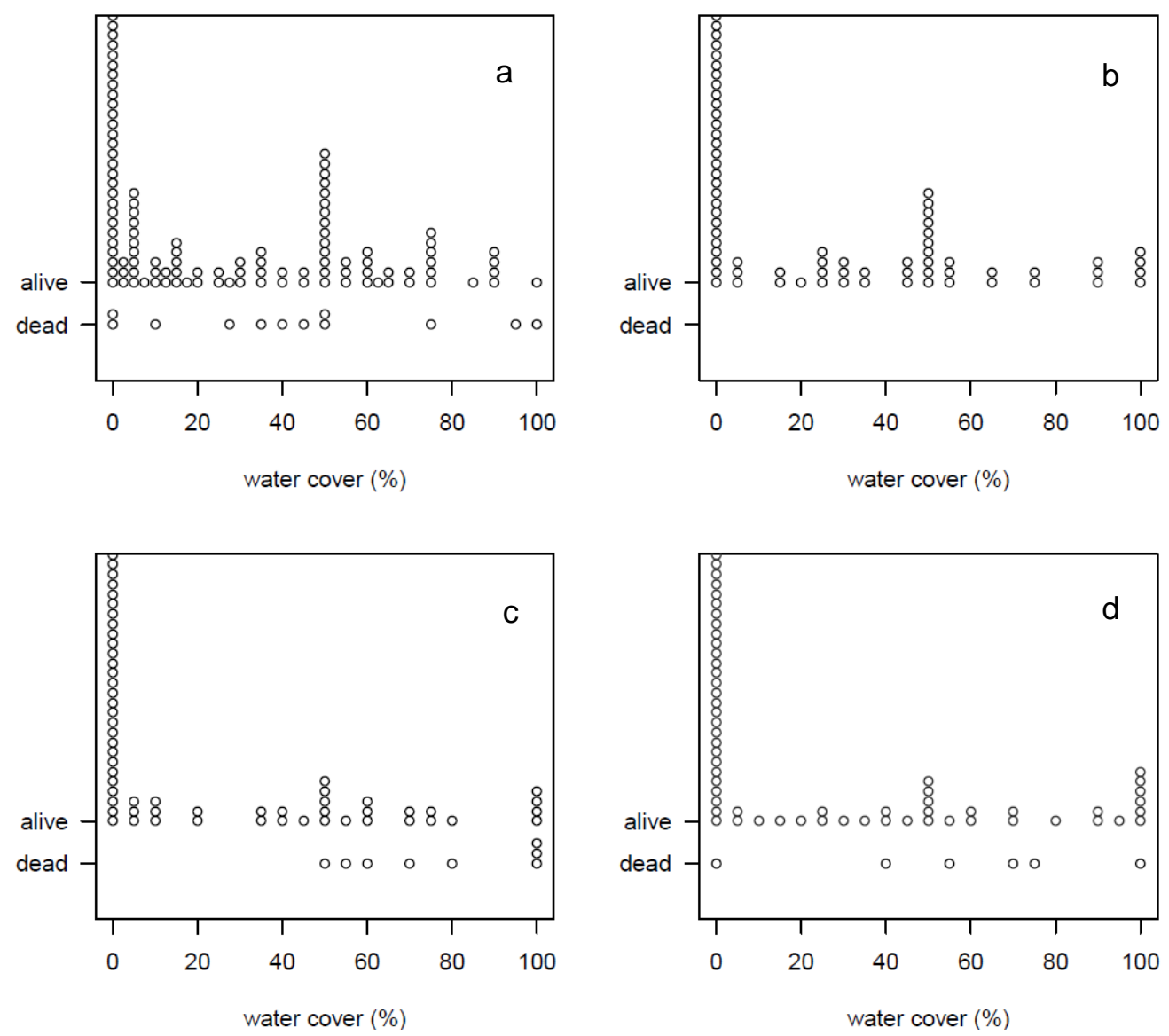

Figure 29 Focal tree survival in relation to average percentage water cover A) C. australis showing the most dead trees, B) D. dacrydioides which had no dead trees, C) 0 . virgata, D) $P$. totara. The number of live trees at water cover $(\%)=0$ has been truncated due to the limits of the $y$-axis.

The height increment of focal species varied over their first six-month development at Wairio wetland (Figure 29). Cordyline australis had the greatest variation in relative growth and the highest average growth. Species $D$. dacrydioides has the least variation of growth rate and the lowest average growth. Olearia virgata and $P$. totara have similar spread and average height increments of just over $\mathrm{x} 1$. 


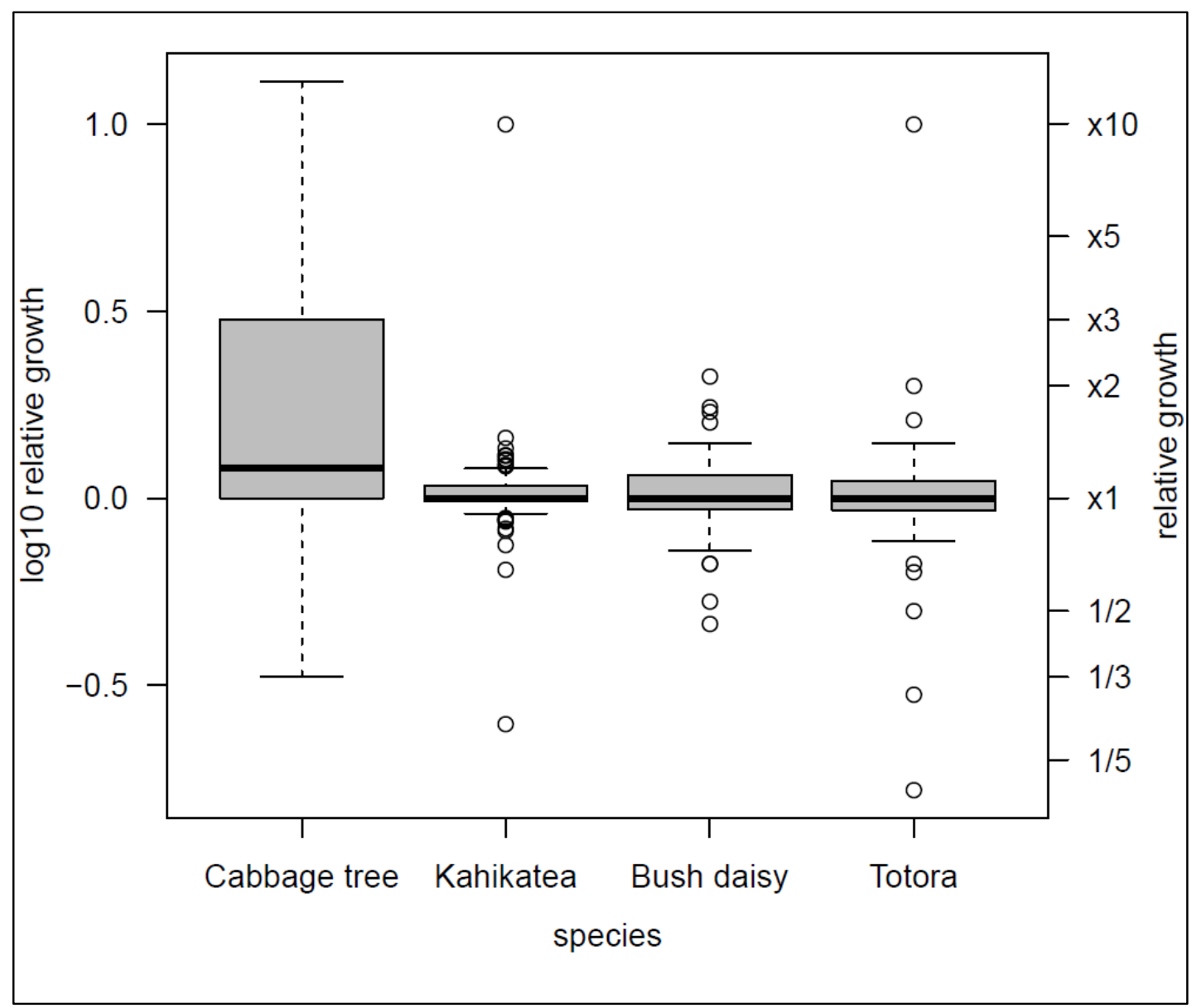

Figure 30 Boxplots of growth (height increment) of the four focal species in the first six months after planting. Dark lines represent medians, boxes indicate the interquartile range (central $50 \%$ of observations), and whiskers represent the trimmed range with dots representing outliers. 
Using a linear mixed-effects model, it was found that four management treatments had a significant effect on relative growth of two of the four focal species during their first six months of development at the Wairio wetland (Table 22). An interaction between topsoilscraping and percentage water present (t-value $=-3.863$, d.f $=76, p$-value $=0.0002$ ) (Figure 30) and an interaction between percentage cover of plants in December 2011 and percentage water present ( $t$-value $=2.061$, d. $f=76$, $p$-value $=0.0425$ ) significantly affected the relative growth of $O$. virgata. Significantly higher growth rates of $O$. virgata were associated with wet sites with topsoil scraped; and the high growth rate of $O$. virgata was associated with dry sites combined with more plant cover. The relative growth of $C$. australis was significantly affected by the interaction of nurse tree species L. scoparium and P. tenuifolium and percentage cover of plants in December 2011 (tvalue $=2.075, \mathrm{~d} . \mathrm{f}=72, \mathrm{p}$-value $=0.0416)($ Figure 31$)$ and the single treatment topsoil ( $\mathrm{t}$ value $=2.107$, d. $f=72, p$-value $=0.0468$ ). This indicates $C$. australis has high growth rates when associated with a combination of nurse trees $L$. scoparium and $P$. tenuifolium and more cover of plants and $C$. australis has high growth with topsoil intact. No other treatments had significant effects on the focal species growth. For all species the majority of raw variation was between individuals, with little variation due to the particular plots $(<4 \%)$ or blocks $(<20 \%)$. 
Table 22 P-values for the linear fixed-effects model for height increment across all four focal species fit by maximum likelihood. ( ${ }^{*}$ indicate sig. $p$-value, * $<0.05$, ${ }^{* *}<0.01,{ }^{* *}<0.0001$. NS indicates $p$-values $>0.1$ ). Each level of each factor is being tested against the baseline effect or level 0 option (Table 15 ).

\begin{tabular}{|c|c|c|c|c|c|c|c|c|c|c|c|c|}
\hline \multirow[b]{2}{*}{ Linear fixed-effects } & \multicolumn{3}{|c|}{ D. dacrydioides } & \multicolumn{3}{|c|}{ C. australis } & \multicolumn{3}{|c|}{ O. virgata } & \multicolumn{3}{|c|}{ P. totara } \\
\hline & Beta coeff. & d.f & $p$-values & Beta coeff. & d.f & $p$-values & Beta coeff. & d.f & $p$-values & Beta coeff. & d.f & $p$-values \\
\hline Topsoil & & 88 & NS & 0.329 & 72 & $0.047^{*}$ & & 76 & NS & & 79 & NS \\
\hline Nurse (Ls/Ko) & & 22 & NS & & 22 & NS & & 21 & NS & & 21 & NS \\
\hline Nurse (Cr/Cp) & & 22 & NS & & 22 & NS & & 21 & NS & & 21 & NS \\
\hline Weedmat & & 22 & NS & -0.229 & 22 & 0.065 & & 21 & NS & & 21 & NS \\
\hline Vege.dec & & 88 & NS & & 72 & NS & & 76 & NS & & 79 & NS \\
\hline Perc.water & & 88 & NS & -0.005 & 72 & 0.054 & & 76 & NS & & 79 & NS \\
\hline Topsoil*nurse1 & & 88 & NS & & 72 & NS & & 76 & NS & & 79 & NS \\
\hline Topsoilnurse2 & & 22 & NS & -0.262 & 22 & 0.086 & & 21 & NS & & 21 & NS \\
\hline Topsoil*Weedmat & & 22 & NS & & 22 & NS & & 21 & NS & & 21 & NS \\
\hline Topsoil*vege.dec & & 88 & NS & & 72 & NS & & 76 & NS & & 79 & NS \\
\hline Topsoil*perc.water & & 88 & NS & & 72 & NS & -0.002 & 76 & $0.0002^{\star \star \star}$ & & 79 & NS \\
\hline Nurse $1^{*}$ weedmat & & 88 & NS & & 72 & NS & & 76 & NS & & 79 & NS \\
\hline Nurse2*weedmat & & 88 & NS & & 72 & NS & & 76 & NS & & 79 & NS \\
\hline Nurse $1^{*}$ vegetation & & 88 & NS & 0.006 & 72 & $0.042^{*}$ & & 76 & NS & & 79 & NS \\
\hline Nurse2*vegetation & & 88 & NS & 0.004 & 72 & 0.093 & & 76 & NS & & 79 & NS \\
\hline Nurse1*perc.water & & 88 & NS & & 72 & NS & & 76 & NS & & 79 & NS \\
\hline Nurse2*perc.water & & 88 & NS & & 72 & NS & & 76 & NS & & 79 & NS \\
\hline Weedmat*vege.dec & & 88 & NS & & 72 & NS & & 76 & NS & & 79 & NS \\
\hline Weedmat ${ }^{*}$ perc. water & & 88 & NS & & 72 & NS & & 76 & NS & & 79 & NS \\
\hline Vege.dec* perc.water & & 88 & NS & & 72 & NS & 0.000 & 76 & 0.043 & & 79 & NS \\
\hline Variance components & & & & & & & & & & & & \\
\hline$\%$ Var. Between blocks & & & 0.016 & & & 0.191 & & & 0.048 & & & 0.000 \\
\hline$\%$ Var. Between plots & & & 0.000 & & & 0.000 & & & 0.000 & & & 0.037 \\
\hline $\begin{array}{l}\text { \% Var. Between } \\
\text { individuals }\end{array}$ & & & 0.984 & & & 0.809 & & & 0.953 & & & 0.964 \\
\hline
\end{tabular}




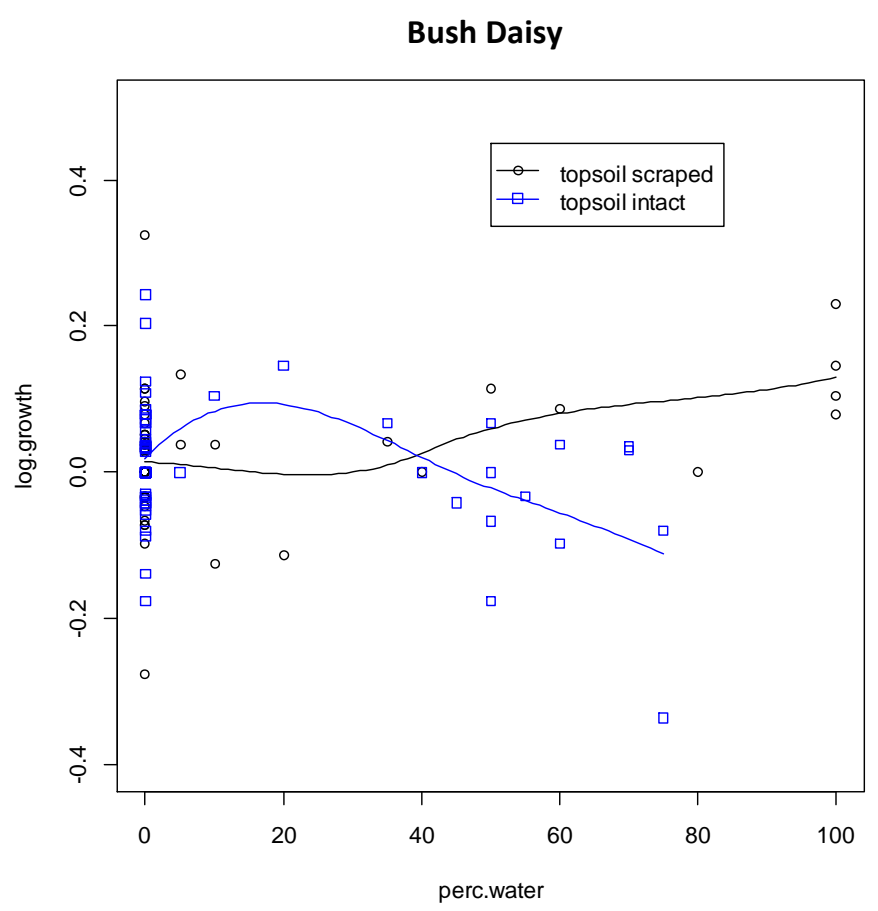

Figure 31 Log growth $\left(\log _{10}\right)$ of $O$. virgata in relation to percentage water cover and the treatment topsoil. Lowess lines have been added to emphasise general trends.

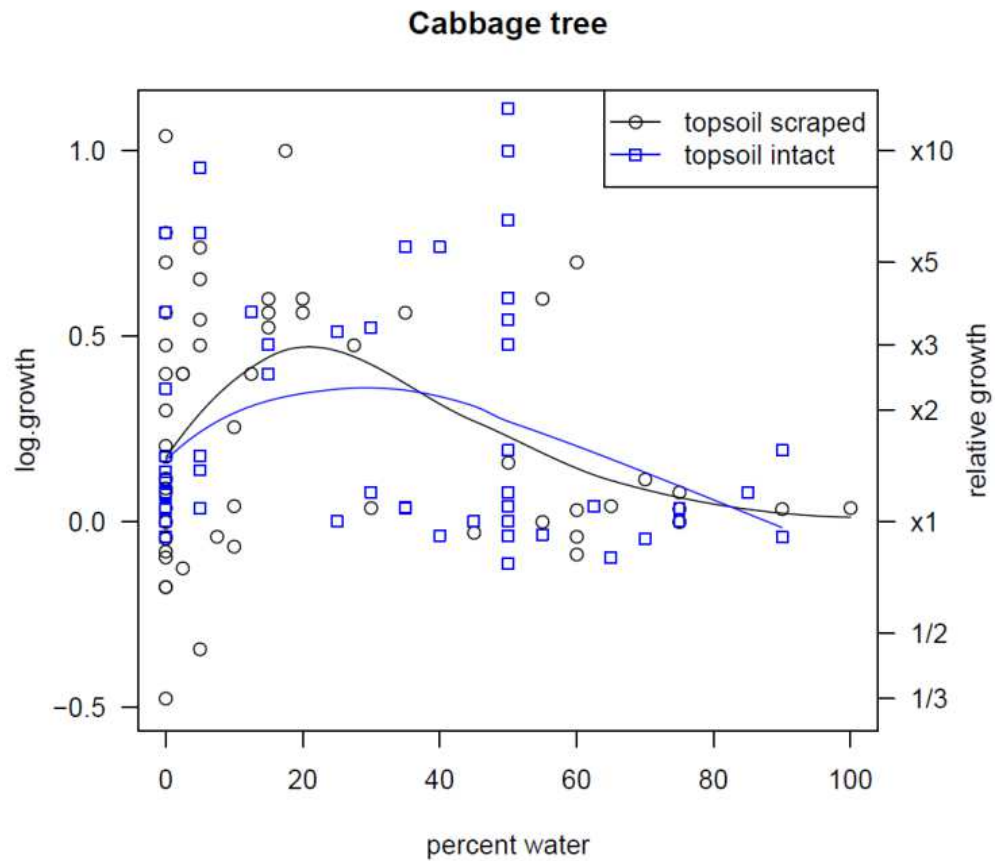

Figure $32 \mathrm{Log}$ growth $\left(\log _{10}\right)$ of $C$. australis in relation to percentage water in December 2011, and the treatment of topsoil. Lowess lines have been added to emphasise general trends. 


\section{Discussion}

\section{Cost-Benefit Analysis of Survival}

The aim of this study was to determine the best and most cost-effective combination of treatments for successful establishment for tree saplings over the first six months. Overall, the most cost-effective combination appeared to be the least-interventionist with unscraped topsoil, no weedmat and no nurse tree at a cost of $\$ 2.77$ per surviving focal tree growth (see Figure 27 and Table 20). The least cost-effective combination was scraped topsoil, Coprosma nurse trees and weedmats, at a cost of $\$ 27.19$ per surviving focal tree. In reference to particular species, the CBA indicated the most cost-effective treatment combination is $C$. australis subjected to unscraped topsoil with no nurse trees, the cost per surviving focal tree is $\$ 1.93$. The least cost-effective combination is $P$. totara with scraped topsoil, Coprosma nurse trees and weedmats, at a cost of $\$ 36.50$ per surviving tree.

Overall tree survival rates were 92.38\%. Despite not yet having a full years set of data, this is comparatively higher than previous years where survival of native trees at Wairio wetland has been $50 \%$ to $75 \%$ (Silbery, 2011). Survival of focal species was $97.87 \%$ for D. dacrydioides, $93.17 \%$ for O. virgata, $91.30 \%$ for $P$. totara and $87.20 \%$ for $C$. australis. From the field it was interesting to observe that $63 \%$ of the C. australis were either half or fully subjected to herbivory from an unknown species which gave the appearance of negative growth (Figure 29); and $P$. totara saplings had elongated growth in wet areas, but this did not show as significant. Dacrycarpus dacrydioides is the most successful and most cost effective species. Cordyline australis, along with $P$. totara, were the least successful species, but proved the most cost-effective treatment when subjected to spraying and no nurse trees. The most successful management techniques had $100 \%$ focal species survival. These were scraped with nurse trees $L$. scoparium and $P$. tenuifolium and weedmats and also scraped with nurse trees $L$. scoparium and $P$. tenuifolium. The least successful management techniques had $87.5 \%$ focal species survival, these were scraped with Coprosma nurse trees, weedmats and scraped with Coprosma nurse trees. An important caveat is that the native trees planted have only been subjected to six months of treatments, which may not have been long enough for them to have any significant effect, especially for the nurse trees and weedmats, which 
perhaps had not had time to pay for themselves (with subsequent spraying continually being required without them).

The value of the nurse trees was not included in the cost benefit, as their success was considered incidentally to this study. However, in regard to overall restoration, survival of any planted sapling would be counted as valuable success. The aim of our study was to examine the effectiveness of different treatments, but the main consideration of wetland revegetation projects should be the total area of land that has been 'forested' with planted trees, whether that be through aiming for $100 \%$ survival, or simply sufficient survival to recreate a natural habitat or to achieve an ecosystem service such as reducing nutrient inputs into the lake.

A lot of research focuses on the bigger picture of wetland restoration and not the small detail on developing successful treatments for plant survival. Although several New Zealand Regional Councils (Auckland, Waikato, Wellington and Canterbury) and Landcare offer opinions on how to revegetate wetlands through providing Wetland planting guides. In these, they make suggestions on native plant species suitable for the different wetland types and the zones within them, fencing off the restoration area, preplanting weed control, assorted planting distances and hole depths, staking plants for stability and easy visibility, the most beneficial size plants to use, the best time to plant trees and post-planting care (Greater Wellington Regional Council, 2009; Clarkson and Peters, 2010; Environmental Canterbury Regional Council, 2011; Auckland Regional Council, 2012; Waikato Regional Council, 2012). However, these guides provide no specific information on the relative success rate and the cost of the different treatment methods.

In determining the most cost-effective combination of treatments for establishment of tree saplings, treatments were found to have little effect on native species. The initial conclusion is that the cheapest option of spraying with no weedmat and no nurse trees is the most beneficial. Continued monitoring of the focal trees over the next two to three years will allow stronger conclusions to be drawn regarding the most cost-effective treatment combinations and broaden our understanding of successful establishment of native tree saplings. 


\section{Experimental Treatments, Effects on Growth Rates}

Our results showed that the survival of two focal species, $O$. virgata and $P$. Totara, were significantly influenced by the presence of surface water. They were more likely to survive with a lower percentage of water cover. No other treatment or species were found to be significant in the survival of the species. Four significant patterns were observed in two of the focal tree species at Wairio wetland. Olearia virgata growth was positively affected by two treatments 'scraped topsoil with little surface water present', and 'high cover of plants with high cover of surrounding water'. The growth of $C$. australis increased with 'the combination of $L$. scoparium and $P$. tenuifolium nurse trees with a greater cover of surrounding plants', and 'the treatment of unscraped topsoil'. Percent plant cover, percentage water and topsoil scraped or unscraped were the most common factors affecting focal species. Overall, the survival rates of focal species were relatively high, resulting in low variance between treatment effects. Due to the many tests performed, only one result is classified as truly significant after Bonferonni testing; that is; topsoil scraped with low cover of surface water considerably increases the growth of $O$. virgata. There appeared to be no effect of the site preparation and aftercare treatments on the initial growth of the other two focal species, kahikatea and totara.

Based on the known natural history of the focal species, assumptions can be made about the reasons behind the growth rate patterns. Olearia virgata had the most significant growth rate with scraped topsoil in combination with no or little surface water present and was most significantly affected by surface water in regard to its survival. It is known that $O$. virgata is not overly tolerant of damp soils and needs full sun light (New Zealand Plant Conservation Network, 2010). As this species prefers extended periods of sun and relative dry soils, the combination of dry soils and scraped topsoil (removing competing species) was beneficial for its growth. Following the mid-year planting at Wairio wetland, some treatment blocks were consistently submerged, possibly causing the low growth or high mortality of the O. virgata. Newly planted flaxes and C. australis are attractive food source to both pukeko and rabbits (New Zealand Plant Conservation Network, 2010). Evidence of herbivory on C. australis at Wairio wetland was evident in around $63 \%$ of the trees. This species had greater growth rates when surrounded by nurse trees, combined with denser cover of weeds, or in areas of unscraped topsoil. It is 
likely that it was harder for herbivores to locate $C$. australis when surrounded by dense plant cover. Our results show that out of the four focal species, both $D$. dacrydioides and $P$. totara are the species expected to cope with flooding and high soil moisture. This was evident with the $D$. dacrydioides and its $100 \%$ survival rate.

It is perhaps too early to properly assess the functional success of the treatments, as the native trees have had only six months growth before measurements were made. We would not expect tree spacing or nurse species to have much influence over growth in the first six months, but this could change over the next few years. One treatment in particular has been widely reported to assist in the success of seedling establishment the use of nurse trees (Padilla and Pugnaire, 2006). It is reasonable to conclude that nurse trees at Wairio wetland have not yet had the chance to be effective in providing shade for focal species, protection from herbivores, or obstructing competition from invasive weeds. Studies show that survival of seedlings of many species increases when transplanted into the shade of nurse trees when compared with those planted in the open (Callaway, 1995). As the current nurse trees provide little shade or shelter from invasive weeds for the focal species, their true benefit may not be evident for several years. Significant results will perhaps arise from Wairio wetland when the 'advance' focal trees are planted and can be measured for success. As Callaway (1995) found, the use of pre-established vegetation as nurse trees is more effective as a restoration technique when the focal species are woody plants. Nurse/focal tree relationships exist or are more obvious during the early stages of primary succession (Chapin et al., 1994); and six months growth is likely too early in the successional stages for patterns to emerge. If a delayed effect of nurse trees is found, further studies could examine interactions along the hydrological stress continuum to test for effects of nurse trees at different moisture gradients. Bertness and Shumway (1993) found at the most environmentally stressful part of a salt marsh, focal species respond positively to the influence of nurse trees. One idea to consider is that the established exotic grasses are initially acting as nurse plants to the young seedlings, hence the increased growth of $C$. australis in the presence of more plant cover (predominantly exotic grasses, see Chapter two).

Surface water was found to significantly decrease the growth of $O$. virgata, in combination with topsoil removal. This result is contradictory of the Fraser and Karnezis' 
(2005) study in North American marshes and wet meadow wetlands on covering broad range of plant types, which suggested that recently planted seedlings should not be submerged in water; although, if this is unavoidable, annuals or sedges should be planted as they are more likely to tolerate extended periods of flooding. Seabloom et al. (2003a) found the composition of seedling communities and stem count are negatively affected by the water depth into which they are planted. Casanova and Brock (2000), however, found that water depth was the least important factor in segregating plant communities, but the duration and frequency of flooding events were most important in influencing plant community composition.

Survival of the planted trees throught the first six months (June to December 2011) has been high, hence it is too early to draw strong conclusions about the best treatments and environmental conditions for growth of the planted species. However, the experimental design and continued moitiring of the plants over the next 2-3 years will provide much useful information. 


\section{References}

Angelsen, A., Sumaila, U.R., 1995. Hard Methods for Soft Policies: Environmental and Social Cost-Benefit Analysis, Chr. Michelsen Institute, Development Studies and Human Rights. Bergen, Norway.

Aronson, J., 2006. Ecological restoration: a frontier for nature conservation and economics. Journal for Nature Conservation 14, 135-139.

Auckland Regional Council, 2012. Wonderful Wetlands: Wetland Restoration and Planting Guide for the Auckland Region., Auckland Regional Council Auckland, New Zealand.

Bertness, M.D., Shumway, S.W., 1993. Competition and facilitation in marsh plants. American Naturalist 142, 718-724.

Callaway, R.M., 1995. Positive Interactions among Plants. The Botanical Review 61, 306-349.

Casanova, M.T., Brock, M.A., 2000. How do depth, duration and frequency of flooding influence the establishment of wetland plant communities?. Plant Ecology 147, 237-250.

Chapin, F.S., Walker, L.R., Fastie, C.L., and Sharman, L.C., 1994. Mechanisms of primary succession following deglaciation at Glacier Bay, Alaska. Ecological Monographs 64, 149-175.

Chazdon, R., L., 2008. Beyond Deforestation Restoring Forests and Ecosystem Services on Degraded Lands. Science 320, 1458-1460.

Clarkson, B., Peters, M., 2010. Revegetation, in: Peters, M., Clarkson, B. (Eds.), Wetland Restoration: A Handbook for New Zealand Freshwater Systems. Landcare, New Zealand.

Cramer, V.A., Hobbs, R.J., and Standish, R.J., 2008. What's new about old fields? Land abandonment and ecosystem assembly. Trends in Ecology and Evolution 23, 104112.

Department of Labour, 2011. The Minimum Wage http://www.dol.govt.nz/er/pay/minimumwage/. Downloaded December 2011.

Edwards, P.J., Abivardi, C., 1997. Ecological engineering and sustainable development, in: Urbanska, K.M., Webb, N.R., and Edwards, P.J. (Eds.), Restoration ecology and sustainable development. Cambridge University Press, New York, pp. 325352.

Enright, P., Olaf, J., and Silbery, Y., 2008. Vascular plants Wairio wetlands, Lake Wairarapa, Wairio Wetland, Lake Wairarapa. 
Environmental Canterbury Regional Council, 2011. Creating and managing wetlands - wetland planting guide. Environmenat Canterbury Regional Council, Christchurch, New Zealand.

Ewel, K.C., 1991. Diversity in Wetlands. Evolutionary Trends in Plants 5, 90-92.

Fraser, L.H., Karnezis, J.P., 2005. A Comparative Assessment of Seedling Survival and Biomass Accumulation for Fourteen Wetland Plant Species Grown Under Minor Water-Depth Differences. Wetlands 25, 520-530.

Gosselink, J.G., Turner, R.E., 1978. The Role of Hydrology in Freshwater Wetland Ecosystems, in: Good, R.E., Whigham, D.F., and Simpson, R.L. (Eds.), Freshwater Wetlands: Ecological Processes and Management Potential Academic Press, New York, pp. 63-78.

Greater Wellington Regional Council., 2009. How do I restore a wetland?: Start Planting. Greater Wellinton Regional Council Wellington, New Zealand.

Gren, I., Folke, C., Turner, K., and Bateman, I., 1994. Primary and Secondary Values of Wetland Ecosystems. Environmental and Resource Economics 1, 22-74. 267.

Holl, K.D., Howart, R.B., 2000. Paying for Restoration. Restoration Ecology 8, 260-

Holling, C.S., 1986. The resilience of terrestrial ecosystems: local surprise and global change, Sustainable Development of the Biosphere. Cambridge University Press, Cambridge, pp. 292-317. $15-21$

King, D.M., 1991. Costing out restoration. Restoration and Management Notes 9,

Luken, J.O., 1990. Directing ecological succession. Chapman and Hall, London.

Microsoft Corporation, 2010. Microsoft Office Excel. Microsoft Corporation, Santa Rosa, California.

New Zealand Plant Conservation Network, 2010. http://www.nzpcn.org.nz/. Downloaded March 2012. York.

Odum, H.T., 1983. Systems Ecology: An Introduction. John Wiley and Sons, New

Office of Wetlands Protection, 1989. Forward, in: Kusler, J.A., Kentula, M.E. (Eds.), Wetland Creation and Restoration: The Status of the Science, US EPA Environmental Research Laboratory Corvallis, Oregon.

Padilla, F.M., Pugnaire, F.I., 2006. The role of nurse plants in the restoration of degraded envrionments. Frontiers in Ecology and the Environment 4, 196-202. 
Petranka, J.W., McPherson, J.K., 1979. The role of Rhus copallina in the dynamics of the forest-prairie ecotone in north-central Oklahoma. Journal of Ecology 60, 956-965.

Pinheiro, J., Bates, D., DebRoy, S., and Sarkar, D., 2012. nlme: Linear and Nonlinear Mixed Effects Models R package version 3.1-103.

R Development Core Team, 2011. R: A language and environment for statistical computing. , R Foundation for Statistical Computing. Vienna, Austria.

Seabloom, E.W., Harpole, W.S., Reichman, O.J., and Tilman, D., 2003. Invasion, competitive dominance, and resource use by exotic and native California grassland species. Proceedings of the National Academy of Sciences USA 100, 13384-13389.

Siemann, E., Rogers, W.E., 2003. Changes in light and nitrogen availabilty under pioneer trees may indirectly facilitate tree invasions of grasslands. Journal of Ecology 91, 923-931.

Silbery, T., 2011. Personal communication with Tony Silbery: biodiversity ranger for the Deparment of Conservation, Wellington Hawke's Bay conservancy, December 2012.

Smit, C., Vandenberghe, C., den Ouden, J., Muller-Scharer, H., 2007. Nurse plants, tree saplings and grazing pressure: changes in facilitation along a biotic environmental gradient. Oecologia 152, 265-273.

United States Environmental Protection Agency., 1995. Evalutating the Costs Effectiveness of Restoration Restoration. http://water.epa.gov/type/watersheds/archives/chap5.cfm. Downloaded December 2011.

Waikato Regional Council, 2012. Restoring a Wetland - Wetland planting guide, Waikato Regional Council, Hamilton, New Zealand.

Walker, L.R., Del Moral, R., 2003. Primary succession and ecosystem rehabilitation. The Press Syndicate of the University of Cambridge, Cambridge.

Walker, L.R., Willig, M.R., 1999. An introduction to terrestrial disturbances, in: Walker, L.R. (Ed.), Ecosystems of Disturbed Ground, Elsevier Science, Amsterdam, Netherlands, pp. 1-15.

Zedler, J.B., 2000. Progress in wetland restoration ecology. Trends in Ecology and Evolution 15, 402-407.

Zedler, J.B., 2005. Ecological restoration: guidance from theory, San Francisco Estuary and Watershed. Science 3, 1-31. 


\section{Appendix 3}

\section{Appendix 3.1}

Table 23 Classification of treatment costs at Wairio wetland.

\begin{tabular}{llr}
\hline Treatment & Quantity required & Cost (\$NZ) \\
\hline Alutags & Pack of 1000 & 81.44 \\
Spot spraying & 6 hours labour plus herbicide & 343.28 \\
Release spraying & 6 hours labour plus herbicide & 343.28 \\
Topsoil scraping & 7 hours @ 133.57/hour & 935.00 \\
Total tree cost & 2368 native trees & $4,993.60$ \\
Weedmats & 1728 & $2,571.52$ \\
Block markers & 60 stakes @ 3.90 each & 234.00 \\
Advance markers & 256 pegs @ \$0.66 each & 384.00 \\
Total cost & & $9,804.68$ \\
\hline
\end{tabular}




\section{4}

\section{CONCLUSIONS AND RECOMMENDATIONS}

In the following chapter, the key findings of the two parts of this thesis are presented and conclusions drawn. The main aim of this thesis was to conduct scientific research to advise the management and ecological restoration objectives of the Wairio wetland. This thesis was divided into two parts determining the effect of soil moisture and scraping of topsoil on the distribution of key native and exotic plant species (Chapter two); and investigating the cost effectiveness of management treatments that influence the establishment and short term growth of planted native trees at Wairio wetland (Chapter three).

\section{Summary of Key Findings}

\section{Influence of soil moisture and removal of topsoil}

The Wairio wetland plant community displays strong patterns of zonation associated with gradients of hydrological stress. There is a plant sequence from aquatic species at the wet end of the gradient, to turf communities, to exotic grass species. Results show that in soil that has a low level of moisture the dominant species are common introduced pasture grasses, especially $H$. lanatus, $A$. capillaris and $F$. arundinacea as well as the clover T. pratense; in conditions of high soil moisture the dominant species is water plantain (Alisma spp.); and under conditions of intermediate soil moisture the exotic competitor G. maxima is relatively abundant. Native turf species $G$. elatinoides and $L$. perpusilla are restricted to a small band of highly moist sites, the last zone to be exposed 
by the retreating water margin. With knowledge of the species competing with these turf natives, it is possible to recommend management strategies to preserve and restore their narrow range of habitat. I propose precise hand removal of exotic species in the zone of these turf species, no artificial water control in the areas where they exist, and further monitoring to document if and when their habitat expands.

Removing topsoil is a common strategy for revegetation restoration projects. Our results found that excavating topsoil indeed impacts the plant community, as a difference was found in the species composition between the two site-preparation methods. Grass species such as $F$. arundinacea and $A$. capillaris prefer areas that had been disturbed by mechanical scraping of the topsoil, whereas species $L$. tenuis, $T$. repens, $A$. cotula, $L$. hyssopifolia and $H$. lanatus were more abundant in unscraped soils. Regardless of soil moisture, topsoil scraping initially created a more sparse plant community, allowing for more successful establishment of native turf species.

\section{Processes influencing the establishment of planted trees}

The early effect of topsoil removal found at Wairio wetland is consistent with previous research conducted on the establishment of focal species in wetlands. Three studies on fen wetlands in Poland and Germany, which focused on wetland reed and grass species, showed that when topsoil is removed, the newly established plants are more effective invaders, agricultural grasslands are suppressed, rare species have greater chance of success and slow-growing focal species with low competitive ability are promoted (Ramseier, 2000; Patzelt et al., 2001; Rasran et al., 2007). Three reasons are hypothesised for the success of topsoil removal. Firstly, the relative water table changes. At Wairio wetland, the scraped areas tended to collect water relative to the adjacent unscraped areas, which can create unfavourable conditions for woody plants due to water level fluctuations. However, for some aquatic plant species lowering the soil surface closer to the water table is a beneficial manoeuvre. Secondly, competing plant species are removed, giving the focal species an advantage. And thirdly, topsoil removal modifies the soil nutrient conditions, as it accelerates nutrient impoverishment, hence benefitting slower-growing native species over exotic species used for productive pastures. 
Initial results show few significant differences in regard to which management treatments are most successful in establishing planted native trees. Preliminary indications suggest high survival of the focal species under all the treatments. The little mortality that occurred is best explained by excessive inundation by surface water, with $P$. totara and $O$. virgata showing higher survival in the relatively drier sites. There is some indication that cabbage trees grew best in sites of intermediate water cover (around 10-40\% in December) and $O$. virgata appeared to grow best in wet areas that had been scraped free of topsoil or drier areas that had not been scraped. The most cost-effective combination of treatments over the first six months of growth was thus the "low intervention" option of unscraped topsoil, with no weedmat or nurse tree (\$2.77 per surviving focal tree). However, this option does not come as a recommendation from the author, even though this is what most council best-practice guides would indeed recommend (Greater Wellington Regional Council, 2009; Clarkson and Peters, 2010; Environmenat Canterbury Regional Council, 2011; Auckland Regional Council, 2012; Waikato Regional Council, 2012). This is because monitoring over the next 18 months should provide further information on which is truly the most cost-effective combination of treatments.

\section{Restoration Recommendations for Wairio Wetland}

This research covered only a small proportion of the overall issues required for comprehensive wetland restoration. Several common wetland functions will require consideration and further investigation if the Wairio wetland is to be holistically restored. Key functions requiring the most urgent attention are hydrological control along with weed and pest control. In the author's opinion the other functions that will require consideration include:

- Increasing biotic diversity and wildlife habitat (including increased populations of aquatic species);

- Spatial distribution of plant and organic matter (forming the basis of aquatic food chains);

- Recreational opportunities and aesthetics, sediment retention and sinks for pollutants and excess nutrients (Office of Wetlands Protection, 1989). 
Little detail is known about the hydrological functioning of the Wairio wetland. Further investigation is needed regarding water storage and the effects of artificial ponds; the movement of water in and out of the wetland, including temporal sequences of water depths and the magnitude and frequency of high water levels; how the hydrology affects plants, animals and the soil, both locally and across the whole catchment community; and the effect of restoration of natural hydrological regime across the catchment. Campbell (2010) constructed a list of common goals for restoring natural hydrological function to a wetland, which I recommend the Wairio wetland project considers implementing as a foundation strategy. These include improving upstream water quality by removing stock from collective water sources, planting of riparian areas, altering water levels to alleviate weed invasion and creating suitable habitat for native fish.

The natural progression from restoration of hydrological function would be to focus on weed control, revegetation and pest control. Two of which were partially reviewed in this thesis. Weeds are often the most visual sign of human destruction in a wetland (Bodmin, 2010). Visitors to Wairio wetland often comment that it just looks 'like a soggy, grassy paddock". Effective weed control is achieved through identification of the weed issues (Chapter two), selection and application of appropriate treatment methods and timing of work and consistent follow up and monitoring (Bodmin, 2010). Bodmin (2010) offers weed control goals which could be incorporated into the Wairio wetland restoration plan, such as reduce the crack willow (Salix fragilis) populations along the wetland's western boundary and at Boggy Pond, reduce reinvasion of weeds by creating buffer zones and restoring water inflow and outflows, and continue to determine high priority weeds, and control in the most intact sections of the wetland first. Frequent surveillance should be carried out to survey the establishment of new weed populations so they can be rapidly eradicated, even if they are important food sources for local fauna. Revegetation should occur alongside weed control; Chapter three focuses on cost-effective planting techniques, but other revegetation goals could be considered for the Wairio wetland, including providing food and habitat for native fauna and creating a seed source for further restoration endeavours. As the plants continue to mature, the short-term revegetation goals should continue to be refined and specialised (Clarkson and Peters, 2010). 
Research on the effects of wetland pest species in New Zealand is scarce (Watts and Peters, 2010). However, based on experiences of other ecosystems it is known that rodents, mustelids, cats and hedgehogs eat bird eggs and chicks, that grazing animals target native plants and that introduced fish and insects negatively affect native aquatic species. Most of these pest species disturb the Wairio wetland. Apart from the three areas that are fenced to exclude farm animals, no other pest control has been implemented to date. Before undertaking animal pest control, a list of priority species requiring protection ought to be made. The recommended goals for pest control at the Wairio wetland come from Watts and Peters (2010) control grazing animals (deer, hare and rabbits) to protect newly established native saplings, protect these saplings from pukeko by using plant protection hedging or cages, manage magpie populations as they can be territorial and aggressive towards native birds and conduct year-round control of mustelids and rodents to protect nesting birds. Aquatic pests are difficult to manage as their distribution is hard to control; specialist skills are often required for eradication management.

\section{Implications of this Research}

Although it is too early to evaluate the benefits of the imposed treatments at Wairio wetland, this study has raised a number of important issues regarding restoration and revegetation of wetlands. An interaction between exotic grasses and planted native trees has been observed. Tall fescue (Schedonorus arundinaceus) was originally hypothesised to be the main reason for failure of sapling survival. However, this study would argue that water-logging and difficulty with finding the native trees (for regular spot spraying of herbicide) are the most common causes of death. Tall fescue may be a cause of death through competition, but this can be potentially alleviated through regular release spraying, which requires the trees to be locatable on a regular basis. Even with the native trees planted in patterns, locating species six months after planting during the desiccation period was difficult, although logically easier than if tree locations had been more randomly distributed. Although the nurse trees at Wairio wetland have not yet been effective in protecting the focal species, the exotic grasses, to some extent seemed to provide similar results to those we would expect from the nurse trees. For example, newly established $C$. australis at the Wairio wetland showed positive growth when surrounded by nurse trees, or in dense cover of weeds, or in areas of unscraped topsoil. 
As herbivory was largely evident in this species, it seems the grasses were acting as cover from herbivores. Another future technique that could be attempted is the use of rabbit protection covers.

\section{Summary of Recommendations for Current Practice}

There is potential for the Wairio wetland to become a reference site for other wetland restoration projects around Lake Wairarapa and in wider New Zealand. What we learn from this large-scale experiment can be applied to other current and future projects. Table 24 Suggestions of short and long term goals for plant restoration Wairio wetland to ensure holistic restoration. 
Table 25 Suggestions of short and long term goals for Wairio wetland to ensure holistic restoration

\section{Short term goals}

Annually monitor survival and growth of the native trees planted at Wairio wetland.

Widely distribute the results of survival and cost-benefit analysis as the native trees mature. Make the analysis methods available. E.g. via a page on www.NatureSpace.org.nz

Create buffer zones against invasive weeds around the Wairio wetland.

Initiate frequent surveillance for newly colonised weeds.

Establish information on the knowledgegap regarding the hydrological function of the Wairio wetland; and determine appropriate and achievable short and long term goals.

Compile a priority list of plant species requiring protection and formulate pest control strategy according; using information revealed in Chapter two regarding species distribution across the hydrological gradient and in scraped and unscraped soils.

Maintain relationship with wider community including Victoria University of Wellington, DOC, GWRC and DU to ensure a holistic approach to the wetland restoration.

\section{Long term goals}

Measure overall success of the wetland restoration (see below) and make the results widely available to other restoration groups.

Compile a priority list of fauna species requiring protection and formulate a pest control strategy accordingly.

Establish monitoring of pest species; preand post-implementation of pest control.

Establish monitoring of native fauna, especially avian and aquatic species; pre and post implementation of pest control.

Establish corridors of mature plants, successful hydrological functions and pest control between current stages of restoration at Wairio wetland. 
These goals are general statements about the desired project outcomes, with guides of importance. Turning these into tangible goals, however, will require setting time frames for anticipated achievement (Peters and Clarkson, 2010). Establishing a specific monitoring programme will enable the project to determine the overall success of the current restoration techniques and influence the direction of future management efforts (Weinstein et al., 1997; Peters and Clarkson, 2010). Generally, measuring the success of wetland restoration requires establishing a biologically sustainable wetland ecosystem (Mitsch and Wilson, 1996). Table 26 proposes criteria for general measures of wetland restoration success. Early success of management techniques should not be measured conclusively, but as a progression along the life of a long-term project (Weinstein et al., 1997).

Table 26 Proposed criteria for general measures of wetland restoration success (Office of Wetlands Protection, 1989; Clarkson and Peters, 2010).

\section{Measures of wetland restoration success}

High percentage of plantings survive through to maturity

Plants dominated by locally native species that are viable to support community-wide interactions

The ecosystem becomes self-sustaining

Lower frequency of invasive weeds becoming established

Frequency of native avian, fish and aquatic invertebrates species occurrence has increased

Pest species populations reach sustainable levels or the community should be resistant to invasive species

The wetland is not losing more nutrients than an undamaged reference site Increased percentage of open water

Well maintained in- and out-flows of ground and surface water 


\section{References}

Auckland Regional Council, 2012. Wonderful Wetlands: Wetland Restoration and Planting Guide for the Auckland Region., Auckland Regional Council Auckland, New Zealand.

Bodmin, K., 2010. Weeds, in: Peters, M., Clarkson, B. (Eds.), Wetland Restoration: A Handbook for New Zealand Freshwater Systems. Landcare, New Zealand.

Campbell, D., 2010. Hydrology, in: Peters, M., Clarkson, B. (Eds.), Wetland Restoration: A Handbook for New Zealand Freshwater Systems. Landcare, New Zealand.

Clarkson, B., Peters, M., 2010. Revegetation, in: Peters, M., Clarkson, B. (Eds.), Wetland Restoration: A Handbook for New Zealand Freshwater Systems. Landcare, New Zealand.

Environmental Canterbury Regional Council, 2011. Creating and managing wetlands - wetland planting guide. Environmental Canterbury Regional Council, Christchurch, New Zealand.

Greater Wellington Regional Council., 2009. How do I restore a wetland?: Start Planting. Greater Wellinton Regional Council Wellington, New Zealand.

Mitsch, W.J., Wilson, R.F., 1996. Improving the Success of Wetland Creation and Restoration with Know-How, Time, and Self-Design. Ecological Applications 6, 77-83.

Office of Wetlands Protection, 1989. Forward, in: Kusler, J.A., Kentula, M.E. (Eds.), Wetland Creation and Restoration: The Status of the Science, US. EPA Environmental Research Laboratory. Corvallis, Oregon.

Patzelt, A., Wild, U., and Pfadenhauer, J., 2001. Restoration of Wet Fen Meadows by Topsoil Removal: Vegetation Development and Germination Biology of Fen Species. Restoration Ecology 9, 127-136.

Peters, M., Clarkson, B., 2010. Goals and Objectives, in: Peters, M., Clarkson, B. (Eds.), Wetland Restoration: A Handbook for New Zealand Freshwater Systems. Landcare, New Zealand.

Ramseier, D., 2000. Why remove topsoil for fen restoration? Influence of water table, nutrients and competitors on the establishment of four selected plant species. Bulletin of Geobotanical Institute 66, 25-35.

Rasran, L., Vogt, K., and Jensen, K., 2007. Effects of topsoil removal, seed transfer with plant material and moderate grazing on restoration of riparian fen grasslands. Applied Vegetation Science 10, 451-460.

Waikato Regional Council, 2012. Restoring a Wetland - Wetland planting guide, Waikato Regional Council, Hamilton, New Zealand. 
Watts, C., Peters, M., 2010. Pests, in: Peters, M., Clarkson, B. (Eds.), Wetland Restoration: A Handbook for New Zealand Freshwater Systems. Landcare, New Zealand.

Weinstein, M.P., Balletto, J.H., Teal, J.M., and Ludwig, D.F., 1997. Success criteria and adaptive management for large-scale wetland restoration project. Wetland Ecology and Management 4, 111-127. 


\section{Appendix}

\section{Appendix 4.1 Photos from Wairio wetland.}

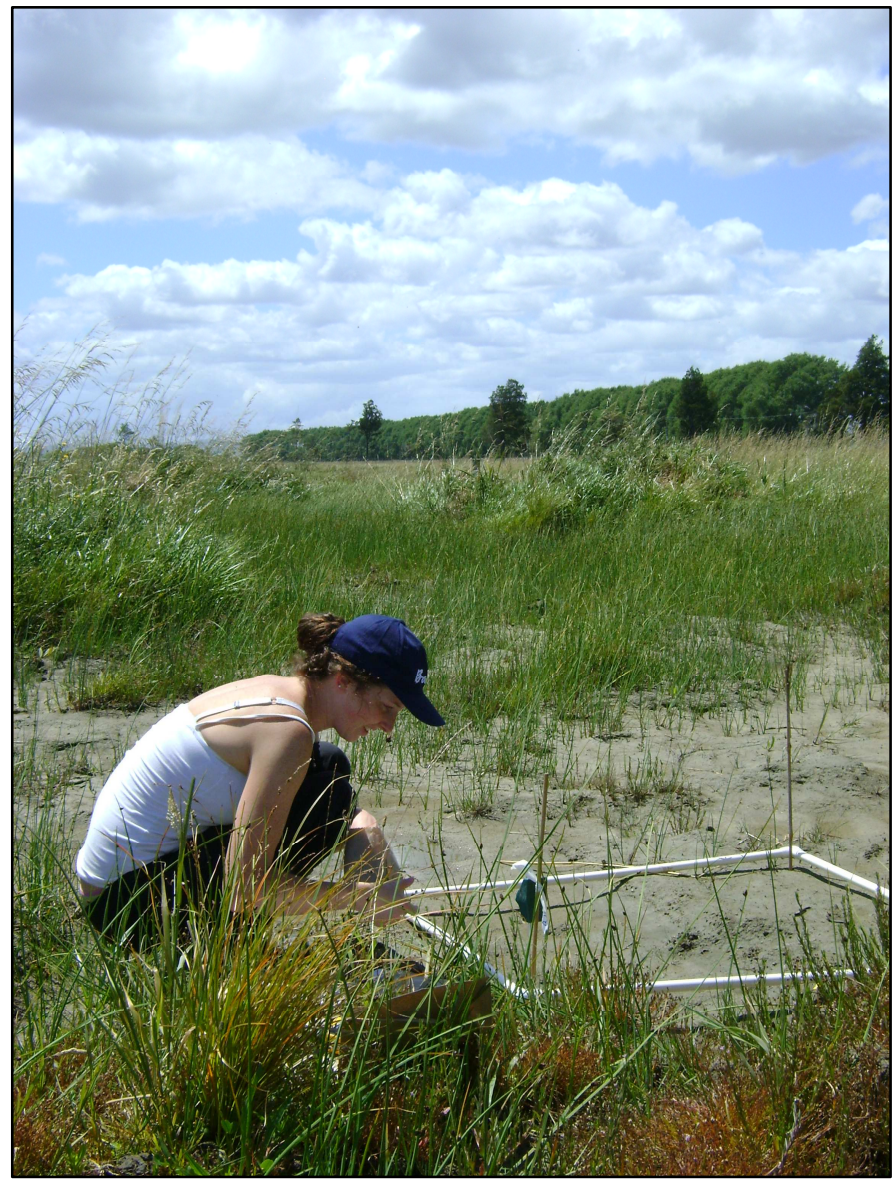

Figure 33 The author at Wairio wetland, Stage 1, measuring plant cover composition. Photo by Nathan Johnson. 13 ${ }^{\text {th }}$ January 2011. 

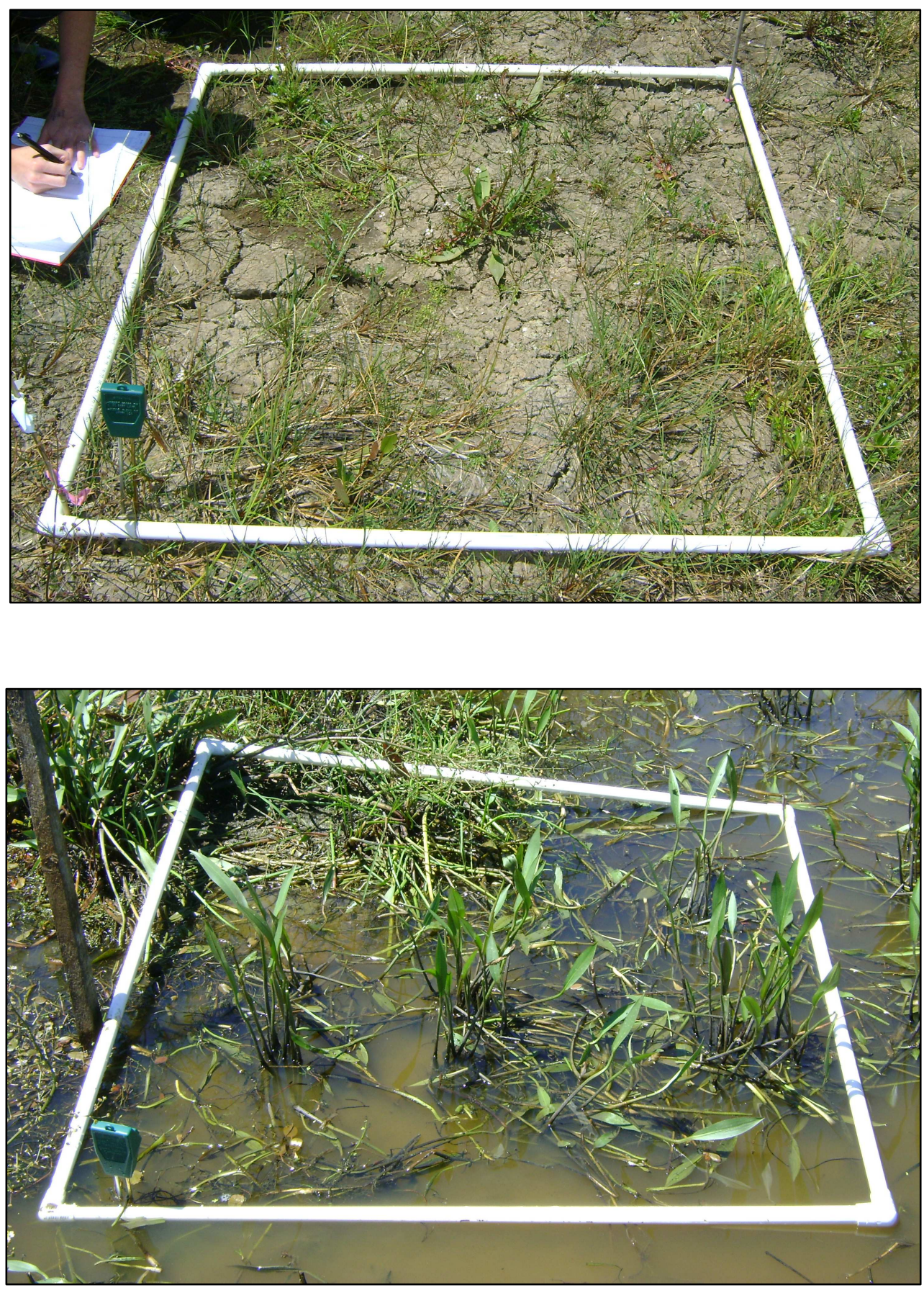

Figure 34 Wairio Wetland, Stage 1 along transect 1 A) Quadrat 1 B) Quadrat 10. Photo by Nathan Johnson, $13^{\text {th }}$ January 2011. 


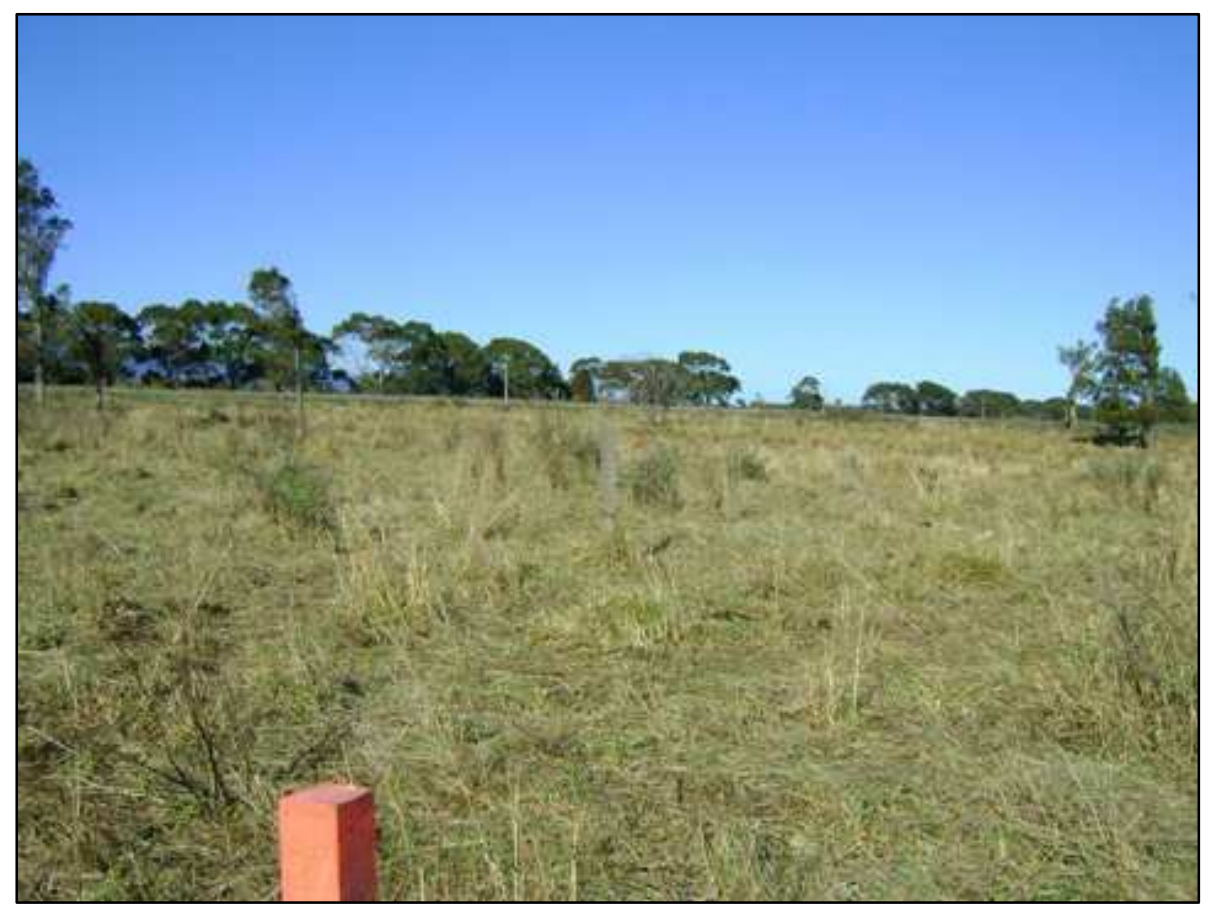

Figure 35 Wairio Wetland Stage 3, post cows, pre planting. Photo by D. Stephen Hartley, March 2011.

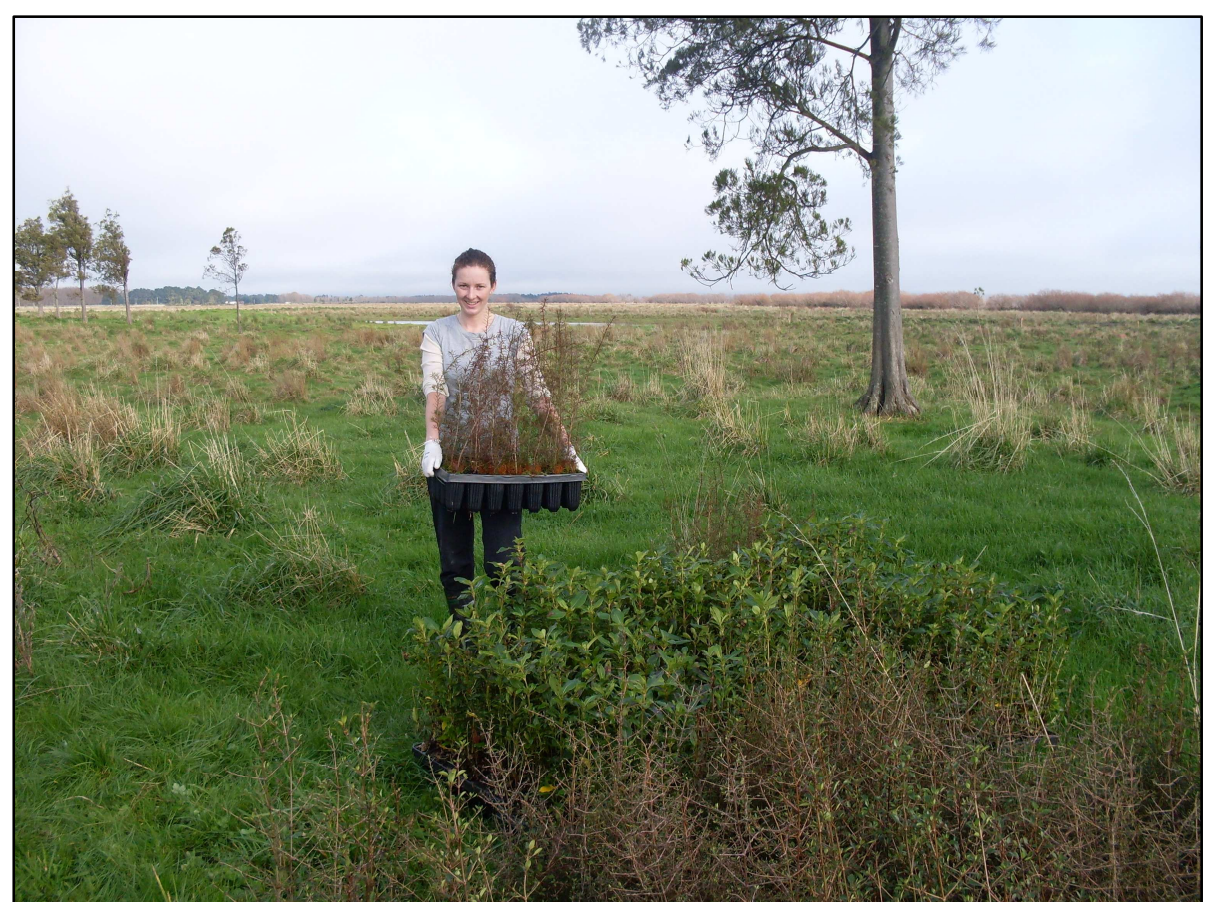

Figure 36 Wairio Wetland Stage 3, Author with some of the native saplings. Photo by Dr Stephen Hartley, June 2011. 


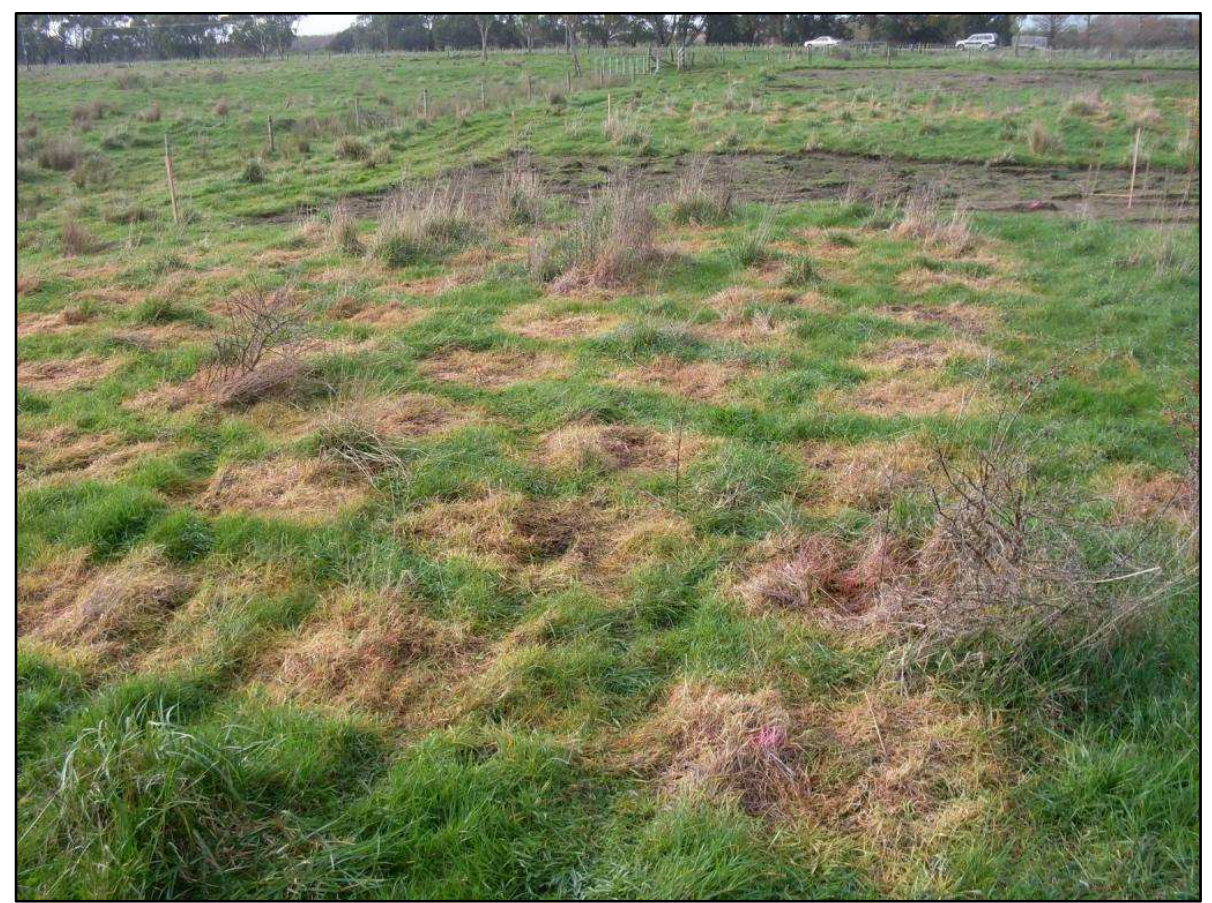

Figure 37 Wairio Wetland Stage 3, Block 7, unscraped topsoil, recently sprayed ready for planting (note pink dazzle paint where natives are to be planted). Photo by Dr Stephen Hartley, June 2011.

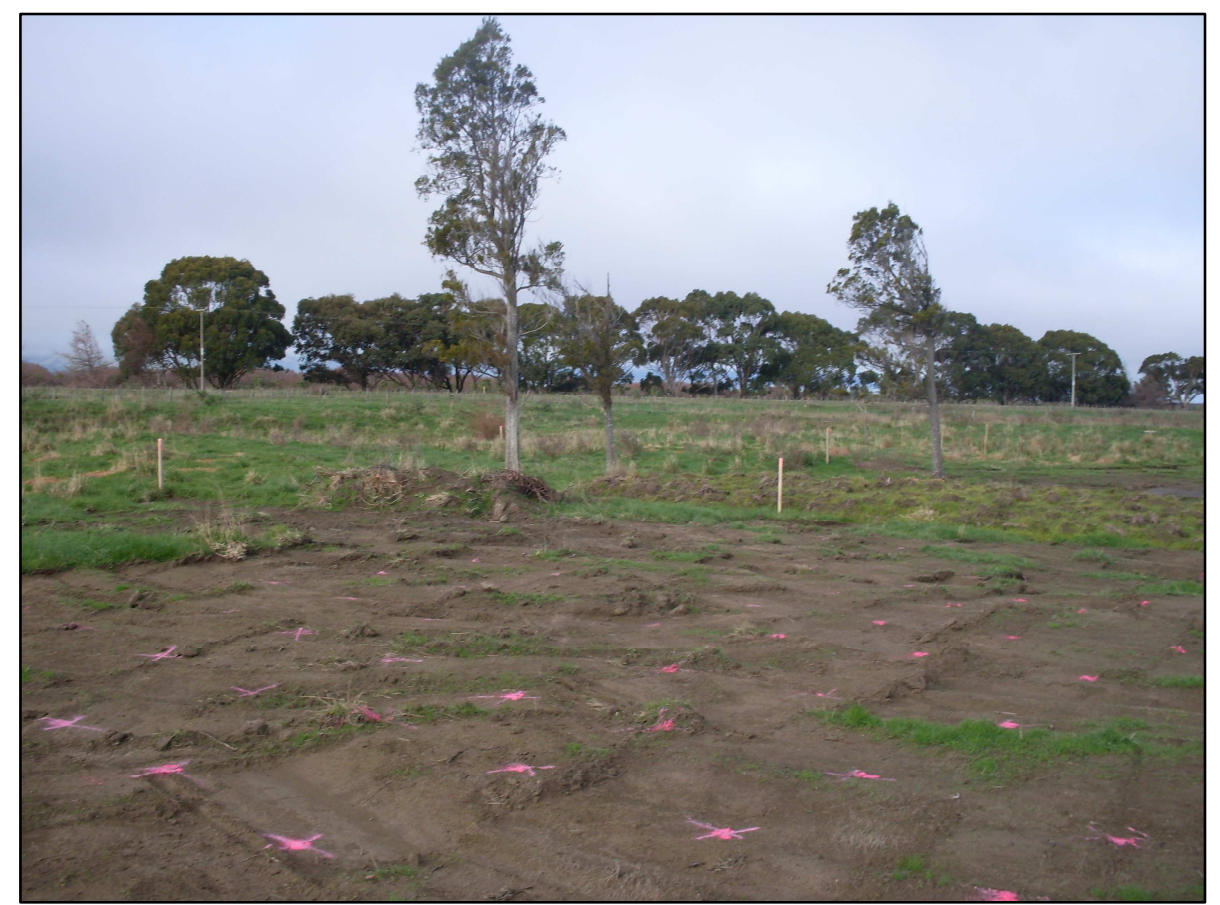

Figure 38 Wairio Wetland Stage 3, Block 7, scraped topsoil and ready for planting (note pink dazzle paint where natives are to be planted). Photo by Dr Stephen Hartley, June 2011. 


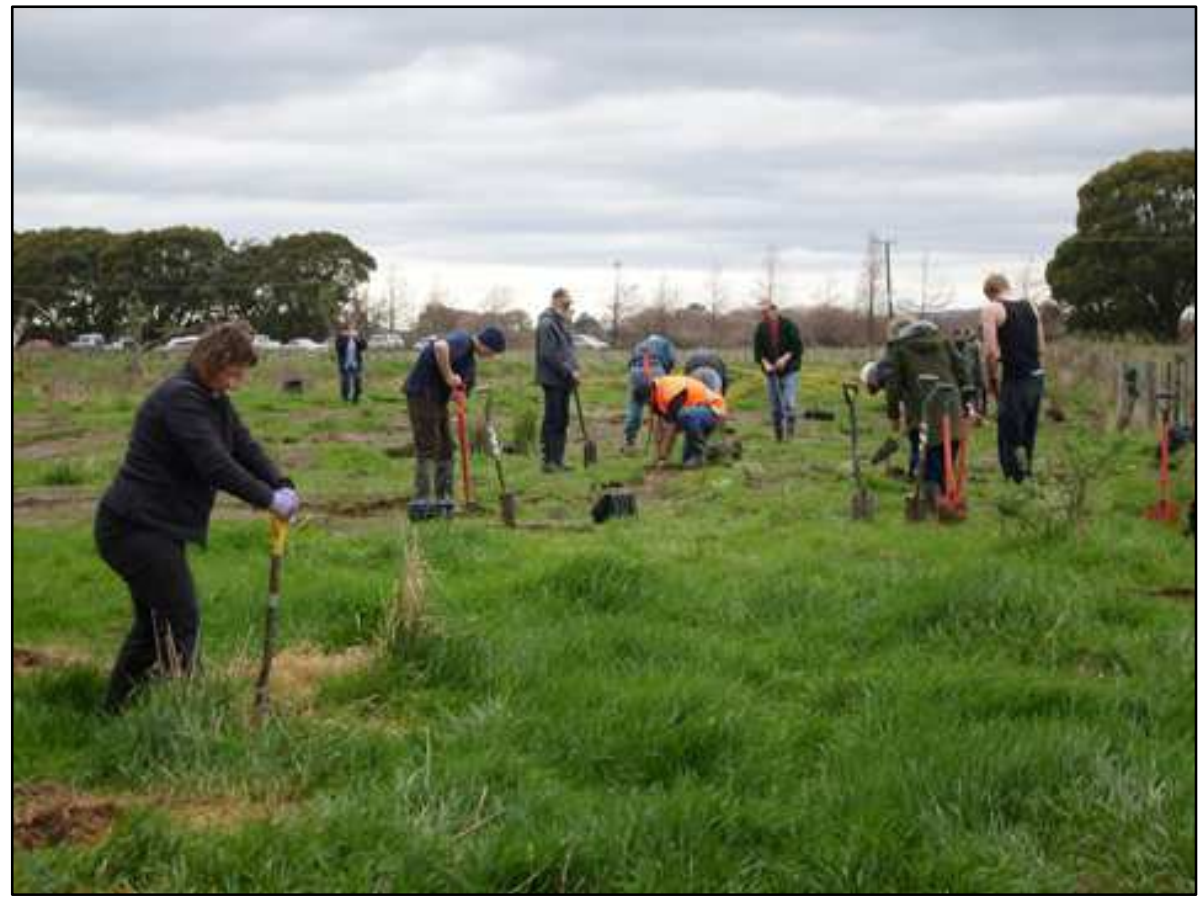

Figure 39 Wairio Wetland Stage 3, Volunteers planting native trees on planting day. Photo by $\mathrm{Dr}$ Stephen Hartley, June 2011.

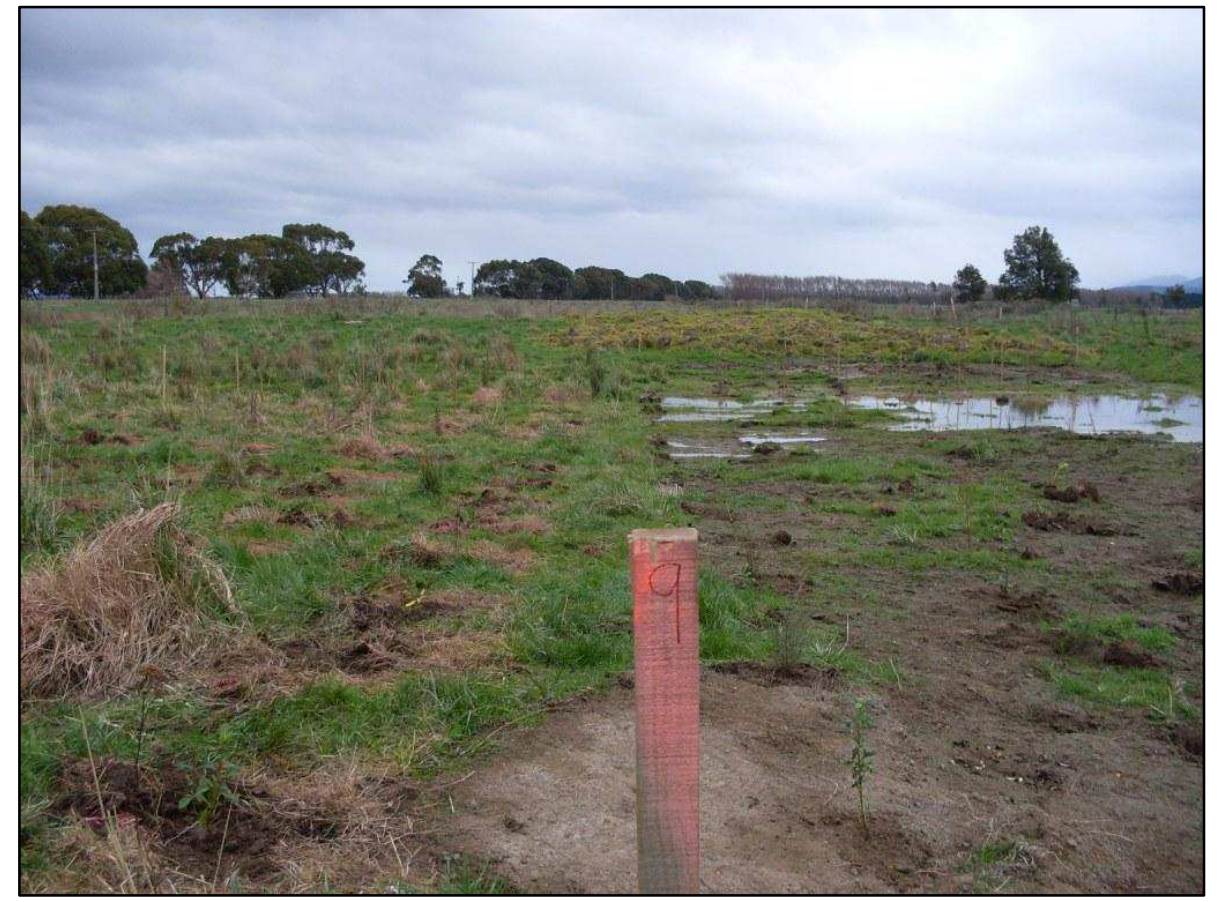

Figure 40 Wairio Wetland Stage 3, Block 9 with newly planted native saplings. Right-hand side scraped with some surface water. Left-hand side unscraped but sprayed. Photo by Dr Stephen Hartley, June 2011. 


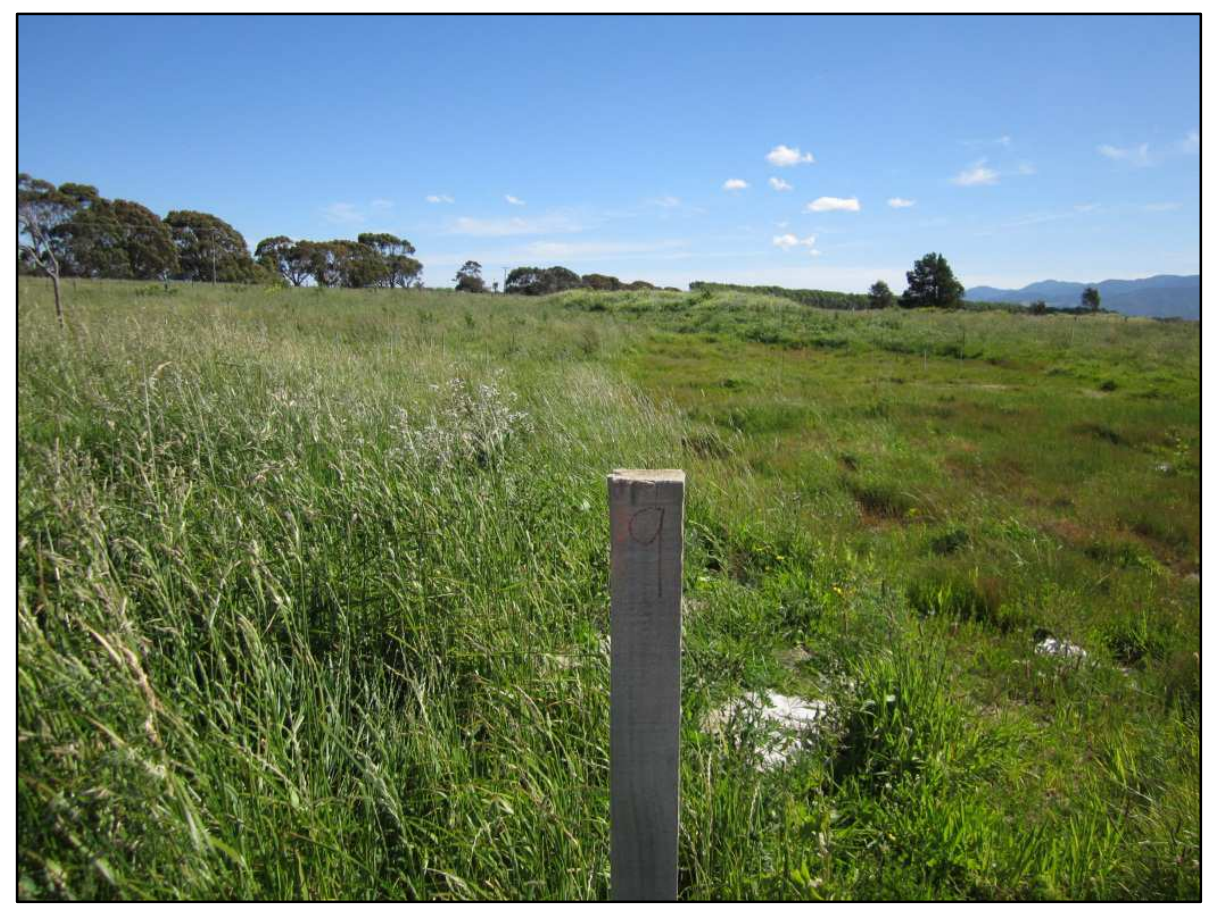

Figure 41 Wairio Wetland Stage 3, Block 9 comparison with Figure 39, 6 months later. Right-hand side scraped with some surface water. Left-hand side unscraped but sprayed. Photo by Dr Stephen Hartley, December 2011.

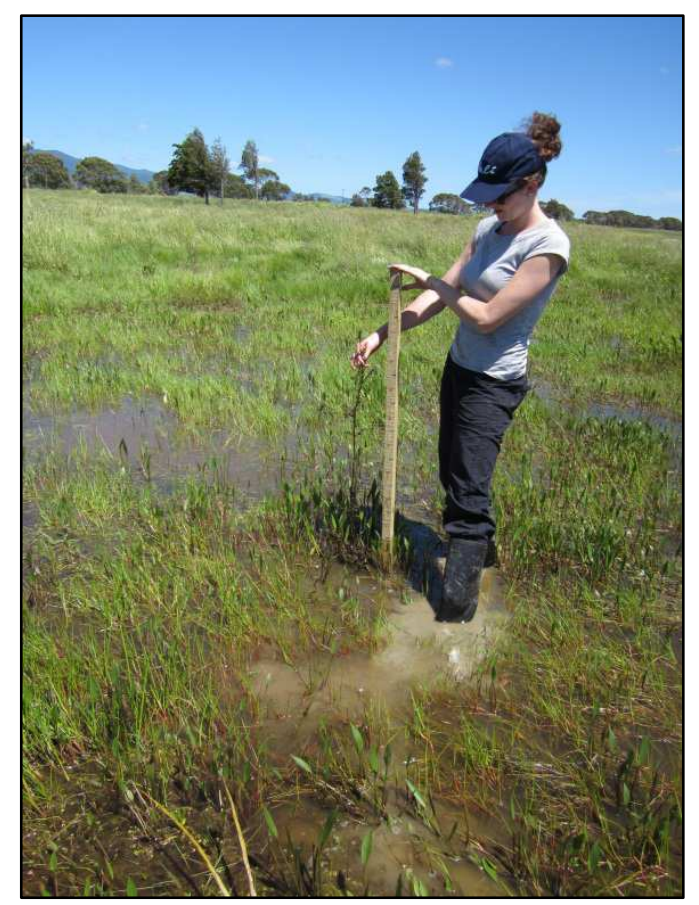

Figure 42 Wairio Wetland Stage 3, Block 9. The author measuring a $D$. dacrydioides, which is partially submerged in water. Photo by Dr Stephen Hartley, December 2011. 

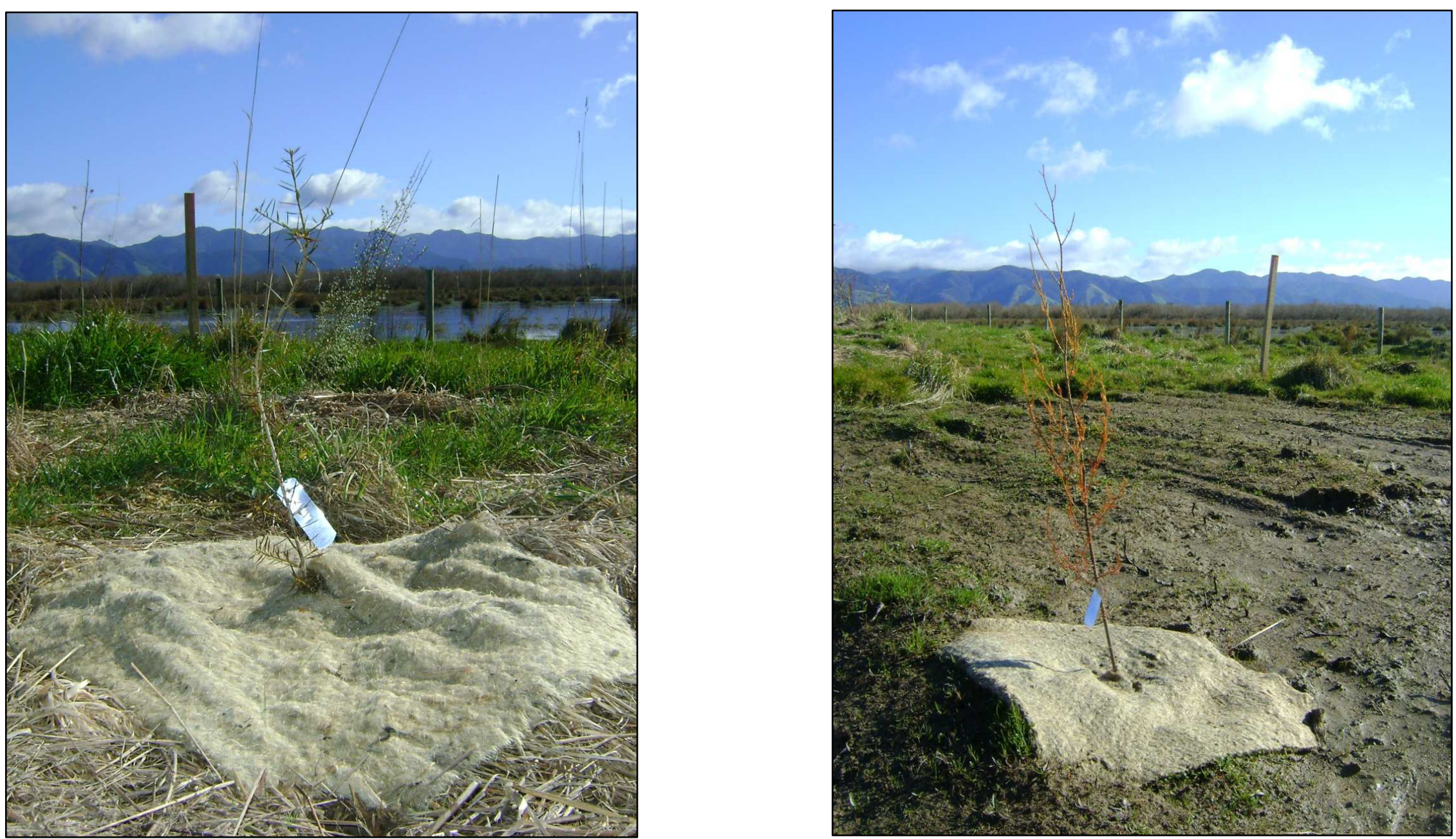

Figure 43 Wairio Wetland Stage 3, Block 7. A) P. totara planted with treatment of unscraped topsoil and weedmat. B) $D$. dacrydioides planted with treatment of scraped topsoil and weedmat. Note metal Alutags with species name and coded number attached to each focal plant. Photo by Author, August 2011. 